

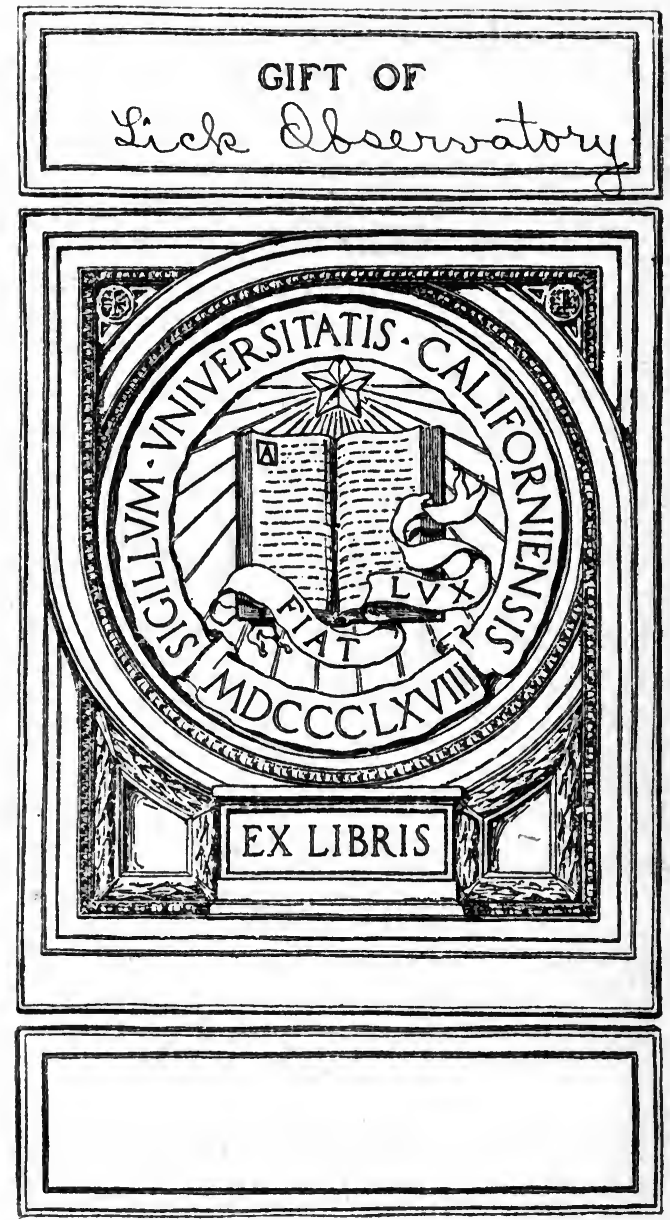


$$
\text { ri. }
$$







THE DANGERS OF MUNICIPAL TRADING 
Digitized by the Internet Archive in 2007 with funding from Microsoft Corporation 


\section{THE DANGERS OF}

\section{MUNICIPAL TRADING}

BY

\section{ROBERT P. PORTER}

DIRECTOR OF FLEVENTH U.S. CENSUS

AUTHOR OF

' COMMERCE AND INDUSTRY OF JAPAN,' 'INDUSTRIAL CUBA,' ETC.

LONDON

GEORGE ROUTLEDGE \& SONS, Limited BROADWAY HOUSE, E.C. 


$$
\begin{array}{rl}
H D & 431 \\
47 & P^{7} \\
19670
\end{array}
$$

$$
\text { sid obertem }
$$

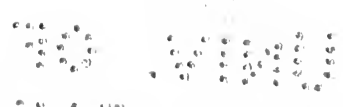




\section{PREFACE TO THE ENGLISH EDITION}

7 HIS book was written for the American public for 1 reasons set forth in the Preface to the American edition which follows, and was published by the Century Company of New York in January of this year. At the time it was written, the author did not contemplate publishing an English edition of the work, nor had he any wish to appear in the light of submitting before the English public his views on a question so well ventilated in England of late years as the merits and demerits of Municipal Trading.

The book, however, had its origin in England four years ago, when the publishing firm of Messrs Isbister and Co. invited the author to take part in a joint discussion with Mr G. Bernard Shaw on the subject of Municipal Trading in connection with their Pro and Con series of works on questions of the day which they were then publishing. The manuscripts, both of $\mathrm{Mr}$ Shaw and of the author, were duly placed in Messrs Isbister's hands, but owing to the liquidation of the firm, which took place shortly after, the contemplated volume never appeared. Mr Shaw subsequently published his part 
of the volume as a separate work, entitled The CommonSense of Municipal Trading, which hereafter has been occasionally quoted; whilst the author's unpublished contribution has been freely utilized throughout these pages.

Beyond the alteration of the title from The Dangers of Municipal Ownership to The Dangers of Municipal Trading, and the addition of Chapter XVI, 'Nationalization of Railways,' and Chapter XVII, 'Conclusions,' the present edition, though entirely reset and printed from new plates, does not substantially differ from the work published in the United States.

Pressure of other work has prevented the author from recasting the book with the special view of adapting it to appeal more directly to the English public ; but it is hoped that the cogency of the arguments have not suffered by their having been primarily addressed to American taxpayers, who are confronted with the same problems of local government as those which are now before British ratepayers.

Since the publication of the American edition the municipal elections in London and Chicago have revealed a significant reaction, which, if duly supported by those responsible for private enterprise, should lessen, if it does not remove, the dangers of Municipal Trading.

$$
\text { R. P. P. }
$$

The Three Gables,

BanbURy ROAD, OxFORD

June I, 1907 . 


\section{PREFACE TO THE AMERICAN EDITION}

THIS book discusses a question of great public 1 concern on both sides of the Atlantic. Its aim is to give a brief history of Municipal Ownership (or Trading) in Great Britain, and to set out certain serious aspects of the municipal position in that country which have arisen consequent upon an indiscriminate pursuit of the system, with a view of indicating the probable effect of the extension of a similar method of conducting public services in the United States. This method is generally known in England as 'Municipal Trading,' and throughout this volume the two terms 'Municipal Ownership' and 'Municipal Trading' should be understood to mean one and the same thing.

It has been recognized by thoughtful men that an attempt should be made to bring together, in a volume not too expansive or profound for popular reading, some of the facts and arguments used by the opponents of Municipal Trading in England. In the present volume the writer has endeavoured to meet this desire, particularly for the benefit of the man who wishes really to study the subject, but who otherwise has no alterna- 


\section{viii PREFACE TO THE AMERICAN EDITION}

tive than to seek his information in numerous scattered reports, debates, addresses, and in articles in periodicals and newspapers, many of them extremely able, all of them not easy of access except at the time of publication, and none of them complete in themselves. Literature in favour of Municipal Trading has, on the other hand, assumed of late years considerable proportions, and is distributed far and wide. In order that their trading policy may be presented to him in the best possible light, every facility is afforded to the student of Municipal Government by local authorities in Great Britain. But the defects of the system can only be found after diligent search in an infinite variety of sources. Hence the favourable impressions which some American writers have obtained of Municipal Trading in Great Britain may be accounted for by the fact that, knowing little or nothing to the contrary, they have been influenced by the persuasiveness of the local councillors and officials under whose escort they have visited municipal works, and whose glowing accounts of the undertakings have been calculated to make ready converts. The case against the trading policy is less easily ascertained. That can be best presented by the business man; but, having his own affairs to attend to, he does not generally ventilate his objections, nor is he usually available for interviews. Not so the municipal councillor or official, who is always at hand ; for, thrown on his defence by the force of objections to the system, it is his paramount concern to justify his own works to all and sundry. The object of this book, therefore, is 
to set forth that upon which the business man and the municipal official are alike silent-the former because he has other things to do-namely, the inherent defects of the whole principle of public trading.

The subject-matter of the following chapters has been based mainly upon lectures and addresses delivered by the author before various bodies-the British Association, the Society of Arts, the London School of Economics (in connection with the University of London), and the London Chamber of Commerce, as well as upon contributions to several American periodicals. In the general design of the work an attempt is made to show, in consecutive order : (I) Trading as an undesirable element in State and local government, and as a menace to progress and to society; (2) its financial unsoundness; and (3) that an examination of specific public undertakings supports the general argument.

The facts embraced within these broad divisions of the subject undoubtedly point to the dangers of government (State or Municipal) interference with industrial development, and in the usurpation by public authorities of functions which are better left to private companies and to individual enterprise. After reading the evidence presented, few will continue to regard the experiments in Municipal Trading in Great Britain as so satisfactory as some of its more enthusiastic advocates have claimed. But if, with these facts before him, the citizen who really has the interests of his country at heart still desires the extension of the system to American municipalities, with all the attendant disasters, he will at least enter upon 


\section{$\mathbf{x}$ PREFACE TO THE AMERICAN EDITION}

the experiment with his eyes open, and he will have no further ground for being misled by the contention so strenuously promulgated, that in the mother country Municipal Trading has been an unqualified success.

On the contrary, he will be aware of a condition of things which Mr Dixon H. Davies, to whom proofs of the book were submitted, so admirably epitomizes in a letter to the author that his words may be quoted here as serving for a comprehensive synopsis of the book :

'The fact is,' writes Mr Davies, 'that supporters of the trading policy of Great Britain have forsaken the standard of industrial and financial success, and have adopted instead the shelter of legalized monopoly and compulsory subsidy. They have forsaken the service of the public at large, and are catering for any section of the community, however small, who may have influence enough to help themselves to a facility such as telephones, or parcels carriage, or hydraulic power, by the aid of the public purse. They have forsaken the idea of democracy; their funds are largely derived by taxing those who are not represented, for in many cases the larger portion of the assessable property is owned by companies and others who have no votes at all. They have thrown overboard the standard of justice, for there is no justice in raising a large sum by taxing, for instance, railway property in order to establish a carrying business which can have no purpose except to reduce the just railway earnings. They have forsaken the idea of local self-government, for there is nothing local in the bureaucratic ring which whips the member 
for a Scotch borough to vote against an electric-power scheme for Ireland. There is nothing autonomous in placing the community in bonds of debt to outside capitalists who are placed in the position to dictate the raising of rates in the borough for generations ahead. They have raised the cost of all production by depriving the industries of cheap power facilities which, but for their interference, they would long ago have had. They have raised rents by discouraging the building of working-class houses by private persons who hesitate to compete with the rate-provided houses of the municipality. They have lowered wages by draining the capital resources of the country into borough treasuries, thus both diminishing employment by creating an artificial scarcity of capital in the industries, and reducing the share of labour by increasing the price of money. They have destroyed the independence of thousands of workers by turning them into municipal officials. They have lowered the function of the capitalist by relieving him of responsibility, and consequently of the necessity for bold and shrewd adventure. Finally, they have abandoned the idea of the greatest good of the greatest number, and zealously promoted the greatest good of the money-lender.'

It is a pleasure to acknowledge the cordial help afforded by authorities on the subject both in Great Britain and on the Continent. In this connection it may be mentioned that the writer has had the advantage of studying the official, technical, and legal sides of the question in investigations made at various times for several large 


\section{xii PREFACE TO THE AMERICAN EDITION}

undertakings in the United States engaged in streetrailway, gas, and electric-lighting operations. These inquiries were made for the purpose of ascertaining the exact relations between such public works and the municipal authorities in many of the principal cities of Europe; and upon the data obtained in some of these investigations the conclusions hereinafter set forth have been in part based.

R. P. P.

The Three Gables,

Banbury Road, Oxford,

January I, 1907. 


\section{CONTEN T S}

CHAPTER

PAGE

I. MUNICIPAL TRADING AS A PUBLIC QUESTION - I

II. THE GENERAL CASE AGAINST MUNICIPAL TRADING - 2 I

III. THE DESTRUCTION OF INDIVIDUALITY-RUSSIA AS

AN OBJECT-LESSON $\quad-\quad$ - $\quad-\quad$ - $\quad-44$

IV. THE PUBLIC WORKS POLICY OF AUSTRALASIA - 56

V. THE REFLECTIONS OF OTHER MINDS - - - 78

VI. A POWER TO BE RECKONED WITH - $\quad$ - $\quad$ - 89

VII. BRITISH LOCAL AUTHORITIES - _ - - - $\quad$ - 102

VIII. THE BURDEN OF OWNERSHIP OBLIGATIONS - - II2

IX. THE WORLD'S GREATEST SPENDTHRIFT - - I3I

X. SOLVENCY OF CITIES - - - * - - I53

XI. DELUSIVE DEMONSTRATIONS OF PROFITS - - I67

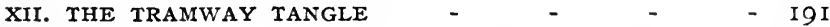

XIII. THE STRANGLING OF THE ELECTRICAL INDUSTRY - 2 II

XIV. FAILURE OF TELEPHONES UNDER STATE OR MUNICIPAL

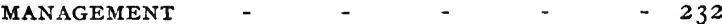

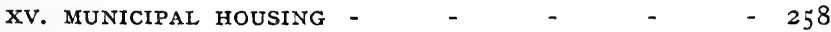

XVI. NATIONALIZATION OF RAILWAYS - - - - $\quad 285$

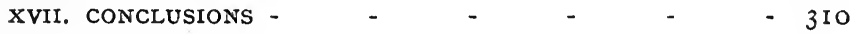

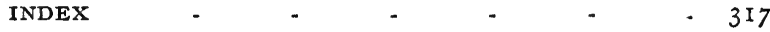




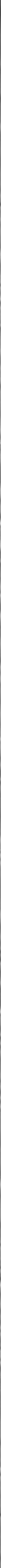




\section{THE DANGERS \\ OF MUNICIPAL TRADING}

\section{CHAPTER I}

MUNICIPAL TRADING AS A PUBLIC QUESTION

THE extension of the functions of municipal govern1 ment in the acquisition and operation of commercial undertakings is just now attracting considerable public attention, both in Great Britain and America. This form of expansion may be aptly termed exotic, in that it has no proper relationship to the duties for the performance of which governing bodies were expressly created. On the false plea that certain business enterprises are public works, and as such should be publicly owned and managed, municipal authorities have inaugurated a policy known as 'Municipal Trading ' on one side of the Atlantic, and 'Municipal Ownership' on the other, the tendency of which is being studied with considerable interest by economists, politicians, and, in fact, by all concerned in the prosperity and welfare of the two countries.

The question, by reason of the rapid growth of urban population during the last generation, is one of great and ever-increasing magnitude, and to treat it as fully 
and impartially as its importance demands is not an easy task.

Looking twenty-seven years back (I880), when the writer was commissioned by General Francis A. Walker, the then director of the United States Census, to investigate the methods of municipal government in Great Britain, he was struck with the fact that at that time this phase of local administration was not present as an active issue. There was no swollen municipal debt, nor any burdensome taxation to be attributed to this cause. The instructions from the Census Bureau embraced an inquiry into the financial aspects of British local government, but as municipal trading had not then assumed serious proportions, the suggestions in respect to such trading were silent. Equally silent on the subject was the purport of the interviews obtained with municipal authorities in Great Britain; so that the report subsequently made contained no reference to the existence of 'trading' in this country. As a matter of history, however, it was then (outside municipal watersupply) in a chrysalis stage, wherein it remained more or less for quite a decade before it emerged as a contentious element in municipal politics.

In Birmingham, where the writer called on Mr Chamberlain, he was impressed with the enterprise of the municipal authorities. All manner of insanitary properties-slums and rookeries, and congested, badly-laid streets and alleys-were demolished, and on the clearances made new thoroughfares and modern tenements and houses were built. Similar attention was given to 
a better water-supply, improved sewerage, and the provision of baths, wash-houses, and public recreation grounds. The condition of other British towns at that time-Liverpool, Manchester, Leeds, Glasgow, Nottingham, and Bradford-also bore painful witness to the existence of the then common corporate vice of the poorer districts being allowed to remain a harbouring ground for physical and moral disease, and their authorities were likewise making creditable efforts to remove the reproach.

Hence there could be nothing but praise by the author in his report on returning to America for the direction which municipal work in Great Britain was then taking. It bore a similarity to civic enterprise in American cities, with the important difference that, while British cities were renovating districts, American cities were creating new ones. The latter had no rookeries to clear; they had to their hand virgin ground, which spread out round about their small centre - generally a straggling village, soon to expand to a considerable city by rapid stakings-out of new thoroughfares. These developments proceeded from the revival of the country after the close of the Civil War. But large and absorbing as they were, they did not appear to provide a sufficient outlet for new-born civic energies. Nothing would content the citizens but the simultaneous and equally vigorous pursuit of a policy which had not then appeared on the municipal horizon in Great Britain. Waterworks were built, avenues and parks were laid out, and county and municipal credit was indiscrimi- 


\section{THE DANGERS OF MUNICIPAL TRADING}

nately loaned to railroads. The consequence of all this rash enterprise, undertaken in addition to the legitimate work of laying sewerage systems and necessary new streets, was soon manifest. There came then into existence an accumulation of indebtedness which almost made the taxpayers bankrupt. Many towns could only rescue themselves from such a plight by a resort to the expedient of 'repudiation '- that is, they boldly defaulted. British municipalities, on the other hand, had confined their policy of reform to street improvements and to sanitary amelioration by the clearance of unhealthy areas. Thus they had not to face such an ignominious incident in the pursuit of their fiscal programme, though the imprudent way in which they have since followed the example of American cities in this and in other directions can only mean that the future has in store for them a similar fate.

From the foregoing, therefore, it will be seen that municipal enterprise of American and British cities at that time fundamentally differed. On the one hand, the former were nearly ruined by pushing their activities too far (such as inviting the railways to come to them by paying them large sums as subsidies and by endorsing their bonds), whilst on the other, the latter had kept their policy of civic development within bounds.

The consequences to American cities of recklessly following a policy of acquisition, and of loaning their credit to private enterprise, was so disastrous that they made a volte face, and until recently have kept municipal ownership and operation at arm's length. The wisdom 
of this determination was soon reflected in the marked reduction of their debts and taxation which followed. But just as American cities relinquished the trading field to its rightful exploiter-private enterpriseBritish cities appear to have entered it. Whilst, as we have seen, little trace of the existence of municipal trading in the form by which it is now known was revealed in the course of investigations made in Great Britain in I880, symptoms of it were undoubtedly vaguely present here and there. Glasgow apparently had early coquetted with the idea; but the most concrete form which its development took was in Birmingham, between 1874 and 1876 , that is, during the mayoralty of Mr Joseph Chamberlain, the inspirer of the active municipal life for which that city was then and has since been notable. It was that eminent statesman who secured the purchase of the gas-works by the municipality. A few years later they had to safeguard their new property, for electricity appeared on the scene as a rival to gas, which brought about (also through $\mathrm{Mr}$ Chamberlain's agency) the passing of theElectric Lighting Act of I882. Thus was begun the Parliamentary protection of municipalities, followed by other Acts, by the aid of which local authorities have since spread out their monopolies far and wide. Mr Chamberlain may therefore be regarded as the father of the new municipalism. It is true that, so far as municipal tramways were concerned, the way was opened for them by the Tramways Act of 1870 , but the effect of its famous expropriation clause was not generally felt until the nineties. 
The developments which followed this action of the Birmingham municipality soon attracted the attention of the Socialists. The propaganda of the Fabian Society (the offspring of Mr George Bernard Shaw) had been spread broadcast, and there is no doubt that it indirectly urged British corporations to redeem portions of their cities from the stigma of remaining blots on the face of the civilized world. The success which attended the praiseworthy efforts of the Fabians in this direction encouraged them to look to the municipalities for the realization of their desires, especially when they discovered the existence of municipal ambitions which more or less fell into line with their principles. Like their confrères in Germany and elsewhere, the Socialists sought the firmest platform from which to propagate their views. They made no impression upon Parliamentary constituents; their candidates cut poor figures at elections everywhere. At that time, therefore, they abandoned Parliament as the arena in which they could promulgate their collectivist theories with any effect. They saw they could enter their wedge with greater ease through the municipalities-who, by the way, appear to be strangely blind to the stimulus the spread of Socialistic doctrines had on the inception of their policy. Municipal trading candidates-model Conservatives in politics many of them-have secured election through the votes of electors who were won over to Socialism by the attractive pictures presented to them of all property becoming vested in the people, of which municipal institutions were a foretaste. So that, to the 
extent to which there was any active campaign in favour of the new municipal policy, it came from the Socialists. When the Times a few years later (I902), in the series of articles it published on the question, recognized that the aims of the municipalities and the Socialists were identical, and boldly christened the whole movement 'Municipal Socialism ' pure and simple, it brought forth angry protests from the municipalities; but the designation was none the less true.

Before the Times, with such telling effect, called attention to the dangerous spread of Municipal Socialism, other criticism, with the same object, had been drawn to the question. In fact, the considerable literature which now exists on municipal trading really began to grow at the close of the eighties. During this period the movement appears to have developed quietly without publicists discovering what it really meant. But its extent and ramifications duly indicated the anti-social courses whither it led all too clearly; and in 1899 it fell to $\mathrm{Mr}$ Dixon H. Davies, of the Chesterfield Chamber of Commerce (now solicitor to the Great Central Railway Company) to sound the alarm in a paper he read before the Society of Arts, with the then Attorney-General (now Lord Alverstone, Lord Chief Justice of England) in the chair. Moreover, public opinion in the Metropolis at about this time revolted against the extravagant policy of the London County Council. The electorate, however, had to wait for the polls of I895 before they could express their disapproval, when they deprived the Progressive party of their majority. The lavish policy of 
the London County Council at this period really gave the impetus to co-ordinating an unorganized disapproval of municipal trading into a strong body of opposition. The London Chamber of Commerce, long before this, had formed a Municipal Trading Committee, and had risked a battle with the municipal traders in forcing the matter on the attention of Parliament. In this they succeeded in I900, when the serious increase in local indebtedness, taxation, and assessments, directly traceable to the municipalities carrying on industrial undertakings at a loss, came before the House of Commons, and a joint committee of both Houses was formed to inquire into the whole question. The investigation unfortunately proved too extensive and complex for this committee to make any report upon the merits or otherwise of Municipal Trading. All they did was to wind up their work by a recommendation of reappointment in the next session of Parliament. The close of the session precipitated this abrupt conclusion to the committee's inquiries, and it was not reappointed during the remainder of that Parliament. A General Election almost immediately followed. But as the polls did not alter the political complexion of the new House of Commons, there was no reason why this committee should not have been at once reappointed, nor, indeed, why it did not reassemble in the final session preceding the dissolution in I900. It was generally understood that the municipal members persuaded the Government to shelve the investigation.

Not until I903 did Parliament take any further action. 
Then another joint committee was appointed, to continue the inquiry begun by the I90o committee. But all they did was to report on the proper form in which municipal accounts should be prepared and published. This limitation to their investigations, of course, merely touched the fringe of the question; so that the committee's due recommendations advocating the abolition of the present system of municipal audits, and the appointment of independent auditors, were about as ineffective as they well could be. The committee's deliberations, indeed, were nearly as abortive as those of its predecessor. The members were apparently conscilus of the inadequacy of their labours, for they ventured the somewhat colourless opinion that 'it would be advisable to continue investigations into other branches of Municipal Trading in a future session of Parliament.'

Not Parliament, but the outside public, acted upon that opinion. The subject was taken up unremittingly by public men, and opposition to reckless municipal trading schemes was organized. Following the appointment of the first joint committee, the Press turned its searchlight upon the municipalities, notably the Times, by its celebrated articles on 'Municipal Socialism' before referred to. A symposium in the pages of Traction and Transmission, where a number of public men qualified to speak on the subject expressed their views, also attracted attention. The preponderance of opinion which thus found ventilation through these and other public channels was strongly in favour of placing some check on municipal aggrandizement. 
The friction with private enterprise became so marked that in I902 the Industrial Freedom League, ' an association formed to free private enterprise from undue interference and from rate-aided competition', was established, and has since carried on active propaganda throughout the country. The League is consequently the target of constant bitter attacks by the municipal organs. In the Metropolis what may be termed the ' unsteadiness' of the London County and Borough Councils alike also called forth a similar campaign from a long-established association-the London Municipal Society. This body was compelled to exercise a vigilance regarding the expenditure of public money beyond the object for which it was originally formed, which had wholly to do with safeguarding the ratepayers' interests in ordinary municipal administration. Though these two organizations did not succeed until lately in thwarting municipal Socialistic schemes, they at least forced local authorities to tread with more wariness than if such antagonism had not been marshalled against them. More than that, their campaign had the effect of stimulating the municipal party to form the Association of Municipal Corporations and Town Clerks-now a very powerful body. Their coercion of members of Parliament to vote against private schemes which may adversely affect municipal monopolies is notorious. Such influence could only be wielded by the Association by first winning over to their banner that large unstable class of the electorate (including municipal employés) whose political opinions are nebulous, and who are easily impressed 
with official municipal utterances, and with this voting power at their back they have only to indicate to a member that his seat will be in jeopardy at the next election if he does not heed their bidding.

The heightened hostility thus engendered between municipalities and private traders, added to the unjust treatment and repressive measures which the latter had to suffer, more particularly in relation to tramway extensions, attracted attention from another quarter. This was the Royal Commission on London Traffic, who made some observations in the first volume of their report, issued in I905, which bear repetition. In contrast with the British trading system, they viewed favourably the method under which the street railways of New York and Boston were built. In their case the operating companies obtained the necessary capital for construction from the respective municipalities at a higher rate of interest than that at which the latter raised the necessary loans for the purpose on the credit of the cities. The difference between the rate of interest paid to the bondholders by the cities and that paid by the contracting companies to the cities enables the debt created on account of street railway construction to be paid off by the expiration of the franchise, when the tracks and road-bed (but not the equipment) come into the hands of the cities practically free of cost. The companies meantime undertake all risks attending the construction of the lines and of operation. Though the question of municipal ownership was not a part of their instruction, the London Traffic Com- 


\section{I2 THE DANGERS OF MUNICIPAL TRADING}

mission expressed the opinion that the relations existing between the municipalities and private enterprise demanded inquiry.

But it would seem from the present outlook for Municipal Trading that, so far as Parliament is concerned, it will proceed on its way unchecked. Such at least is to be gathered from the declarations of at least two members of the Cabinet, the Prime Minister and the President of the Local Government Board ( $\mathrm{Mr}$ John Burns), taken in conjunction with the fact that the Government majority is prepared to vote for any legislation the purpose of which is to give the municipalities more and more freedom of action. On the other hand, it is by no means certain that the sympathies of the Prime Minister and Mr Burns with municipal ambitions are shared by their colleagues in the Cabinet. British private enterprise, therefore, has reason to hope that a common defect of Radical Governments-a lack of solidarity-will stand in the way of the municipalities obtaining from Parliament all the further powers they desire.

So far we have briefly traced the modern tendencies of the movement in both countries correlatively, because its progress in Great Britain has more or less set the pace to the public attention accorded to it in the United States. For this reason it will be convenient now to proceed to survey, in the same relation, the stages through which the question has passed as a debatable proposition in the latter country.

The growth of the movement in Great Britain in the 
eighties drew Dr Albert Shaw, now editor of the American Review of Reviews, and then attached to a Minneapolis journal, to that country, and he wrote a series of letters on the subject, which were published in the paper he represented, and afterwards in book-form. His work was the forerunner of the miscellaneous literature which has since appeared in America on the subject. At that period Dr Shaw saw what I saw and have acknowledged, and what impartial critics (with whom he must be ranked) will admit - that the best side of municipal enterprise in Great Britain was then to be seen. That cannot be said now. Indeed, it is probable that were Dr Shaw to visit Great Britain with a like purpose at the present time, he would have grounds for revising some of his early statements made in approval of municipal work in England. But time has left unaltered one important consideration which even then would not escape that brilliant publicist, namely, that comparisons between European and American cities for the purpose of elucidating municipal problems were of little value. The fact remains true to-day.

However favourably municipal work had impressed Dr Shaw in England, it did not convert him to an advocacy of Municipal Ownership for New York. Before a committee formed by the Legislature of that State on Municipal Ownership, he testified that he had never thought of ownership as a remedy. Dr Shaw's then views are to be emphasized to show that an approval of English municipal methods of trading does not induce a man, broad-minded enough to grasp the 
points of difference in the local government administration of the two countries, to recommend their adoption by American cities.

The New York committee referred to seemed to have had no difficulty in coming to a conclusion upon the question they had been formed to investigate. Here is a portion of the text of the final paragraph of their report :

'As an abstract proposition, we believe that no Government, either national, state or municipal, should embark in a business that can be as well conducted by private enterprise. The reverse of this proposition, carried out to a logical conclusion, would put all business enterprises under governmental management and control, and leave to no citizen any hope, ambition, or aspiration beyond that of seeking an official position that affords a meagre existence.'

It may be that this conclusion had the effect of silencing for some time the agitation for the promotion of the ownership and operation of public works in the United States; at any rate, in that country, as in England, the question smouldered for nearly a decade.

The year I897 found the State of Massachusetts seeking information with regard to the relations of cities and towns with street railway companies. The question had been raised in that State as to the desirability of the companies paying a special franchise tax or a fixed rental to the municipalities, in addition to the ordinary tax levy. A committee was appointed by Governor Wolcott, and it was the writer's privilege to lay before 
them the result of the further inquiries made in 1897 into the position of the municipal tramway systems of Great Britain. The writer's testimony was to the effect that the results of such working were not to be accepted as a guide for other countries to follow, and this, no doubt, led the Massachusetts committee to conclusions which, in effect, were similar to those of the New York committee. At any rate, they held that neither partial municipalization (ownership, but not operation) nor complete municipalization (ownership and operation) of the street railways of Massachusetts was desirable in the uncertain experimental stage which municipal control of such services had then reached; nor could they recommend that the State laws should be amended in order to exact a special franchise tax from the companies in addition to the ordinary taxes levied on the assessment value of their properties. They deemed the existing system in Massachusetts satisfactory.

We must turn to Chicago for the next important development of the movement in the United States; this brings us to the spring of I905, when the citizens at the municipal election declared in favour of the complete municipalization of the street railways. The Mayor-elect, jubilant over this expression of the popular will, cabled to Mr Dalrymple, the general manager of the Glasgow municipal tramways, to come to Chicago to confer with him as to the best means of carrying out the voters' mandate. The invitation was accepted; but Mr Dalrymple, though committed to municipal trading by the nature of his employment, gave up the 
task of adviser, declaring in effect that what was possible and successful in Glasgow was not feasible in Chicago. Here we have a striking confirmation of the point mentioned above regarding the uselessness of English experience as a guide to American cities. Perhaps the futility of the consultations with Mr Dalrymple had made some impression on the minds of the citizens. Certainly the result of the referendum to the Chicago citizens submitted twelve months later (in April, I906) showed that they were not wholly of the same mind as in I905. Three propositions were put before them: (I) To sanction the borrowing of $£ I 5,000,000$ for the purchase, construction and equipment of the street railways; (2) That the city proceed without delay to operate them; and (3) That the city should not do so. A small majority was given in favour of the first proposition. Many voters not sympathetic with ownership felt compelled, it is said, to support it because of the unsatisfactory street railway services they had had to suffer for the past ten years. The second proposal was defeated, and the third carried by a small majority. To extricate the meaning hidden in these results, it would seem that the voting on the third proposal did not carry any weight, and is not binding. There remain, therefore, the first and second proposals, which show that at that time the city of Chicago was in favour of municipal ownership, but not of municipal operation.

Again, the question was submitted to the people of Chicago in April, I907, in what has been described as a 'fair and square fight' as to municipal ownership of 


\section{A PUBLIC QUESTION}

street railways. It resulted in a complete reversal of popular feeling on the subject, and $\mathrm{Mr}$ Dunne, who two years ago was elected on a municipal ownership platform, has now been defeated. Commenting upon this victory, the Times of April 6, I907, says :

' There seems to be no escape from the conclusion that municipal ownership lost its charms when it came to be closely examined, and had to pass from the region of vague general aspirations to that of concrete business propositions. Chicago is admitted by all to be in the frying-pan, but she declines to jump into the fire. The existing state of things is bad, so bad that two years ago the city was hot for the municipal experıment ; yet, now that two years have been spent in realizing what the experiment means and promises, the people will have nothing to do with it. That revulsion of feeling in a great community is certainly very remarkable, especially when we remember how long the opinions now discarded had been growing and consolidating before they reached victory two years ago. It is doubly remarkable when we recall the fact that Chicago may be regarded as the centre of American Socialism, and, therefore, as the place where, above all others, a signal victory for municipal ownership might have been expected to prove final and irreversible.'

The bait of municipal ownership and operation is now dangled before the people of the United States in a way which wins many over, entirely on sentimental grounds. They are not sensible of its practical and economic 
aspects-the accretion of indebtedness it involves, the expansion of the tax-levy and assessment values of their properties, the bureaucratic power of officialism it creates, and the temptation it offers for the entry of many more corrupting influences into municipal work than those which unhappily exist already. For example, nothing, in my opinion, could be more one-sided and misleading than the report on 'Municipal Ownership in Great Britain,' by Dr F. C. Howe, contained in the bulletin of the Bureau of Labour for January, Igo6. Whilst the question is undoubtedly ripening in the public mind in the United States, a true knowledge and understanding of its merits are carefully concealed from the electorate.

A desirable move in the direction of obtaining some definite information on the subject was recently made by the National Civic Federation when they sent a committee of delegates to Europe to investigate the latest phases of municipalization, complete or partial. The delegates went over much the same ground as that which I surveyed twenty-five years ago, and found fully grown in many British cities what during my investigations was then merely a tendency, or did not exist at all. Writing before their report has been made public, and without speculating upon the nature of their conclusions, the present position warrants the observation, as much as it did a decade ago, that however much the external attractions of British municipally owned institutions may win the approval of visitors from other countries, the desirability of transplanting those systems 


\section{A PUBLIC QUESTION}

into American soil remains as thorny a question to decide as ever. It is, indeed, evident from the failure of Chicago to obtain guidance from Glasgow that an understanding of European methods does not seem helpful to a settlement of the question in America.

The chronology of events turning on the ownership question closes, so far as this recital is concerned, with the New York governorship election in November of I906, which ended in the defeat of Mr Hearst, the municipal ownership candidate. But it is only fair to say that his defeat was a personal one, not a defeat of the principles he professed. Indeed, the ownership question, whilst a main plank of the democratic platform, was overshadowed by the anti-trust issue, which in its turn seemed to have become lost in a descent to mere personalities which characterized the conduct of the campaign as it neared its close. The election, indeed, was more a contest of personalities than of principles. The ownership question was wholly in the background; but it is too active an issue to remain so. for long, and it is bound to revive with renewed force. Probably the next New York mayoral election, if the candidates nominated conduct their canvassing without the introduction of personal attacks on each other hailing from all quarters, will give the New York citizens the opportunity of expressing a definite opinion on the question.

The restraint on American cities lies in the State constitutional limitations of debt enacted by organic law for the protection of the taxpayers, beyond which they cannot go in order to raise money for trading purposes. 
The National Government, however, has no control over them, as Parliament has over British municipalities through the Board of Trade or the Local Government Board. General control over municipalities is certainly exercised by the State Legislature, but the laws this body enacts relating to municipal powers are not as a rule specific. A law is not usually passed which applies to a particular city and which approves the spending of money for any specific scheme its council desires to undertake, as is the case with British cities which obtain Parliament's sanction to their individual private Bills empowering them to pursue their ownership policy. On the contrary, American laws embrace groups of cities denominated according to their populations, but within the limitation of the general State laws the cities have no need to apply either to the National or to the State Legislatures for permission to undertake ownership works. They obtain their mandate solely by a referendum to the citizens; and it speaks much for their prudence that they have so little exercised their option to the extent their freedom from superior authority gives them. 


\section{CHAPTER II}

THE GENERAL CASE AGAINST MUNICIPAL TRADING

THE position of Municipal Trading in both countries, 1 especially in Great Britain, demands that the case against it should be submitted, for the benefit of their taxpayers, as strongly as possible. Industrial and commercial speculation with money raised by taxation, viewed from whatever standpoint, and called by whatever name, is, in my opinion, inconsistent with the sound and just principles of government. Such trading with the public credit, whether State or municipal, must of necessity lead to stupendous financial liabilities, add to the burden of the rates, weaken municipal credit, bring about inequality of taxation, interfere with the natural laws of trade, check industrial and scientific progress, stop invention, discourage individual effort, destroy foreign trade, establish an army of officials, breed corruption, create an aristocracy of labour, demoralize the voter, and ultimately make Socialistic communities of towns and cities.

The question of allocating existing public funds, or raising capital on the credit of the city, has frequently been the subject of legal investigation in the United 
States, and has been declared contrary to the constitutional laws of several States, notably Massachusetts. Here is an extract from the Constitution of that State : 'In the government of this Commonwealth the legislative department shall never exercise the executive or judiciary functions or either of them ; the executive shall never exercise the legislative or judiciary powers or either of them; the judiciary shall never exercise the legislative or executive powers or either of them, to the end that it may be a government of laws and not of men.' Mr Dixon H. Davies ${ }^{1}$ has pointed out that the Massachusetts State Constitution is supposed to be founded on English Common Law. If that be so, then the modern direction of local legislation in Great Britain -interference with the private individual (or 'government of men '), show that British municipal authorities have become blind to the spirit of the Common Law which alone has made good government in Great Britain possible.

The Supreme Court of Massachusetts, in view of the above clause, has handed down four opinions adverse to the whole principle and policy of public trading. The point raised was whether a city or town in that State could, within its constitutional powers, buy and sell wood and coal for the benefit of its citizens. To the several forms in which this question was presented to the Court the answer was an emphatic and unconditional negative. The Court was divided on the ques-

1 Before the British Incorporated Law Society at Manchester, Ig06 (see Proceedings). 
tion whether, in time of emergency, a municipality might be justified in buying fuel, Joseph-like, wholesale, and selling it retail, even though such trading might be outside its constitutional rights. Judge Loring, however, was not content to leave the matter open even to this extent; he filed an opinion to the effect that no emergency can make constitutional an unconstitutional act. In Great Britain there is not even an emergency to justify such a proceeding. The ground the Court took for deciding generally against the proposition of municipal fuel-yards was that the Constitution did not contemplate empowering municipalities to raise money by taxation for commercial purposes. The line of argument sustains an obvious interpretation of the fundamental law, and would seem to apply with equal force to the municipal ownership and operation of street railways, gas-works, and nearly all forms of public works.

In the well-known case of Detroit, it will be remembered that the Supreme Court decided that, under the existing Constitution of the State of Michigan, the city could not take over the street railways. State Constitutions, it is true, can be altered, and, therefore, to pursue the argument that they afford an insurmountable barrier to municipal aspirations invites the rejoinder that they are human enactments, framed to fit the conditions of a progressive country like the United States, and as such can be made as rigid or as elastic as the people choose. But if they are to be regarded as unalterable, I admit that they tend to become (and 


\section{THE DANGERS OF MUNICIPAL TRADING}

in some cases perhaps are) effete, and an obstacle to State progress. The discontent with the vetoes and restraints laid down by the constitutional laws of many States no doubt has its source in this belief.

However just or otherwise may be that view, it cannot be questioned that any amendment of State constitutional laws, intended to break down the healthy check on the growth of municipal debt and on the power of cities to employ public funds beyond the objects of government, opens the door to the entry of abuses which ownership sentimentalists little realize. In private hands the loaves and fishes are beyond reach; in public hands they are not. By such a change, in other words, the public funds, disbursed by enlightened cities prepared to buy anything or everything, useful or useless (as it may well come to be), has to face the danger of being made the objective of all manner of men of sentiment and men of straw (convertible terms often), who are ready to espouse the municipal ownership cause solely for political if not for personal gain. Even to legitimate traders, the prospect offered of driving a good bargain with a municipality run on ownership lines is corrupting. As an instance of private traders playing into the hands of a municipality for their own gain may be cited the abortive transaction, already referred to, which the city of Detroit made with a company, who sold the street railways to the city for a large sum, and had to take them back on the finding of the Supreme Court that the city had no power to buy.

A friend of the author, Mr Bemis, of Cleveland, takes 
exception to these statements because subsequently the value of the property has increased, and the city would have ultimately secured a good bargain. But suppose we grant this, the case is not altered, for the increase in value of the purchase can always be provided for in a terminable lease granted by the city for the use of the streets, which at the end of the period-say of twenty-five years-can be renewed on better terms for the city.

Enlarged freedom to American cities for the purpose of acquiring properties does not, however, stop at attracting the wolves. State supervision and forced reductions of fares of street railways, and of gas, electric, and water charges (where these services are privately operated), may force legitimate private enterprise to a complete change of attitude toward municipalities. It would be a case of ceasing to contest on an unequal issue. But it would not mean compromise. It would rather mean that the municipalities, in their ardour to control such undertakings, would indirectly influence private companies to unload their enterprises on to them at a high price, rather than continue to operate under restrictive conditions which reduce their profit to a minimum. In such circumstances the position is conceivable that it would be more advantageous for them to sell than to retain their properties. In this way one can imagine American taxpayers saddled with a heavy weight of enterprises, purchased at exorbitant figures as a penalty for sanctioning an alteration in State Constitutions by which municipalities are afforded such a 


\section{6}

THE DANGERS OF MUNICIPAL TRADING

license to traffic with public funds. Private companies, if they are not to be allowed to conduct their businesses except under vexatious and intolerable conditions, naturally will only consent to be suppressed by municipal absorption at a compensation commensurate with the value they place upon the ultimate capacity of their concerns, to which they are unable to develop them through such restrictions.

The municipalities, on the other hand, will not be blind to the object of traders who desire to sell out. One can predict many wranglings as to the price to be paid. In Great Britain there is more than one example of a municipality emerging considerably worsened in availing itself of its statutory power to expropriate. The case of the electric supply of Marylebone, in London, is an illustration. Some years ago the electric lighting of the borough was in the hands of a private company - the Metropolitan Electric Supply-whom the borough authorities approached, under the Metropolitan Lighting Act (without giving the ratepayers an inkling of their proceedings), and required the sale to them of the enterprise. The company offered to accept the sum of $£ 900,000$, but the municipality demurred to this figure, went to arbitration over the matter, spent some $£ 60,000$ in law costs, and was finally called upon to pay over $£ I, 200,000$ to the company. Here, at the very start, the municipal council saddled the ratepayers with an absolutely unnecessary charge of $£ 300,000$, on every penny of which interest and sinking fund charges have to be paid. This is a case where British munici- 
palities, in haggling terms with private companies, overlook the unpleasant fact that the law, when requisitioned, is neither a respecter of men nor of municipalities. But to whitewash their ineptitude, they naively defend themselves by saying that the outgoing companies have been 'generously treated.' Taxpayers, as business men, would probably acknowledge that when the life of a business is cut short as it nears or when it has reached its prime, such an end demands, in common fairness, that municipal expropriation should be accompanied by adequate compensation. But as that compensation adds to their tax-levy and their assessment by raising the local indebtedness, they may be driven to shut their eyes to the justice of the case, and anathematize the evil day when local governments became bitten with the craze to do everything but mind their own business.

It is not municipalities only, but States also, which, once committed to a policy of acquisition, are apt indirectly to encourage private companies to humour such governmental weakness to the top of their bent. The acquisitiveness of the one for private property fires the acquisitiveness of the other for public cash. The State purchase of the telegraphs in Great Britain in I870, when an enormous sum was paid by the Government to buy out the companies, is an instance of the willingness of private enterprise to be extinguished if the purchaser lays himself open to accept onerous terms. The British Government found too late that the telegraph system it aspired to possess was, in their hands, clogged at the 
start by annual commitments in respect of the enormous loans they had to raise in order to effect the purchase, which year by year more than absorbed the profits. Such is the case with the Government telegraphs of Great Britain. While it is true that the institution of sixpenny telegrams, and the greater use of the telephone, in part account for the annual losses their working shows, the main cause for their failure as a 'reproductive undertaking' is the success of the outgoing party bleeding the incoming party to the uttermost farthing. In justice to those who have administered the practical operations within the British Post Office, it is right to say that the deficit is partly due to the low charge which is made for telegrams. The fixing of this charge is almost entirely political, and largely the result of an endeavour by the respective parties to catch votes-as it was believed that sixpenny telegrams would be popular-at other people's expense.

If these instances of 'generous treatment' were frequent in Great Britain, it is not unreasonable to suppose, as I have speculated may yet happen in the United States, that there would soon be no anti-municipal trading party left, for traders would look to the municipal estate as the common dumping-ground for their property and effects, assured in the belief that in the local authorities they had a good customer for their businesses, whether the latter were prosperous, drifting, or insolvent. And, as a matter of fact, it is undertakings which sometimes sail pretty close to the two last-named definitions which more often than not come 
into the municipalities' hands. The circumstance that these undertakings in the United States do not have short franchises as in England, and hence are not obliged to sell to the local authorities, will make the acquisition of them even more expensive than has been the case in Great Britain. One can imagine the ardour with which owners of depreciated land and houses in London would seize upon the decision of the London County Council to buy up what is but an incubus. Such is the demand which that municipal whole-hogger, Mr George Bernard Shaw, put forward in the London Tribune. 'Give the Council power', says he, 'to acquire London land, and build or rebuild the whole Metropolis, slums and squares, mews and avenues, courts and King's ways alike.' 'Yes, give the Council that power', echo these property owners. 'Let others bear our burdens.' As Mr Shaw confesses that British municipalities 'are restricted to the building jobs which private enterprise rejects as not worth while' (an overwhelming confession, by the way, of municipal failure to solve the housing problem), the extent to which the Council would be loading their already hampered estate by such a purchase of property beggars description.

It is more common, however, for municipalities to purchase, for a mere song, properties which they themselves have deliberately helped to cheapen. To instance briefly electricity works and tramways (each of which demands a separate chapter later on), their development is retarded by the eventual municipal expropriation at their bare value, after a certain number 


\section{THE DANGERS OF MUNICIPAL TRADING}

of years - a fate which hangs over their heads. Private promoters, therefore, are not encouraged to improve their plant or services, knowing that any money so spent would be wasted, for at the close of their franchise the municipality steps in, takes the concern over as so much scrap, and the struggles of the company are at an end. Meantime, the municipality declaims loudly about the inefficiency of the private working of the system in question (for which, as I have said, they themselves are virtually responsible) as a justification for their intervention. It is not difficult to accuse a crippled man of being inefficient in the sense that he cannot accomplish the same physical labour as if he were not maimed; but who has less right to reproach him with his weakness, and to hold him up to public contumely, than the man who has maimed him ?

Taxpayers of the United States have had the vaunted success of British municipal undertakings dinned into their ears ad nauseam. No less advertised has been the defence of the municipalities that they have done what they have through moral compulsion-namely, through this alleged 'inefficiency' of private enterprise. Where private promoters have any sort of freedom in a land where the 'liberty of the subject' is supposed to be sacred, the charge, it hardly needs saying, will not hold water. But it is a land also where the 'liberty of the company', unlike that of the individual, is not so respected, for a body of traders which happens to run foul of a municipality has its growth stopped and its opportunities curtailed. Like a pirate 
ship, a municipality bears down on private craft, but fearing to risk capture in open warfare, first makes its victim unseaworthy, to be captured at will. Then it rebuilds and re-equips the prize with lavish expenditure of public money, and sends it forth on new voyages under the municipal flag. Small wonder, then, that an undertaking under municipal auspices achieves some measure of 'success' - just the measure, in fact, which it would have done in private hands, had it been permitted. But it achieves no more than that. Or in order to obtain a successful undertaking on expropriation, which would obviate the necessity of re-equipment, a municipality may lie low, and allow private enterprise, during the franchise of twenty-one years, to develop a tramway scheme to the utmost, so that, when it gets into the hands of the municipality at half its capitalized value, it is in a high state of efficiency and organization. ${ }^{1}$ In this case a local authority becomes possessed of a ready-made success which it is not difficult for them to continue; and they can claim no credit (though they do so) for keeping the undertaking up to the mark achieved by the private company, who, after performing all the spade-work and bearing the heat and burden of the day, have tamely to surrender their property as soon as it promises to yield to them some reward for their labours.

Another aspect of the crippling policy of the municipalities has been effectively illustrated by Mr Dixon $\mathrm{H}$.

${ }^{1} \mathrm{Mr}$ W. M. Murphy. Before Municipal Trading Committee, 1900. 
Davies. ' 'There are certain industries which involve an amount of interference with public rights. These, it is suggested, cannot be properly kept under control, and, therefore, the only alternative to disorder is to have them municipally administered. The truth is that the authorities are so infected with the idea of acquiring them that they do not honestly try to regulate them. Their policy produces a reactive tendency in the same direction on the part of the companies. A gas company or a tramway company see expropriation looming through the fog of local controversy. Its directors do not see why the authorities should choose their own time for the purchase, and, therefore, they themselves aggravate the situation in order to hasten the decision of the authority to buy out the company at the precise moment when it will suit them-in view of the depreciated state of its undertaking and of the capital difficulties ahead-to part with the concern. If the policy of acquisition were definitely abandoned, the authorities would be able to enforce a much more effective system of control.'

Lax municipal regulation, in order to hasten the end of a private undertaking, does not favour the proposition that, once in municipal hands, it is likely to perform superior public service ; on that score, indeed, the municipalities have no case worth the name. But the municipal boast of superior public service has been enlarged by ownership pamphleteers as a persuasive to win over American taxpayers to the acceptance of the

1 Before the Society of Arts. 
principle that ownership, on this and other grounds, should be generally adopted in the United States. If American cities are going to permit themselves to be enslaved by the idea, and to follow blindly in the footsteps of Great Britain, will they reflect upon the cost ? It is no light venture. The troubles which overcame them after the close of the Civil War, through the adoption of a similar policy, will be nothing to the straits in which they will be landed if they repeat that experiment to-day.

Let it be assumed that they acquire public undertakings, in addition to those they already possess, in the proportion which British municipalities have done. We may dismiss waterworks, as it is generally conceded that water is as much public property as the rainfall, and should be conserved and distributed by the public authority. It will suffice if we confine our programme of prospective municipal activities to an extended ownership of street railways, gas-works, electricity works, and telephones, though the survey might well be wider.

In Great Britain in I903-04 there were 320 tramway or street railway systems of a total capital value of $£ 52,675, I 52, I_{4} 6$ of which, representing $£$ I9,7Ir,008. were in private hands, and I74, representing $£ 32,964$, I44, in municipal hands-say, roughly, 60 per cent. of the whole tramway capital. The capital value of all the street railway systems of the United States in I902, according to the special reports of the Census Office issued in that year, was $£ 263,144,592$. If a number of 


\section{THE DANGERS OF MUNICIPAL TRADING}

these were transferred to American cities, with a total capital value proportionate to that of the British municipal systems (6o per cent.) compared with the capital value of the private companies, this would mean that the American local debt would be increased by £I57,868,755.

In Great Britain in the same period there were 720

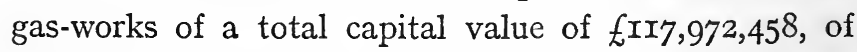
which 459 , representing a capital of $£ 80,869$, I79, were in private hands, and 260 , representing $£ 37,103,279$, were in municipal hands-say, roughly, $3 I^{\frac{1}{2}}$ per cent. of the whole gas-works capital. The total number of gas-works in the United States in I900 was 877, with a capital value of $\mathcal{I I I}_{\mathrm{I}}, 400,000$, according to the Census reports of I902, of which $£ 346,9$ I8 represented municipal works. But in I904 the municipal gas undertakings had a capital value increased to $£ 6,146,382$. If American cities increased their holding in gas undertakings in the British ratio to the whole, after allowing for the proportion they owned in I904, the American local debt would be further expanded by $£ 32,530,000$.

In Great Britain, according to the latest statistics, there were 778 electric supply 'orders', or concessions, in operation-namely, 297 to companies, and $48 \mathrm{I}$ to local authorities. The capital value invested in these undertakings is $£ 67,000,000$, of which $£ 32,000$, 000 represents private capital, and $£ 35,000,000$ municipalsay, roughly, 50 per cent. of the whole. The cost of construction and equipment of the electricity works in the United States in I902, according to the Census 
returns of I903, was $£$ I00,948,070. If a number of these works were also transferred to American cities with a capital value proportionate to that which British municipal works bears to the whole capital (50 per cent.), after allowing for the value of the electricity works they possessed in $I_{904}(£ \mathrm{I}, 576,497)$, there would be a further $£ 49,685,786$ to swell the American local debt.

In Great Britain in 1905 there was $£ 16,765,530$ invested in telephones, of which $£$ II, 265,858 represented the capital of private systems, and $£ 5,499,672$ government and municipal systems, the latter sum being, say, $33 \frac{1}{3}$ per cent. of the entire telephone capital. The total capital value of the private telephone systems in the United States on latest figures amounts to $£ 76,906,8 \mathrm{I} 3$. If a portion of these systems were taken over by the State legislatures or by municipalities in the same ratio (33 $\frac{1}{3}$ per cent.) as the government and municipal-owned systems in Great Britain bear to the private systems, there would be an addition of $£ 25,635,604$ to be made to the United States local debt.

These additions would stand thus :

Municipalized United States street railways $£$ I 57,868,755 (in the same proportion as in Great Britain)

Municipalized gas-works.............

(in the same proportion as in Great Britain)

$32,530,000$

Municipalized electricity works

(in the same proportion as in Great Britain)

Municipalized telephones

(in the same proportion as in Great Britain)

$49,685,786$

$25,635,604$

Total increased local indebtedness

$£ 265,720,145$

Add existing local indebtedness in $1904 \ldots . .3 \quad 304,292,53 \mathrm{I}$

$£ 570,012,676$ 


\section{THE DANGERS OF MUNICIPAL TRADING}

The rate of interest the cities would have to pay in order to raise this sum of $£ 265,720$, I45 would not be less than 4 per cent. (which New York is paying now), so that it may be calculated what a pretty bill the taxpayers would have to pay annually in interest alone if the example of the mother country is going to be followed to these lengths. What body of public men, with any knowledge of the economic principles upon which States and cities are firmly founded, can view such an accession of civic liabilities and responsibilities without alarm, and would leave no stone unturned to prevent the overwhelming accumulation of municipal interests which it indicates? The present activity of the ownership party in the United States warrants the fear that the movement may yet extend to these proportions; but surely no sane public body would suffer itself for long to be dragged by the heels of the Socialistic dreamers and opportunists if by so doing it becomes a party to bringing financial chaos and ruin upon the community. Yet this is what Mr. Bryan in a speech in Madison Square Garden proposed to do. Nay, more, for he included the trunk railways for the National Government and the railways within the States of the Union for the various State Governments to own and operate. That even Mr. Bryan should afterwards have withdrawn this plank from his platform, having thought better of it, shows that the argument, especially as applied to the United States, becomes a reductio ad absurdum.

The United States is too large a country for the municipalities successfully to foreclose on public works in 
this way, and hold them as common properties. An illustration of the ownership theory pushed to its maximum lengths may be obtained by looking at two particularly large countries-Russia and Australia(each of which will be considered separately), where, under a different environment and auspices, the ownership illusion has brought about one 'finality' from which all cities might take warning with profit. In Russia, as we shall see, the absorption of industry by the Government and municipality is rapidly building an omnipotent State owner and a sole dispenser of all sources of wealth-a condition in which officialdom increases and multiplies, while those compelled to bear the burden find it more and more difficult to earn their daily bread.

The objections to the English (or American) citizen embarking in commercial business 'on the joint credit of himself and his fellow-ratepayers,' as it has been termed, seem to me to outweigh any of the supposed advantages of Municipal Trading-namely, cheaper capital, better service, higher wages of labour (which means that municipal employes are paid at a higher rate than private employes, who contribute, by indirect taxation, to this higher scale of wages, which they do not themselves enjoy), profits in relief of rates, solicitude for the consumer, deep concern for posterity (a concern considerably tempered by leaving future generations to redeem huge loans), escape from the 'claws' of the companies, superior control of the monopolies, and, lastly, that most fallacious of all claims, 'the 
revival of the municipal spirit,' which, we have been told, has inspired all these enterprises. The true municipal spirit should have nothing to do with either the acquisition or management of industries that do not concern the well-being and happiness of all citizens of the community. It may rightly regulate and control such industries, and zealously guard the granting of rights, privileges, and franchises to private companies. But the fact should always be remembered that a municipality can more effectively keep the 'slum landlord'. in order when it is not a slum landlord itself, and that it is far easier for local legislatures to control and regulate street transport by requiring low fares, quick service, and extension of tracks from private companies, when they are not tainted with the feverish desire for acquisition, rather than when that distressing disease permeates them. Let them do everything possible to brighten and improve the lives of the people-afford them better hygienic conditions by improved sanitation; provide more parks and open spaces, and increased school accommodation; encourage music in the parks ; and promote other movements for uplifting the masses and for maintaining the municipal spirit at the level which makes the work of individual corporate bodies count in the progress of a nation. Above all, let the city fathers teach self-reliance and self-respect to those who enjoy the fruits of their enterprise in these directions by enjoining upon them the duty to contribute their fair portion to the upkeep of such benefits, and not saddle the entire cost on one section of the community. 
In short, municipalities must be imbued with the sense of social justice.

There is field enough and to spare for the fullest display of civic virtue and devotion, and likewise business acumen, within the recognized boundary of municipal work, without going beyond it. If it were true twentyfive years ago that therein they had more than ample scope for their activities, it is tenfold true to-day, when, wholly apart from trading, the ramifications of municipal duties, either imposed on local bodies by Parliament, or automatically developed by modern needs, growth of population, and new ideas, have spread far beyond their former limits.

The irreconcilable adherents to the shibboleth which has become a catchword in local politics-' No finality in Municipal Trading'-however, turn from such a programme as offering too small game for them to pursue. By statutory power they propose to make every municipality in the land a competitive manufacturer, offering higher wages and less hours to the labourers able to secure municipal employment. This is the bait offered by candidates to the trade unions-let us hope not to secure election-and to the public other attractions, such as cheap transportation and commoditiesor perhaps I should say, to that portion of the public using the particular venture. If, as regards these works, all within the community had an equal interest, as I have before emphasized, or if those who pay the local rates could justly be called upon to defray the portion of those who do not pay rates, there might be less 
ground for the protests of angry taxpayers. This, however, is not the case.

The result is that the municipal arena is now divided into two camps-those (the lesser portion) who pay and do not equitably enjoy what they pay for, and those (the larger portion) who enjoy that for which they do not equitably pay. Hence, the self-development of municipal bodies into unlimited liability trading corporations (the outcome of which is to curry favour with the many at the expense of the few) has created a conflict of social forces in Great Britain, the end of which is not yet in sight. Around the sacred person of the town clerk has grown in many English cities a power which has developed into a competitive business force, oftentimes antagonistic to the largest ratepayers-a force that unjustly compels the ratepayer to assume responsibility for loans to promote industrial undertakings which, if successful, will not only compete with, but ultimately destroy, his own business. In fact, ennobling civic work in which all could join has become blemished by the intrusion of the sordid ambition to utilize public credits in moneymaking. It is a sort of 'heads-I-win-tails-you-lose' proposition for the wirepullers who initiate and develop the policy. If the industrial venture proves successful, the profits are used to meet the deficits of some less fortunate ventures; and if unsuccessful, the ratepayers pay the bill, and there is an end of it. The 'joint credit of himself and his fellow-ratepayer' is an attenuated fiction, as 'himself' generally proves to be 
either the member anxious to retain his seat or the town clerk seeking a larger field for his activities, and, consequently, increased prestige and, perhaps, emoluments. The 'credit' is furnished by the ratepayer, who is rarely even consulted, for to an increasing extent pecuniary responsibility in English cities is becoming divorced from control. Taxation and representation do not go together. Those who provide the bulk of the funds for the authority are without any voice at all in the election of the local governors or in the control of their policy. Matters of police, health, and education concern all the ratepayers equally. Industrial and trading undertakings are not of equal concern, and the control of them can only justly be vested in those who provide the funds for carrying them on. In short, the primary duty of a local government council is to govern, and not to trade, and to this proposition there should be no exception whatever.

On these broad grounds, then, the case against Municipal Trading is undoubtedly a strong one-sufficiently strong, I should think, to prevent those who advocate its debatable advantages from making further headway in a country like the United States. In Great Britain and in some of its colonies the problem presents itself in a somewhat different form, and the question is, Shall this policy, which has already been adopted, be continued ? Shall it be fostered by the sanction of the people, or uprooted as a failure? Its propagandists claim for it many virtues, the foundation of which is public beneficence-always, it is well to remember, with 
public money. The fundamental virtue which its supporters pride themselves on is their ability to speculate with other people's money-a quality which, one would think, demands a higher standard of intelligence, courage, judgment, and virtue than to speculate with one's own money. As a matter of fact, most of the commercial advantages of Municipal Trading have during the last few years been exploded. Sound commercial firms in England pay no more for their capital. It has been demonstrated over and over again that a municipality can do the work no cheaper than, nor, indeed, so cheap as, private concerns. No one familiar with the facts will contend that a town council, constantly changing its membership, is a better board of management than the board of directors of a successful company. There is no proof that the consumer is specially benefited; the service, uncer private ownership, is equally good-in most cases it is far better-and the relative cost, after considering differences in price of labour and of raw material, is less.

The duty of private traders, if they are to succeed in calling a halt to the advance of the municipalities in both countries, is clear. They must once and for all nail to the counter the lie that they extort unfair profits out of the public, and also fail to perform good service. Such is the municipal trump-card, and private traders must see to it that by playing it the ownership party fail to score. The keynote of the policy of private traders must be well-doing, and it has been well sounded by the President of the American Gas-Lighting Associa- 
tion. In his annual address four years ago he said: 'We believe that the governing authorities of municipalities must be brought to a realizing sense of the importance of conserving vested rights, and the surest way to coin public favour is to deserve it. The identity of interest idea must prevail with the public. Privately owned companies, where ability and enterprise are rewarded by added compensation to managers and just profits to owners, and where the merit system is found at its best, will doubtless hold their own for a long time to come against any demand for public ownership; but the best safeguard which we have against the seeming trend of public opinion is our conduct toward the communities we serve, which should result from the careful study of the interests of the public from the attitude of good citizenship.' 


\section{CHAPTER III}

THE DESTRUCTION OF INDIVIDUALITY-RUSSIA AS AN OBJECT LESSON

FTER all, civilization is but a man incessantly
advancing. The progress of the world in politics, in arts, in invention, in manufacture, in ideas, and in all that goes to make up our complicated existence, centres around individual man. Who have taken the steps forward? Not Governments, nor States, nor municipalities, nor ' committees of citizens', nor ' town meetings', but individual men, inspired with new ideas and earnestly intent on carrying them into effect. It is individual men who have harnessed rivers and waterfalls for our manufacturing, who have drawn unseen elements from the atmosphere for transport and to carry our messages across the ocean, who have improved navigation, invented all useful methods, sought out and found the innumerable properties of matter, and who, in fact, have been, from the beginning of the world to the present time, the source of all advancement. The distinction and end of a soundly constituted individual man is his labour, and of that no State has a right to rob him. Glancing over the nations of the world as 
at present constituted, we find that where the individual man has been allowed the widest latitude and freest play for his genius and energy, there has been the greatest progress. On the other hand, in countries where the ruling policy has been to make all men alike, to extinguish individuality, and to choke all channels of invention and inspiration by Government interference, where man no longer conducts his own life, there we find stagnation and impoverishment. In short, the endeavour to manufacture a man's life for him, by the very nature of things, always has been and always will be a deadly failure, no matter by whom promoted and by what power enforced.

The tyranny of the tyrant is no worse than the tyranny of the democrat. There is no essential difference in the policy of universal expropriation initiated in Russia by Count Witte, and continued by the ministers who have followed him, and that of British local bodies under the guise of Municipal Socialism-a policy which, as State Ownership in Australia, has practically driven individual enterprise from that continent, as we shall see. In Russia millions have been spent in building up a vast fabric of State and Municipal Ownership, and naturally patronage is becoming the strongest pillar of irresponsible rule. The State in Russia has been truthfully characterized as a trading corporation first, and an organ of government only as a subordinate function. This is precisely what Municipal Trading is rapidly making of English cities and towns, and State Ownership bringing about in Australia. In the latter country 
the government is in the hands of those whose interests as workers lie in extravagant outlays on public works, whose knowledge of finance is limited, and who have little to fear in the event of collapse-inshort, the government may be described as expressing the collective wisdom of ignorance. In Russia the power moulding these schemes is vested in the Finance Minister, who is gradually absorbing all industries and reducing the producing population to the position of managers of State departments, civil servants, and State labourers. The pretext for these operations in Russia is identical with that urged by the English Socialists and Australian Labour party, namely, public beneficence, or the protection of the individual against the individual. The result in Russia, as in England and Australia, is the blight of individual effort and the poverty of the private traders, who pay the taxes. In Great Britain and its colonies the power moulding these schemes is vested in those who expect to benefit by increased wages, shorter hours, and additional patronage. In Russia the power shaping these schemes is vested in a single minister, whose aim is to buttress in every possible way the power of the State, and who is bent on centralizing the whole wealth of the country in a single hand. In the one case, it emanates from the top down; in the other case, from the bottom up. But wherein is the difference? The results are precisely the same.

That this parallel is not an exaggeration may be easily proved by a closer examination of the aims and 
ambitions of the British Municipal Socialists on the one side, and those of the so-called 'maker of modern Russia', Count Witte-who is responsible for the modern development of the Russian bureaucracy-on the other. We are familiar with the industries for which powers are constantly being applied by British municipal authorities. They include the manufacture of engines, dynamos, gas and electric fittings, paving materials, bricks, cold-air storage, and ice-supply, milksupply, besides the control of concert-rooms, hotels, Turkish baths, and cycle-tracks. Tram-car factories have been established, and even a brass foundry to make fittings. Municipal telephony has been undertaken, and, after an inglorious existence, is now moribund. Municipal fire insurance has been established, and a universal system has been proposed. Municipal banks (a system of receiving deposits in many towns is now in vogue which does not greatly differ from actual banking), the issue of municipal banknotes, municipal pawnbroking, municipal bakeries, municipal collieries, municipal public-houses, municipal printers, and municipal tailors, have all been seriously suggested.

If these extraordinary proposals represent Fabianism, there is only one place I know of in which they may be found in full force, and that is in the Russian Empire. The carrying out of such a policy in countries like Great Britain or the United States would be nothing short of national and industrial destruction. Individual endeavour is to be forcibly robbed of the fruits of its labours, and the State and municipality is to take charge 
of the exploitation of all common needs and ascertained processes. Having been thus deprived of that which is rightly its own, private enterprise is to be hidden to invent new processes, initiate new methods, create fresh wants and found new industries, so that, in due course of time, State or local government, with their enlarged powers, may seize or appropriate them. Here we have a plan of universal expropriation mapped out which would do credit to Count Witte. Like the British municipal trader, that statesman has invented a system by which the State or municipality, as the case may be, marches to wealth; the people or ratepayers, as the case may be, to ruin; and the minister or town clerk, as the case may be, to omnipotence or assassination. Russian policy is precisely that of the advocate of Municipal Socialism-namely, the creation of an omnipotent State owner or sole disposer of all sources of wealth-that is, a State, as one writer describes Russia, with the civil inhabitants merged in officialdom, dependent upon the Government for their daily bread, and servants of an autocracy for ever.

The above programme Mr Bernard Shaw must have had in mind when he wrote in Fabianism and the Empire (a manifesto intended to convert the electorate to Socialism at the General Election of I900): 'If any candidate at the election shows the slightest weakness on this subject (Municipal Trading) he should be voted against without regard to party. And the opportunity should be seized by the next Government to enlarge the powers of local bodies until they are able to force private enterprise into 
its proper sphere, which is not the exploitation of common needs and ascertained processes, but the sphere of invention, initiation, and the creation of new needs and new industries.' Russia must surely be the municipal trader's paradise, and St Petersburg and Moscow, not Glasgow and Spring Gardens, his ideals. No more subtle means of concentrating the wealth of the people and exterminating private industry and initiative could be hit upon than the policy established in Russia, which is all the more destructive in being practised-as it is in Great Britain-to mislead taxpayers into the belief that it is philanthropic and progressive in spirit. This motive, ingeniously strengthened by actions that bear upon the surface a specious goodwill and sincerity, even wins the sympathies of those who mistrust the Witte policy and its continuance by his successors. Before Chicago citizens became exercised about who should run their street railways, and before London ratepayers were exasperated with their County Council for its blind attempts to establish an elaborate ferry service on the Thames with little traffic to support it, in Russia everything had become municipalized. The State deserves some credit (such as it is) for being content with working the railways, mines and steel works, and selling vodka ; but the local governments place no such limits on their enterprise. They sell agricultural machinery, seed, horses, cattle, sewingmachines, text-books, medicines, and magic lanterns, to say nothing of managing theatres, delivering lectures, translating foreign classical writers, and bowdlerizing 
the works of authors of their own country, for the benefit of the masses. One city (Tiflis) even competes with its retail butchers, and also sells sewing-machines on the instalment system to impecunious seamstresses. ${ }^{1}$

The attempts of Russia, since the war with Japan, to raise foreign loans reflects the internal financial condition of the country. Other countries, whether through war or other causes, that seek money to put their fiscal machinery in order, obtain all they require from within their own borders. Russia has to seek the assistance of capitalists of other nations. It is the universal system of State and municipal expropriation of property honeycombing the whole country which accounts for the inability of her own people to supply her with funds. Only by ruthless taxation can it be supported. Its autocracy wants much of itself, and the vast trading bureaucracy no less. Between the two the people are well drained. The false complexion of public benevolence under which the blighting process is pursued is soon rubbed off by the discovery that it only means a yet more bloated officialdom and a leaner peasantry. So that, looking below the surface, not everyone is deceived. The tribulations of Tzardom daily recorded by the newspapers, the subterranean workings of the revolutionary party which periodically reach the surface in death-dealing explosions of revolt, and the spiritual influence wielded by Gorky and Tolstoy, to stem which the temporal powers of the State are helpless, reveal too clearly that the mute millions of Russia are raising their

1 Mr R. E. C. Long, Fortnightly Review, I903. 
voice in their own way against the Socialistic creed which will have it that no man's soul, body, purse or possessions are his own, but belong to the community-that is, to a horde of man-eating beaureaucratic officials and their countless minions and parasites.

As onlookers see most of the game, it is outside Russia that the true prophet is most likely to arise. At the close of the war, one arose in Berlin-a statistician of note and a Councillor of State-by name Rudolf Martin, who wrote a brochure called Die Zukunft Russlands und Japans ('The Future of Russia and Japan '), wherein he boldly said that the bankruptcy of Russia is one of the certainties of the near future. This is a form of courage which Germany, like her neighbour, did not appreciate, and $\mathrm{Mr}$ Martin was denounced by his Government. In England Mr Martin's views were regarded at the time as reflecting in some respects the power of observation and originality of conception which marked Bismarck in his early years; but, unlike Bismarck, he got more kicks than halfpence for his pains. Despite his Government's taboo, however, his views were greeted as showing that there are some men even in the Fatherland who understand tha tendency of world forces, and have the courage not to be silent. Russia's bankruptcy, he thinks, may be delayed for ten or fifteen years, but it probably will come sooner than later. Advancing reasons for his views, he points to the condition of Russian agriculture, which at present, he states, produces per head of those engaged in it one-eleventh to one-tenth of the corresponding figure in the United States; whilst the same rich, black 


\section{THE DANGERS OF MUNICIPAL TRADING}

soil of Muscovy, acre for acre, produces only one-third of that from the inferior soil of Germany, and a fourth to one-fifth of that of England and France. Decades of industrial education and hundreds of millions of roubles, he calculates, are necessary to ameliorate the condition of things in any substantial degree. But there is no indication that the Slav race has the needful impulse to make the effort. How can they, when, from the top of Russian society downwards, they are officialized out of all individual enterprise? No one, themselves least of all, would benefit by any accession of their energies, except their pastors and masters, that is, their local authority-in its turn the limb of the bureaucracywhich enters remorselessly into their personal lives by laying a heavy hand upon the yield of their labours, saying, "This much shalt thou have, and this much the State', and the State's portion is the greater. To be sure, Municipal Socialism must be kept up by some means. It is the lack of stimulus in the Russian peasant to cultivate his land (which must plainly be attributable to a want of self-respect and of real patriotism, however much he may show a sentimental adoration of the reigning dynasty) wherein lies the hopelessness of Russian agriculture. $\mathrm{He}$ would only be working for the support of a vast trading bureaucracy, which wants all he can give for its corrupt officials to batten upon. Those who think, with such a widespread wet blanket, chilling all personal initiative in Russia, that a new paper Constitution, or a Duma, will do anything to effect the regeneration of that country are blindly 
ignoring the lessons of history. Russia, in her present plight, affords a shining example of what may befall a country which pursues State and Municipal Trading on extensive and uncompromising lines. The war, and the Russian idea of government, are contributory causes; but it is excessive taxation, for whatever purpose, which constitutes the main one. Russia in I905 had the second largest debt of any country in the world-namely, $£ 825,000,000$, of which she owed over $£ 500,000,000$ to foreign countries, which makes her the greatest international debtor of all times, in contradistinction to other nations, who borrow of their own people. Her foreign debt also is bound to grow. The average favourable balance of her foreign trade during the past ten years has been $£$ I9,000,000 a year, while for interest, etc., she has to pay $£ 37,000,000$ a year. By the issue of fresh loans, so far, the difference between these two amounts has been met; but the annual deficit in the balance of trade will expand with the growth of the foreign debt until it reaches $£ 30,000,000$ per annum. That stage reached, on the calculation of Mr Martin, Russia will be unable to make any fresh loans-which means bankruptcy.

The Paris Temps has stated that the present deficit has already reached the sum of $155,000,000$ roubles (about $£^{\mathrm{r} 6,390,000)}$, and if this be true, and Mr Martin is right, then Russia is even now more than half way insolvent. In contradiction of his report come some ' official figures' published at St Petersburg, which put the present deficit at $60,000,000$ roubles (say $£ 6,344,000$ ); 
but, whilst making every allowance for their source, there is more reason to believe that the real deficit more nearly approaches the larger figure.

Hitherto Russia has accomplished much by resorting to the common device of State and municipal managements-making a shop-window show of her financial status. But the impressive gold reserve she has flaunted before the eyes of the world is all borrowed money; still, that treasured hoard has formed the unlimited letter of credit by which she has drawn on the leading countries. With its due disappearance will depart Russia's power to raise further money. Mr Martin counts it the patriotic duty of everyone familiar with the facts to utter a warning against the engulfing of further millions in the abyss of mismanaged Muscovy.

To much of this discredit has a baneful system of State and Municipal Trading brought a great country. Under the system devised by Count Witte the local governments are said to act as 'the Financial Minister's jackals', eliminating the private trader and creating vast organizations which the State, in the course of its continuous warfare against free local government, expropriates. The policy is to shackle everyone's initiative but that of the Finance Minister. As the local governments are completely under his thumb, their enterprise is merely State trading in another form, which has the cardinal advantage that it hampers individual enterprise and passes thousands of free individuals under the yoke of administrative tutelage. And the 


\section{THE DESTRUCTION OF INDIVIDUALITY 55}

solemn pretext for this destruction of private enterprise is identically the same as Mr Shaw's 'public beneficence' nostrum. Indeed, the Russian policy should warm the heart of the strenuous municipal trader-British or American-for it is destined to end in the absorption of all industries, and in the reduction of the producing population to the enslaved condition of State and municipal officials of various grades. 


\section{CHAPTER IV}

THE PUBLIC WORKS POLICY OF AUSTRALASIA

THE present condition of Russia, with its dynasty

1 and bureaucracy alike in danger of being wrecked sooner or later by the revolutionary party, hardly warrants our looking to that country for the realization of such a state of things. She has gone so far, but she cannot go much further. Revolution bars the way. We must turn to another country (Australia), where no such overwhelming obstacle is present. There State and municipal aggrandizement is proceeding at an equally rapid pace, and is likely to reach a stage in course of time which promises the fulfilment of the worst predictions of economists.

Already, we are told, the State servants constitute almost a clear majority of the names on the electors' rolls; the State, indeed, is on the way to becoming the sole employer of labour in the community. And who are they, it is asked, who work this juggernaut, who run this overgrown business of State? They are, we are informed, 'often men who, in private life, hardly show fitness for administrative duties.' It is therefore not to be wondered at that political efficiency is not 
what it should be, that politicians as a class compare unfavourably with those of most European countries, that corruption is said to be increasing, and that the average member of the Australian Parliament is tempted to be concerned only about arranging the appropriation of public money for railways, waterworks, and other undertakings to furnish his own constituency with profitable employment.

The public works policy of Australia began with the partial ownership of land and a complete grip of landtransport. If it had stopped at that all would probably be well, as Government land is not unknown in other countries, and railways have become partially Stateowned in a republican country like France, in a bureaucratic country like Germany, and in a British Dependency like India. But Australian Socialism having driven in a preliminary wedge by the capture of the lines, has since then gone far. Here, for instance, are some of the undertakings which chiefly account for the public debt of South Australia : Railways, tramways, post-office, telegraphs, waterworks, sewers, jetties and lighthouses, land repurchase and homestead blocks, and harbours. These works are representative of the public works policy of the other States. One would think that the Socialistic programme having been thus far carried out, the time had come for a prudent pause in order to see the economic outcome of experiments never before attempted, and to determine the expediency of their continuance or otherwise. But the aim of the Labour Party of the Commonwealth does not 


\section{THE DANGERS OF MUNICIPAL TRADING}

contemplate marking time, unless an anti-socialistic reaction-by no means unlikely-compels it to do so. To-day, according to trustworthy authority, its demands for the suppression of individuality are loud and uncompromising. The Queensland Labour Party has a programme the principal object of which is the 'collective ownership of the means of production, distribution, and exchange, to be obtained through the extension of the industrial and economic functions of the State and local governing bodies '; whilst, in addition to State railways and waterworks, they desire 'State fire and life insurance, State breweries, distilleries, and taverns, and the importation, manufacture, and distribution of intoxicants to be entirely undertaken by a Government department.' The Victorian Labour Party apparently is less aggressive, as it is certainly less definite in its programme, which expresses the party's object as 'the gradual nationalization by the means of production, distribution, and exchange.' Labour in New South Wales would have 'the securing to all producers of the full results of their industry, by the collective ownership of monopolies, and the extension of the industrial and economic functions of the State and municipality.'

In the framing of the two latter programmes there are symptoms of no little cogitation and verbal jugglery. The intention appears to be to spread the Socialistic net as wide as possible, so as to propitiate all shades of collectivist opinion-from the extreme irreconcilables to the moderates. Unwilling to alienate a numerous class 
(men of limited means) who might be won over to ' a policy of "divide" if their present share of the world's goods did not amount to more than they could count upon in the event of a Socialistic equalization,' ${ }^{\prime \prime}$ some sections of the Australian Labour Party seem to have determined on a line of least resistance in order to counteract the natural impression that their drastic aims mean the destruction of financial and commercial confidence in their country. The nationalization of all industries, however, remains their main plank. But it is not advanced in its entirety; as yet it is far too big a pill for the general electorate to assimilate. The last federal elections were fought on the single issue of whether Socialism was or was not to be the paramount factor in Australian politics, necessitating some agreement between the labour parties of the various States as to what they wanted. A common denomination was apparently arrived at by planing down the main plank to the nationalization only of those industries which were of the nature of semi-monopolies. This clearly is no unattractive bait to the men of limited means and other waverers, if they could be buoyed up with the assurance that, far from their interests being in jeopardy by the change, they would be strengthened. The outcome of this modification of socialistic ambitions was that the electorate were asked to approve-which they did not-of an amendment of the Constitution enabling the Federal Government to acquire and carry on all industries of the nature of

1 Sunday Times, October 22, 1905. 
monopolies. From what has already been said, it is not surprising to learn that 'this limitation is merely a pretence, and that all prosperous industries are aimed at, regardless of their character, as may be seen in the selection of the industries which are avowedly to be dealt with first. In the front rank are placed the sugar and tobacco industries and the Australian shipping trade, while in the second come banking and assurance. None of these, of course, has a monopoly character such as necessarily appertains to railways, tramways, gasworks, and waterworks, which rest upon special legislation. Even, therefore, if the circumstance had not been made quite clear by the teaching of the Watsonites (the Labour Party) in their press and in their addresses, the character of the industries immediately threatened indicates that not monopolies, but all prosperous industries, are the plums which the Socialists consider ripe for their gathering.'

The hope of Australia lies in its Anti-Socialistic Party, whose platform includes 'opposition to unjustifiable Government interference with private enterprise; resistance to the nationalization of industries and enterprises; and opposition to the acquisition by the Government of any industrial monopoly, on the ground that a private monopoly may be broken up by competition, but that, on the other hand, a government monopoly may be supported by legislation.' The leader of the Anti-Socialist Party, Mr G. H. Reid,

1 'A Fair Fight with Socialism,' Daily Mail, May 2 I 1906. 


\section{PUBLIC WORKS POLICY OF AUSTRALASIA 6r}

appears to be reconciled to the present State ownership of general undertakings like the railways and postal services, but he draws his own line of demarcation between them and other schemes. The control of the general services already in the hands of the Australian State, he has submitted, enable the Government to widen the paths of private enterprise (the conclusion is arguable); whilst the Socialists, by bringing in schemes other than general services, seek to destroy private enterprise. But there is no doubt he is right when he says that those "who would suffer most by the mistakes of Socialism would be the working classes, who had no margin to make mistakes upon, and who required every penny they received for the ordinary necessities of life.' ${ }^{1}$

It is apparent, therefore, that the Australian working man, for the most part, is living in a fool's paradise. If the State or city takes away one after another the opportunities for profitable employment of private capital and brains, the logical result is that other occupations become overcrowded, the struggle for existence gets harder, and an increasing number of persons must come upon the State or city for support. It is to be gathered that in New Zealand every second person over sixty-five years of age has a State pension; in Victoria (population I,2I0,305) about every third person above that age is fed by the State. In I904-I905 this State paid away in pensions the sum of $£ 327,634$. In New South Wales (population I,46I,543), 22,000 persons are

1 The Australasian, May 26, 1906. 
pensioned at an annual cost of $£ 508$,000, the distribution of which costs another $£ 20,000$. The latest proposal recommended by a Commission (which urged immediate action) is that a pension of ros. per week, applicable to all the Australian States, should be paid to all reputable persons over sixty-five, to be granted as a right, not as a charity. This is estimated to cost the country no less than $£ I, 500,000$ a year. On the surface this looks like a happy state of things in store for the Australian working man. But what of the classes above him, from whom taxation is wrung in order that public works on a large scale should be carried on, mainly for the purpose of affording employment for a privileged class? What of the working man with a mind of his own, who scorns to affiliate and merge his career in an order of things which, whatever else it might do, acts as a blight on individuality and character, and may ultimately breed a community of drones, sybarites, idlers, and sycophants who will cluster round the ship of State like barnacles? Well, he is kept poor all his life by the increment of taxation levied on him to support his less courageous fellow-creatures; he is, in short, prevented from ' accumulating sufficient by thrift' by the overwhelming impediment of the State, which denies him the right to do so. On this ground the institution of universal pensions is only giving to a man in his old age what circumstances have prevented him from obtaining for himself in his earlier years. But it hardly needs saying that the average man, when past his climacteric, would prefer to live on his own means 
rather than submit to the ignominy of having to come on the State as a pauper. No other fate, however, appears to be in store for him. Pensions, whilst inevitable and just in such circumstances, are merely the completion of a vicious circle.

At present, according to the Federal Budget, and the returns of the various States, Australia is enjoying a period of prosperity that has not been her fortune for some years past. If, despite the presence of Socialistic elements which clog her progress as a nation, she still can show commercial activity, what, it may be asked, would her development be were she able to throw off her fetters and give the fertility of her soil and the enterprise of her people the fullest stimulus and freedom ? The diplomatic optimism of the federal treasurer when revealing the good things contained in his Budget was to be expected, but to attribute the existence of an agreeable surplus as pointing to the success of the public works policy is to credit an artificial condition of things with what is really due to natural causes. There has been no drought. Australian trade is booming in spite of, not because of, Socialistic government. Her history tells us only too well that too much cannot be made of her present trade activity; the next two or three years may witness as big a falling off, with consequent large deficits in the various States, as has been her experience in the past. It is not possible to expect anything more than a spasmodic and short-lived prosperity in any State which is overloaded with debt, on account of extravagant public works, and keeps on adding to 
its heavy involvements. Nor will the vaunted 'surpluses' in the State accounts which point to this prosperity bear scrutiny, as will presently be shown. Here is a comparison of the national debts in I904-I905 of the United States and the United Kingdom with the public debt of the Commonwealth and that of New Zealand, and the two last together:

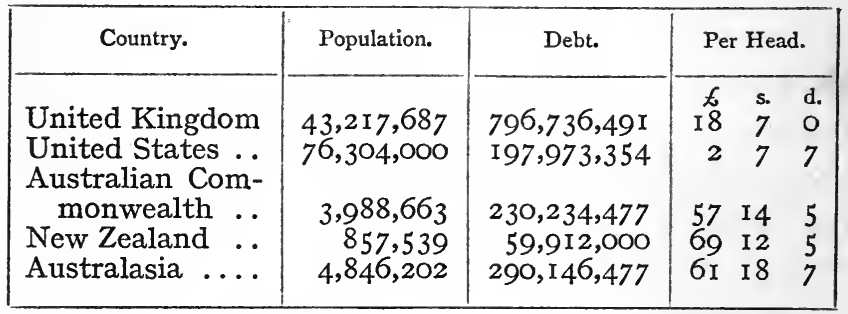

In I870 the public debt of Australasia was only $£ 30,000,000$; by I902 it had jumped to $£ 269,000,000$; in I905 it was as above shown; whilst the Commonwealth's debt only in I906, according to the Federal Treasurer (Sir John Forrest) is, £237,000,000. Taking the figures in the above table, it will be seen that the Commonwealth, with a population an eleventh part of that of the United Kingdom, has a debt per head more than threefold that of the latter country's; with a population nearly a twentieth that of the United States, its debt per head exceeds the net American debt twenty-four times over; whilst New Zealand, with a population a fiftieth of that of the United Kingdom and nearly a ninetieth of that of the United States, has a debt per head which almost quadruples the British debt per 
head, and is twenty-nine times more than the net American debt per head. More remarkable is the comparison between Australasia (the Commonwealth and New Zealand) with four principal American States :

\begin{tabular}{|c|c|c|c|}
\hline State. & Population. & Debt. & Per Head. \\
\hline Australasia... & $4,846,202$ & 290, I 46,477 & $\begin{array}{ccc}t & \text { s. } & \text { d. } \\
6 \mathrm{I} & \mathrm{I} 8 & 7\end{array}$ \\
\hline New York State. & $7,588,259$ & I, 499,647 & 040 \\
\hline Pennsylvania.... & 6,5 10,91 5 & 74,925 & 03 \\
\hline Ohio $\ldots \ldots \ldots$ & $4,254,589$ & 937,003 & 45 \\
\hline Illinois $\quad \ldots \ldots \ldots$ & $5,020,590$ & $43 \mathrm{I}, 024$ & I IO \\
\hline
\end{tabular}

This table presents extraordinary features. We find New York State, with a population which by now must be approaching double that of Australasia, confining the State liability of each of its inhabitants to a trifling sum of $4 s$., whilst the people of Australasia, as a consequence of Socialistic legislation, have each become involved to the tune of $\AA^{6}$ I I8s. $7 d$. Pennsylvania's limitation of its State debt to $3 d$. per head, by the accumulation of sinking fund assets, stands out in still stronger relief in contrast with the Australasian debt; whilst Ohio and Illinois (both of whose populations approximate fairly closely to that of Australasia) manage to go on and prosper with a State debt which compares almost as favourably.

If we take the individual debts of each of the six Australian States, and also of New Zealand, and compare the figures with the indebtedness of certain American States whose populations more or less approximate to theirs, no less striking contrasts appear : 


\begin{tabular}{|c|c|c|c|c|c|}
\hline State. & Population. & Debt. & \multicolumn{3}{|c|}{ Per Capita. } \\
\hline New South Wales. & $\mathrm{I}, 46 \mathrm{I}, 533$ & $82,321,998$ & $\begin{array}{c}t \\
56\end{array}$ & s. & d. \\
\hline Kansas $\quad \ldots \ldots \ldots$ & I, 470,495 & I 26,400 & 0 & I & IO \\
\hline Victoria ....... & $\mathrm{I}, 2 \mathrm{IO}, 3 \mathrm{O} 4$ & 51,5 I9,962 & 42 & I & 0 \\
\hline Maryland $\quad \ldots .$. & I,2I 7, I 74 & 988,479 & 0 & I6 & 3 \\
\hline Queensland ...... & 521,655 & $4 \mathrm{I}, 264,467$ & 79 & 2 & 5 \\
\hline Washington $\quad \ldots$... & 550,277 & I I 4,628 & 0 & 9 & 2 \\
\hline South Australia .. & 372,682 & $28,760,545$ & 77 & 3 & $\mathrm{o}$ \\
\hline Vermont $\ldots . .$. & 345,885 & 72,589 & o & 4 & o \\
\hline Western Australia. & 242,889 & I6,642,773 & 68 & IO & 6 \\
\hline Utah $\quad \ldots \ldots \ldots$ & 289,943 & 90,000 & $\mathrm{O}$ & I3 & 6 \\
\hline Tasmania & I 80,200 & $9,722,732$ & 53 & I 5 & 3 \\
\hline Delaware $\quad \ldots \ldots$ & 187,983 & I 52,418 & 0 & 16 & 2 \\
\hline New Zealand .... & 857,539 & $59,946,400$ & 69 & I 2 & 5 \\
\hline Connecticut $\quad \ldots$ & 940,852 & 335,593 & 0 & 7 & o \\
\hline
\end{tabular}

This table hardly needs comment. The reckless establishment of public works in the Australian States, made permissive by an elastic Constitution, and the constitutional prohibition of a similar policy in the American States, is too conspicuously reflected in the high debt of the former, and the remarkable low debt of the latter.

It will probably be contended that Australia has 'something to show' for her large public indebtedness in the shape of certain valuable assets, which the various American States mentioned do not possess. This is true so far as the Governments of these States are concerned; but it should be borne in mind that there is no dearth of the same public services in American 
States. There they are conducted upon fairly satisfactory lines by private enterprise. The States Governments, while not sharing in any imaginary profits, are certainly not assuming any financial responsibilities for future generations to liquidate. The revenue accruing to the State from the taxation of these private enterprises is considerable, and is constantly increasing as the franchises become more valuable.

New South Wales, first and foremost in the amount of its indebtedness, compels attention. This State, like others, has for years been beset with the problem of the unemployed. By instituting vast public works expressly for their benefit, the State adopted a clumsy expedient in an endeavour to correct a condition of things for which, together with the mother-country, it was itself in part responsible. Continued legislative interference with the development of private enterprise naturally results in restricting openings for the secure and profitable investment of capital and in the contraction of the ordinary channels of employment. As the State prevented private persons from extending their businesses, and from thus affording work for the unemployed, a bounden duty was forced on it of doing itself what it would not have others do. The ordinary channels of work being contracted, extraordinary channels must be opened. So the Public Works Department of New South Wales, between I899 and I902, spent the sum of $£ 7,211,089$, of which five millions sterling went in wages, representing fully a million at least, wasted by bad management, possible only under 
the system of day labour favoured by the State Minister of Works. ${ }^{1}$ This had the effect of tempting men from private firms to become State employés, thus further crippling individual enterprise by depriving it of labour. But many of the undertakings were designedly 'relief works ' for the unemployed, and these revealed another seamy side of the State Socialism of which they are a concrete expression. Mr W. Pember Reeves, whilst an advocate of the system, puts his finger on a fatal defect of it when he refers ${ }^{2}$ to 'the disheartening side of the business of aiding the unemployed', and to the method of ' making the work go round. . . . Some of the men cannot work, and others will not. . . O Others, again, go to work late, work easily, and knock off early.' $\mathrm{He}$ expresses his conviction that paying time wages to inferior men on relief works or public works never has answered, and is never likely to answer. 'If the wages are very low', he remarks, 'the result is cruelty; if they are normal, money is wasted.'

To a large extent, also, it is doubtful whether money is wisely spent on projects not avowedly 'relief works', and undertaken by the Australian States with the object of becoming large and regular employers of manual labour. Such undertakings are entered upon largely to keep men employed; they yield little or no profit ; they create heavy liabilities; and much of the revenue realized is naturally required to meet interest on the loans raised. Mr Pember Reeves quotes a speech made

1 Sydney correspondence of The Globe, February I6, I903.

2 State Experiments in Australia and New Zealand. 
in Igor by Mr O'Sullivan, then Minister of Public Works for New South Wales, in which the latter summed up a year's work of his department. It may be reproduced here to show the complacency with which Australian statesmen regard their exploits with public money :

His department was the largest industrial organization in the southern world, and, indeed, there were very few outside Europe or America to compare with it. Between I9,000 and 20,000 men were employed, and he asked them to judge of its usefulness by the amount of work carried out. During the last eighteen months the department had constructed eleven lines of railway, seventeen lines of tramway, had carried out IO2 works with connection with harbours and rivers, eighty-eight sewage matters, twenty-two country water-supplies, twenty-two schemes of water conservation, had erected sixty public buildings, I03 bridges, had put down twenty-four artesian bores, and forty-seven tanks and dams, carrying out in all 499 important undertakings.

Mr Reeves comments that Mr O'Sullivan might have added that in three years (I898-Igor) the department had spent nearly seven millions and a half of revenue and loan money.

It might also be added that at June 30, I905, fully 75 per cent. of the amount of the public debt $£ 82,321,998)$ had been spent on the construction of railways, tramways, telegraphs, water-supply, and sewage undertakings. ${ }^{1}$ The whole debt is stated to bear a mean rate of interest of 3.57 per cent., and the net return on these services for the year I904-I905 is credited with yielding 3.34 per cent. of the cost of construction, or

1 The Statesman's Year-Book, 1906. 


\section{THE DANGERS OF MUNICIPAL TRADING}

2.49 per cent. of the existing public debt, exclusive of Treasury bills in aid of deficiency of revenue. According to this statement, the public works not only do not yield a sufficient return to meet the interest on the whole public debt, but do not earn enough to pay the interest on the loans raised in respect of them.

It must be admitted that a surplus of 3.34 per cent. after expenditure has been deducted from gross revenue is a fair showing, and could almost meet, or even more than meet, the whole interest incurred on the cost of construction if the State had to pay less than 3.57 per cent. on the latter. But it all depends on how the surplus is arrived at. Turning to the finances of New South Wales for last year (I906), a surplus, 'as the politicians put it', of $£ 896,124$ is announced. The journal named, in an article headed 'Works Funds, Surpluses, and Other Swindles', searchingly examines the items set out as revenue, and ascertains that a number of them are nothing more nor less than the liquidation of State assets, such as sales of land, property, and timber, which should not enter into revenue at all, but be credited to capital or loan account. The surplus is further swollen by debiting to loans or capital account a considerable amount of expenditure really made on revenue account. The proceeds of land sales, misapplied to revenue, is put at about $£ 900,000$ a year, a sum which, were it applied to reduction of the public works debt, would convert the surplus obtained by its inclusion in the revenue account into a big deficit.

1 Sydney Bulletin, August 30, 1906. 
But as, we are told, the amount of borrowed money spent in the financial year of $1905-06$ was $£$ I,282,995, the total debt would not, with that addition to it, be relieved by the credit of the proceeds of land sales; the effect of such a credit would not even be a decrease in the increase of the debt, when the latter is also loaded with debits which should be charged to revenue. Hence a proper observance of accountancy principles fails to be helpful to the State Treasurer anxious to show that the net return on public works constitutes nearly the whole interest incurred on loans raised for construction. The surplus vanishes; the relief of the growing public debt is not sufficient to reduce it. The Sydney Bulletin thus assails Mr Carruthers, the New South Wales Treasurer, for employing such methods :

To the bad tricks he took over from his predecessors he has added some of his own. He knows the virtues of a surplus for advertising purposes; and there are few things easier than to 'manipulate' a surplus. All that has to be done is to convert enough assets into cash and use it as revenue, and on the other side charge enough expenditure to capital account. The most unsound business in Sydney could produce a good profit and loss balance in that way. The trouble in a private concern would be that the practice would have to end in a few years when convertible assets run out, and new capital refused to come in; but with a new country to play with, the deception may last a century. Yet there is an end to even the biggest estate, and there is a limit to tax-bearing capacity of even the richest people.

By the adoption of the same accountancy practices a surplus in the coming year is apparently looked for. 
The journal I have quoted winds up a trenchant criticism by the pronouncement that it will be

A purely comic-opera surplus ; but, unfortunately, it will have this effect-it will make borrowing easier; for the vast crowd, both at home and in Europe, who won't take the trouble to understand the process, will stare openmouthed at an annual surplus. And those at home will be more willing to go in for another loan-drunk on the strength of their 'prosperity', and those abroad will be more ready to accommodate them.

To turn from the State to the municipality in New South Wales, and glance at the manner in which the finances of the suburbs are handled, only strengthens the belief in the unfitness of the greater or less authority to conduct public works. In I904 the expenditure of the city of Sydney was $£ 200,000$ over and above its revenues; its suburbs and the boroughs and districts beyond also spent more than they received. ${ }^{1}$ Municipal loans in that year stood at nearly $£ 3,000,000$. The Sydney Bulletin, ${ }^{2}$ having severely scrutinized the State accounts, has the following free remarks to make of the municipalities:

The New South Wales alderman has just as little idea of getting his town hall out of pawn as J. Carruthers has of getting his State out; and almost the greatest sinners of all are the suburban mayors and aldermen, who shouldn't exist at all, and who shouldn't be possessed of any town halls to pawn. These suburbs owe $£ 764,8$ rg, besides overdrafts, and, ruling out Marrickville and Ryde, all that the

1 The Statesman's Year Book, 1906.

2 September 7, 1906. 
whole thirty-eight of them put up last year in the way of sinking fund was $£ 397$. Ryde and Marrickville put up $\ell_{1}, 400$ between them. This precious crowd, nevertheless, paid $£ 34,04 \mathrm{I}$ in interest. Here and there a suburban council paid off an odd hundred or two, mostly because it was squeezed into it, or because a bailiff arrived and threatened to stay; but, as a rule, when the councils paid $£_{1}$ they borrowed $£^{2}$ IOs., so the situation got worse instead of better. The Sydney suburban mayor's and alderman's idea of honest and decent finance can best be reckoned by the fact that, though thirty-nine of the suburban municipalities are in pawn (the fortieth is in pawn, but only on an overdraft) no more than four of the whole shiftless, drifting crowd have sinking funds for the systematic repayment of their debts.

I am aware that the Sydney Bulletin-a journal possessing considerable influence-is regarded by many as occasionally expressing rather extreme views on questions affecting public administration, and as being somewhat prone to be 'agin the Government.' At the same time, all who are acquainted with Australia must allow the truth of the principles it demonstrates-principles not to be affected by the mere over-emphasis the Bulletin finds it necessary to employ to drive home its point.

The neglect of the authorities named to provide sufficiently for the amortization of their capital expenditure on their undertakings only illustrates the close resemblance of their accountancy methods with those of British public bodies. In the case of the New South Wales railways and tramways, which are State properties, the policy followed, sanctioned by the prece- 


\section{THE DANGERS OF MUNICIPAL TRADING}

dents afforded by other States, is not to write off capital at all, and there is, accordingly, no sinking fund. Revenues are therefore lightened of an item the presence of which in the accounts would diminish the net profitor, if a deficit, would add to it.

The recent financial history of Western Australia is thus surveyed by the same journal ${ }^{1}$, and, it may be added, the substance of the criticism is confirmed by many of the far-seeing banking and commercial authorities in the Commonwealth :

The State has had a royal time for about sixteen years, and that time shows signs of not lasting for ever. In I89I Westralia owed only $\ell_{30}$ per head of a very small population; now it owes $£ 67$ per head of a much larger one. There have been some years when the amount borrowed equalled the amount raised by all forms of taxation. There were one or two gorgeous years when the amount borrowed, if it had been divided equally among the population, would have enabled everybody to live in a humble but honest fashion without doing any work at all. In a handful of years Westralia exhausted most of its borrowing powers, and it has now to go very slow in the matter of loans. The railways in 1896 , at the summit of the boom, were alleged to yield II $\frac{1}{2}$ per cent. profit-largely through charging repairs to loans; this was down to $4 \frac{1}{2}$ per cent. by 1899 , and is now only about $3 \frac{1}{2}$ per cent. Westralia learned so thoroughly how to have a good time that in 1898 it had a revenue of nearly $£ 17$ per inhabitant and spent nearly $£ 20$. Other States could live on a revenue of $£ 6$ or $£ 8$ per head, and even scratch out a surplus; Westralia had got into such an imperial frame of mind that it spent a revenue of $£ I 7$ and had over $£ 500$,000 deficit on top thereof. Of

1 September 7, 1906. 
course this incredible revenue couldn't last; the gold is fading, the loans are fading, the days of riotous eating and hilarious drinking and the times when nobody's accounts were audited and nearly everybody helped himself, are passing away.

It is not possible to read these extracts from responsible statesmen and newspapers without realizing that the dead-lock of debt now holding down Australia is due to a deep-seated demoralization of public life. Financial chaos has been more or less rife for the past twenty years; it arose from the moment the initiation of a ruinous public-works' policy was made, and will continue while, to echo the words of Mr G. H. Reid, leader of the Opposition in the New South Wales Parliament, "the seat of a man in Parliament depended upon how much money he could abstract from the public treasury for carrying out works in his electorate in the most reckless and improvident fashion.'

Australia at the beginning did great things by the pursuit of a policy of freedom promoting, as in the mother-country, before municipalism developed, unhampered scope for individual energy. It is the more remarkable, therefore, that its people should have allowed the firm establishment of Socialistic principles, which predicate a mistrust of an individual's power to manage his own affairs. No programme such as has been outlined could otherwise find support or adoption. Consciously or unconsciously, a people which upholds the State as a fetish has no belief in itself as a com-

1 Sydney Morning Herald, April 4, igo4. 


\section{THE DANGERS OF MUNICIPAL TRADING}

munity of persons. After becoming a great colony, founded on individual liberty, Australia has transferred its allegiance to an impersonal abstraction-the Stateobsessed by the idea that the State can better continue and finish what the individual began. Democracy and bureaucracy are as wide as the poles asunder; yet Australia has tried to blend them.

How has this paradoxical pursuit of a policy of extreme democracy, side by side with an extreme disbelief in the wisdom of the individual, justified itself in the vicissitudes of the colony? It lacks population; the birth-rate is shrinking; there is a total lack of immigration. Here we have a large slice of the planet's surface, only a little less in area than the United States, within whose boundaries whole kingdoms could be packed, whose natural wealth and climatic conditions are unsurpassed, which could easily support a population of I00,000,000 souls, yet so little used and so nearly vacant, withal so rich and tempting, that, after $\mathrm{I} 20$ years of colonization, its population is no more than that of the London suburbs.

It is argued that increased immigration would not add to the prosperity of the country, and that it might tend to hasten the period of adversity which is predicted; it may be added, that in such a period the existing labour and Socialistic legislation would make bad worse. At any rate, I am informed that the Australian labour classes-which control the legislation-do not consider that an expansion of population would be to their advantage. Leading politicians in New Zealand, also, 
believe it to be better for the individual that the present relation between the population and the country's resources should continue. That this belief is an erroneous one may be judged by the contrary experience of the United States, where immigration is proceeding at the rate of $\mathrm{I}, 000,000$ a year, where there is, nevertheless, a great dearth of labour, where wages are high, and where also prosperity has reached a standard as great as any yet attained in Australia.

The domination of the Labour Party is clearly responsible for the stopping of the clock of progress in Australia. Socialism has created a national selfishness and exclusiveness which may be likened to the once obstinate insularity of China. Like China, Australia fears the foreigner, whether he be of its own or any other colour. The pursuit of the narrow ideal of a Socialistic community, protected by a legislative wall, wherein the individual is extinct, and the State all-inall, is hardly favourable to the realization of Tennyson's dream of the 'Parliament of Man, the Federation of the World', towards which, it is charitable to believe, the nations of the earth would slowly move as the centuries pass if, in their progress toward that goal, such social diseases as at present afflict Australia and are incipient in other countries could be exterminated. 


\section{CHAPTER V}

\section{THE REFLECTIONS OF OTHER MINDS}

$\mathrm{HE}$ condition of Russia and Australia proves the
folly of acting upon the principle of 'no finality to municipal enterprise.' England will have more difficulty in finding the safe road than will the United States - that is, if America can only hold municipal ambition down to the non-profit-producing undertakings. $\mathrm{Mr}$ John Boyd Thatcher, when Mayor of Albany, once said, when speaking on this subject: "If the city may do those things for the individual which he cannot do for himself, may it do for him those things which he finds it inconvenient to do for himself ? If it may care for his safety and health, may it also care for his morals and his comforts? If it may build him an academy to educate a sound mind, may it build him a gymnasium to develop a sound body? If it build him a gymnasium to train his muscles, may it erect an arena to test his prowess? If it publish police rules and regulations for his conduct, may it establish an ethical college to teach him the foundation of obligation? If it may teach him ethics, may it teach him religion? And may all these things be done at the public expense? Here our vessel 
breaks from its moorings and drifts toward the beautiful but dangerous coast of paternal government.' These words are quoted because they summarize the arguments with which we are met every day. Those who believe in and want Paternal Government and Socialism frankly tell us that they favour the whole Socialistic programme -that a city should conduct all functions, from the worship of the Almighty down to the manufacture of toothbrushes. Those who do not believe in Socialism, and yet persist in enlarging the sphere of municipal trading, should realize that, by the destruction of individual effort, they are rapidly undermining the very foundations of their country's strength and greatness.

The State's function is to give every man an opportunity to do business under a stable government. The question will be asked : 'Is it safe to trust municipalities to do all these things at the public expense ?' In spite of the cry, 'No finality to municipal enterprise', there will be finality when, as $\mathrm{Mr}$ Thatcher suggests, the vessel of Municipal Trading 'breaks from its mooring and drifts toward the alluring but dangerous coast of paternal government.'

Russia and Australia seem to have hesitatingly drifted to that extreme. Are the United States and the United Kingdom prepared steadily to drift in the same direction? Are we even prepared for the German system of centralization? Even if it is possible to show that the experience of many cities proves that Municipal Ownership and management of common services may be successful and of immediate advantage to the public 
under some conditions, does that close the case in favour of Municipal Trading ? Far from it. Is not this advantage reaped at the expense of the future? Do not the economic undertakings of governments only emphasize the failure of governments to govern? Herbert Spencer has told us that every additional State interference strengthens the tacit assumption that it is the duty of the State to deal with all evils and secure all benefits. I have shown that in Russia increasing power of a growing administrative organization is accompanied by a decreasing power of the rest of society to resist its further growth and control. It was said of Count Witte, when Finance Minister, that he loved industry, but he loved patronage still more, and, if two officials could do the work of one, so much the better. The infinitely elastic revenue would provide for them, and the more officialdom means more government and less peoplewhich illustrates precisely the general principles laid down by Spencer when he says :

The people at large, led to look on benefits received through public agencies as gratis benefits, have their hopes continually excited by the prospects of more. A spreading education, furthering the diffusion of pleasing errors rather than of stern truths, renders such hopes both stronger and more general. Worse still, such hopes are ministered to by candidates for public favour by countenancing them.

Mr Shaw strenuously advocated such errors, it might be said, when he submitted: 'And if the English citizen chooses to supply himself with electric, pneumatic, or 
hydraulic power, light railways or tramways, stores for municipal paving or forage for municipal horses, cottages and block dwellings, light and heat, with fittings and stores, and, indeed, any commodity whatsoever, at cost price, with capital costing only three or four per cent. on the joint credit of himself and his fellow-ratepayers, he must not be forbidden.' This is exactly the same argument that was used by Count Witte in relation to the Russian citizen, realizing that this municipal enterprise was destined to play admirably into his hands.

The limits of the province of government have been clearly defined by John Stuart Mill in his Principles of Political Economy, and were they observed by presentday governments, the evils which follow in the train of the policy followed by Count Witte, and approved by Mr Bernard Shaw, would not exist. 'The true reasons', says Mill, ' in favour of leaving to voluntary associations all such things as they are competent to perform, would exist in equal strength if it were certain that the work itself would be as well, if not better, done by public officers.' These reasons he thus states: 'The mischief of overburdening the chief functionaries of government with demands on their attention and diverting them from duties which they alone can discharge to objects which can be sufficiently well attained without them; the danger of unnecessarily swelling the direct power and indirect influence of government, and multiplying occasions of collision between its agents and private citizens; and the inexpediency of concentrating in a dominant bureaucracy all the skill and experience in 
the management of large interests, and all the power of organized action, existing in the community-a practice which keeps the citizens in a relation to the government like that of children to their guardians, and is a main cause for the inferior capacity for political life which has hitherto characterized the over-governed countries of the Continent, whether with or without the form of representative government.'

Mill concedes, however, as we all do, that voluntary associations should not perform their work entirely uncontrolled by the government. 'The community needs some other security for the fit performance of the service than the interest of the managers; and it is the part of government either to subject the business to reasonable conditions for the general advantage, or to retain such power over it that the profits of the monopoly may at least be obtained for the public.' He also holds that in the event of a State becoming the proprietor of canals or railways, they will almost be better worked by a company renting the railway or canal for a limited period from the State.

Long before Mill, another great thinker-Baconsaid: 'Of ambitions, it is less harmful the ambition to prevail in great things than to appear in everything, for that breeds confusion and mars business '-a truism which, it has been suggested, should be inscribed over the entrance to the new hall of the London County Council, and, with equal propriety, might appear outside the town hall of every municipality in the United Kingdom as pointing the way to true local government. 
If Bacon's sage advice is to be ignored, we may ask, with the Hon. Charles N. Lawrence, speaking at a meeting of the Imperial Industries Club held in London ${ }^{1}$ ' On what altar is this hecatomb of the business community to be sacrificed? unto what end is this revolution to be effected? Private enterprise, it would seem, is to perish in order that the dreams of Karl Marx and Lassalle and Henry George may be realized, in order that the means of production and distribution and transit and what-not may become communistic property. These dreams are older than Karl Marx; these dreams were dreamed, and these fallacies confuted, long before the advent of the Christian era. In Plato's Republic is a sketch of a Socialistic State carried out with such ruthless logic that even the entire population of marriageable females was to be merged in the jointstock assets of the Commonwealth. Sparta was organized on a more or less collective basis, somewhat imperfect, it is true, in that a helot class had to be kept to do the work, and short-lived largely in consequence of this defect of its qualities. The likeness between those days and the present is not wanting. England also has a helot class, though they live in Park Lane; she also has a Lycurgus, ${ }^{2}$ though he hails from Battersea; and $\mathrm{Mr}$ Bernard Shaw's "Superman" seems cast for the rôle of a latter-day Plato. But if the fallacies are old, so also is their confutation. Let me read a short extract

1 Railway News, Nov. I8, 1905.

2 The reference is to $\mathrm{Mr}$ John Burns, President of the Local Government Board. 
from the well-known passage in Aristotle's Politics, in which, with the incisive common-sense of his wisdom, he criticizes Plato's Socialistic proposals. It has a direct bearing on the question of municipal ownership. $\mathrm{He}$ points out that what is everybody's business is nobody's business, and says: "A maximum number of owners involves a minimum of care for the joint property. People pay most attention to their private concerns; for those which they have to share with others they care less, or, at any rate, only to the extent to which each has a personal interest therein; for, apart from all other considerations, they are apt to neglect such business, on the supposition that someone else is attending to it, just as in domestic service the more servants you have the less efficiently the work is generally done." '

Reverting to Mill, such a state of things has also drawn him, in his well-known work On Liberty, to speak of the consequences of a State or of a municipal government minding everybody's business. His observations cannot be too often quoted. 'Every function', he says, ' superadded to those already exercised by the government, causes its influence over hopes and fears to be more widely diffused, and converts, more and more, the active and ambitious part of the public into hangerson of the government. If the employés of all these different enterprises were appointed and paid by the government, and looked to the government for every rise in life, not all the freedom of the press, and popular constitution of the legislature, would make 
this or any other country free, otherwise than in name.

'To be admitted into the ranks of this bureaucracy', he continues, 'and, when admitted, to rise therein, would be the sole objects of ambition. Under this régime, not only is the outside public ill-qualified, for want of practical experience, to criticize or check the mode of operation of the bureaucracy, but even if the accidents of despotic or the natural working of popular institutions occasionally raise to the summit a ruler, or rulers, of reforming inclinations, no reform can be effected which is contrary to the interests of the bureaucracy. Such is the melancholy condition of the Russian Empire, as shown in the accounts of those who have had sufficient opportunity of observation. The Czar himself is powerless against the bureaucratic body.'

Finally, let me quote a philosopher and statesman who is with us to-day, and who, by his distinguished career, is more qualified than most to obtain a clear perspective of the course whither modern municipalism is tending. I refer to $\mathrm{Mr}$ Balfour. When Prime Minister in I903, he advocated, and Parliament subsequently ordered, the appointment of the second Select Committee to inquire into Municipal Trading to which I have more than once had occasion to refer. 'I should like', he said in the House of Commons in the course of the debate arising therefrom, ' each individual member of the House to ask himself this question, among others : Can we view with absolute serenity an indefinite increase in the position of the municipality as an employer 
of labour among its own constituents ? I do not feel absolutely sure of that. I know something about the phenomenon as it affects this House. I know that there are no questions more perplexing and more dangerous than those which arise when members are returned to this House by constituents paid by the State. I know that that is a danger here, and it is a danger which makes me look with great suspicion and dislike on any very large extension of employment by the community as a whole. What is a danger in this House I am convinced may be a danger to municipal bodies, and they may be tempted by the pressure of their own constituents to a course of action which may not be wholly for the common good. That is one danger, which, I think, ought not to be ignored by any man who looks at the question in the sober light of dry reason.'

Again, speaking of the speculative risks of these commercial undertakings which municipalities are assuming, Mr Balfour said: 'Can anyone feel the same kind of certainty when you leave road-paving and water-supply, and come to such matters as gas-supply-in which, I admit, municipalities have been conspicuously successful ? Can anybody say with certainty that gas, even in the near future, will retain its place as a source of light and heat power? I am not sure of it. When I come to such things as tramway expenditure, my doubts increase. With the great changes that are now going on in road locomotion, who will say that a fixed line of tramway-embarrassing as it is to every other form of 
street locomotion-is to be permanent, and the form in which you can best get improved transit from one part of a great city to another, still less from the centre to the outskirts? I do not look with absolute confidence upon the future of these enormous commercial undertakings in which the municipalities have been engaged. If you leave these matters to private enterprise, and inventions render antiquated the works upon which vast capital has been expended by a private company, what happens? The company becomes bankrupt or winds up its affairs, and a new and improved system takes the place of the old system. But supposing a municipality has embarked an enormous amount of the ratepayers' capital in improved transit, such as an overhead electrical system-or let it be granted that the municipality may have spent its money wisely at the time on whatever may be considered the most advanced form of electrical transit-then suppose that a method far better and cheaper is invented, how painful would be the dilemma of these authorities ! Are they to confess that they have wasted millions of the ratepayers' money in the past, and are they to reconstruct their works? Or are they to saddle their municipalities for all time with methods and inventions which are old-fashioned and worn out ?'

Here Mr Balfour touched upon the underlying fallacy on which British municipal trading is based. The ordinary councillor indignantly repudiates the term 'Municipal Trading.' Trading implies risk, and he will acknowledge no risk. His professed policy is simply to 
deal in permanently standardized methods of supplying public necessaries, and he makes no allowances for the diabolical restlessness of human invention. If he could have a fore-glimpse of the development of electric lighting, for instance, he would certainly never have gone into the gas business a generation ago. Again, many towns would have cheerfully left electric lighting to private syndicates if their governors had known what a fierce competition the cheap English gas was going to be when the introduction of the Welsbach incandescent burner and mantle came about. Our municipal trader will, in short, go into anything likely to yield a present profit or a future voter. This artless and bland acceptance of the present as an eternal fixture, and the utter lack of intelligent anticipation, are always deluding the British municipalist. $\mathrm{He}$ started to run tramways on the distinct understanding that this was merely a means of conveying passengers from the city to the near suburbs, and he is seriously annoyed to find now that his little scheme of lines and cars is liable to become little more than a side-track of an interurban transit company.

It will be seen that $\mathrm{Mr}$ Balfour, in his reference to municipalities undertaking transit schemes which may have this inglorious fate at the bidding of ' constituents' paid by the State (otherwise municipal employés), points to a danger which did not escape the observation of Spencer and Mill in their day-a danger very manifest in Great Britain at the present time. 


\section{CHAPTER VI}

\section{A POWER TO BE RECKONED WITH}

T $\mathrm{HEN}$ we come to reflect that in countries like the United Kingdom and the United States, a bureaucracy such as described by Mill would, unlike the Russian system, stand or fall by the votes of those ' hangers-on ', we have to realize the possible outcome of the bestowal of voting power upon an undesirable class. Russia, in her blind way, having once honeycombed and linked up her vast provinces with a subtle system of officialdom, has been wise enough to see that the only chance of its preservation lies in confining power to the upper and withholding it from the lowest stratum of society. The sole justification for the repression of her masses lies in her belief, right or wrong, that power is not likely to be more abused if vested in the superior classes than if exercised by the proletariat. There is the same human nature at both ends.

Municipal traders in other countries overlook that unalterable fact. The ultimate fate of British municipalism as it is now shaping depends upon the course it will take when once it is entirely at the mercy of the Socialists, who, as much swayed by cupidity and love of personal power as the feudal lords of old, are moving, 
and will continue to move, heaven and earth to capture its administrative machinery. The rising of the masses is a frequent event in the history of nations; but one does not read of the rising of the classes above them. The English property classes are hardly likely to take lying down the gradual confiscation of their belongings, which is threatened by the Socialistic legislation the future promises, if signs and omens are to be read aright. The form their revolt takes would constitute a unique page in history. But to do justice to the pioneers of modern municipalism, they started on their voyage of expropriation with no deliberate design of doing harm to other people's interests. They were merely obsessed by the belief that municipalities had a divine ordinance to perform certain things at which they had never tried their hands. They were overcome by a spirit of self-assertiveness; their selfdevelopment created a form of public egotism, as it were, which, unremittingly exhibited, duly clashed with the activities of private corporations energetically engaged in the very objects the municipality desired to monopolize. Their intentions, it is true, were well meant. But they blundered sadly in failing to see the outcome of their new policy. When, some years ago, Sir Albert Rollit, the president of the Municipal Corporation Association, declared that municipalities disclaimed any intention to trespass on the legitimate province of the private trader, he spoke too late. This mischief had already been done. The ownership policy, once started upon, as I have already shown, awoke the 
Socialistic party into feverish activity, for they discovered that here, at last, was a valuable part of the armour of society which they could pierce with success. It drew in their mesh the legitimate working man with his trade unions, and all the incapables of his class, added to the submerged tenth beneath it. By the accession of such voting strength-obtained by methods which I shall presently describe in more detail-the remaining taxpayers, on whom the whole burden falls, have been numerically outclassed, even if they voted to their full complement, for, overwhelmed as they are by the legions of non-taxpaying voters ranged against them, they too often neglect to vote. There are many examples in British industrial cities of one class (the masters) providing the money whilst another class (the men) elect how it shall be spent. It explains the 'popularity' of Municipal Trading in Great Britain. The class that supports it is not the class that pays. It is a popularity which wirepullers can very easily create. He that pays the piper does not call the tune. To the poorer population of any town exempt from direct taxation, the spectacle of an ostentatious street railway system, with the municipality's title emblazoned on the cars, or of an ornate electricity works which supplies power only to a section of the community, whilst all the taxpayers contribute to its upkeep, whether electricity is used by them or not, conveys a sense of personal ownership (to which they have contributed nothing)a pleasurable feeling that it is 'ours '-that they live in a go-ahead town. The impression so created, added 
to the fact that popular judgments are largely guided by official utterances, is a potent influence in securing their votes at election-time, apart from the anxious canvassing of the trading party.

The winning over of the less responsible of the population to an approval of the ownership principle by according them the enjoyment of all manner of privileges, results in an over-municipalized city, in which the taxpayer, as individual or trader, does not count, and only the working-class voter matters. Glasgow is a typical instance. There 'a citizen may live in a municipal house; he may walk along the municipal street, or ride on the municipal tram-car, and watch the municipal dust-cart collecting the refuse which is to be used to fertilize the municipal farm. Then he may turn into the municipal market, buy a steak from an animal killed in the municipal slaughter-house, and cook it by the municipal gas on the municipal gasstove. For his recreation he can choose amongst municipal libraries, municipal art-galleries, and municipal music in the municipal parks. Should he fall ill, he can ring up his doctor through the municipal telephone, or he may be taken to the municipal hospital on the municipal ambulance by a municipal policeman. Should he be so unfortunate as to get on fire, he will be put out by a municipal fireman, using municipal water ; after which he will, perhaps, forego the enjoyment of a municipal bath, though he may find it necessary to get a new suit in the municipal old-clothes market.'

1 R. E. C. Long, Fortnightly Review, January, 1903. 
The government of any city, conducted on these lines, brings us back to a consideration of the hangers-on, the satellites, and the pickers-up of crumbs and unconsidered trifles who cluster round a local authority which seeks to be a universal provider. Of such the employé is the most important, because his numbers and voting power are growing, and his collective strength may one day develop him into a creature so huge that his creators will be unable to hold him in restraint. Even now municipal candidates nervously acknowledge his voting strength, and ko-tow to him. The manifest social danger of giving such power to a class of men who are necessarily of an inferior calibre in mind and character (since they are the product of an inferior environment) means-if it comes to no worse-that in the course of time municipal employés will rule the local council, and not the council the employés. They will choose their masters, who will be at their dictation. Notable supporters of Municipal Trading are so alive to this danger that they strongly advocate the disfranchisement of every man dependent for livelihood on his employment by a municipality. The present complexion of the British Parliament, however, does not hold out any prospect that this is likely to occur. Municipal employés, like their masters, are aware of their power. They have an organization numbering 2,000,000. A little while back, Mr Keir Hardie, leader of the Independent Labour Party (a portion of whose programme, by the way, is to give municipalities power to sell coal, bread, milk, and dairy and farm products), 


\section{THE DANGERS OF MUNICIPAL TRADING}

discovered this fact, and regarded the dimensions the organization had reached as 'very interesting', especially as they represented I4 per cent. of the total wageearners in Great Britain, who now number 14,000,000. This leader of labour congratulated them on the fact that in I903, when there was a reduction of wages all round, the wages of municipal employés alone had increased-it might be said, had even doubled. Public men (Lord Avebury among them) are constantly drawing attention to the enormous influence which municipal employés can and do exert at local elections for purely personal objects. As a matter of fact, the Municipal Employés Association offers, as an inducement to municipal servants to join it, the wonderful influence at municipal elections which they would be able to exercise. And, indeed, local authorities, in their anxiety to purchase their loyalty, dangled cherries in plenty for them to bite at. 'Every committee proposal put forward by the governing body offers a temptation to the workpeople to grasp at a momentary advantage, and to let the future take care of itself. In this manner it substitutes individual for corporate welfare as the motive of the working-class voter, and so the patriotic ideal is overmastered by self-interest, and the democratic judgment is poisoned. In his civic capacity our Constitution expects a voter to be altruistic ; communism tempts him to be egoistic.'1

The creation of such a privileged class of employés in the United States would undoubtedly constitute a

1 Dixon H. Davies. 
similar menace to the public weal. Reflect for a moment what an organization like Tammany would become if, to its present force of officials, an army of industrial employés should be added. In Great Britain their power is particularly felt because of the small percentage of the other electors who go to the poll at municipal elections. The average is well under 50 per cent., and is rarely above. The London County Council rejoices in 35,000 employés, and for the whole London area there are 60,000 men in the municipal service-a large proportion of whom occupy municipal dwellings. The electorate in London for municipal purposes in 1905 numbered 742,000. As no more than half, generally less, exercise their vote-say 371,000 - the 60,000 votes of the municipal employés represent nearly I7 per cent. of votes recorded. For, whoever abstains from voting, it is not the municipal employé. If, however, he should lack ardour in recording his vote, then he is assiduously whipped up by anxious candidates and their aldermanic supporters. At a Birmingham municipal election not so long ago, this was done so shamelessly that even the Daily Neros-a leading organ of municipalization-was moved to protest. 'Even the City Council', it remarked, 'were not immaculate in their practices. It was not dignified to see leading municipal officers marshalling bands of corporation workmen into the polling area and explicitly instructing them to vote for the Bill.' (The occasion was a referendum to the citizens as to whether the municipality should take over the street railways.) But, as a rule, 


\section{THE DANGERS OF MUNICIPAL TRADING}

municipal employés need little egging on, organized as they are, and thoroughly imbued with the importance (to them) of perpetuating and developing the ownership idea to the length of its tether. The Times, in its repeated warnings, thus sums up this phase of the tendency: ' In every municipality there will be a large body of voters and ratepayers whose interest it will be to encourage and promote expenditure, who will be certain to unite, and will be able, when united, to carry their points. When once a municipality has set up an establishment for carrying on any industry it will be no use trying to undo the mistake, if such it prove to be. Municipal hands cannot be turned adrift. Employment must be found for them at the expense of the ratepayers, and in due course they will agitate for pensions, and, in the end, get them. It will go ill at the next election with anyone who suggests that they be discharged because they are useless, or that expenses should be cut down.'

Before dealing with this question of pensions, it must not be forgotten that beyond the permanent employés of municipalities, whose positions are their safeguard at the expense of the taxpayers, is a large straggling class of loafers and ne'er-do-wells, with, maybe, a sprinkling of genuine unemployed men, who are given temporary employment by local bodies, which they accept on a promise of favours to come. The method of providing work for these men is one which, whether designed or not, undoubtedly affects the working-class vote in favour of the trading policy. It is a form of 
municipal charity known as 'relief works', which are not undertaken because they are wanted, but because there are a number of unemployed wanting work. They have no other purpose, and their promotion gives a wholly artificial complexion to the industrial activities of a district. One class is living as vagrants, upon another, which pays for work that may be likened to the ploughing of sands, for all the benefit the community as a whole derives from it. It is as though an impecunious householder were forced to employ a man to paint a house which did not require painting, himself the while feeling the pinch of paying for work done which benefited neither him nor the house, but only the worker. It was stated in the House of Commons by Mr Gerald Balfour ${ }^{1}$, when the late Unionist Government was in power, that for at least twenty years local authorities had been giving employment relief at the expense of the taxes. I will quote his exact words, which are full of meaning: 'On this point I think it is well that we should rid ourselves of all illusions. When a local authority puts in hand a public work and engages on that work persons who are avowedly unfamiliar with it, simply because they are unemployed, the local authority is undoubtedly giving relief, and giving it at the expense of the rates, to the extent to which the cost of the labour actually employed exceeds the cost at which the labour would have been provided by a contractor. If the work is useless, it is clear that the

1 'Debate on Unemployed Workmen Bill,' the Times, June 21,1905 . 
entire sum so spent by the local authority is spent in relief. I have no doubt that in the last twenty years there has been a considerable expenditure by public authorities on works of useless and costly character.' According to a return presented to the House, a sum of something over $£$ III,O0o was spent in the winter of I904 by the metropolitan authorities on works undertaken specially for finding work for unemployed workmen. A fairly generous estimate may be made if the value of the work then done, circulated in wages alone, is put at a little over $£ 80,000$. From a return made by eighty-nine of the largest towns in the United Kingdom, in January of I905, in seventy-four out of these eightynine places the local authority gave relief employment, and the men employed at that time or another in the provinces numbered 2I,000. In London during the same month 20,000 or 21,000 men were employed; therefore, the local authorities were employing, without disfranchisement, and at the expense of the rates, about 4I,000 men. As to the cost of the same work in the provinces, the information is meagre; but in five towns alone-Manchester, Salford, Leeds, Bradford, and Sheffield-about $£ 36$,ooo was spent on employment of this kind during the winter named.

The question arises, To what extent may masses of the unemployed feed on the taxes by being given work which is unremunerative, and has no other object? Sentiment may answer that it is humanitarian, and so it would be if the means adopted did not empty one man's pocket to fill another's. The people so helped 
do not pay rates. In London, out of 703,000 rate assessments levied in I90r, no fewer than 309,500 were in respect of houses and tenements the rates of which presumably are paid by the house-owners, and not by the tenants, and it is among this class that the people who are given this sort of employment are to be found.

The more far-seeing and steady of the unskilled and vagrant class hold on to municipalities as drowning men clutch at straws, in the hope of permanent employment, and that obtained, they help to swell the dimensions of the already vast army of the labouring class who by their vote already threaten to dictate to local authorities what policy they shall pursue. They have old age in front of them, and once safely berthed in the municipal port, will see to it that they are not then turned adrift.

Here arises another aspect of the general question of municipal employes, indicated in the quotation made from the Times, which involves the piling up of additional obligations on future generations. We are confronted in the first place with the automatic rise in the scale of pay of municipal officials and workpeople; and, in addition, gradually, but certainly, other classes of workpeople and their superintendents are, like them, qualifying for pensions or 'superannuations-schoolteachers, policemen, poor-law officers, gasworkers, tramway men, and so forth. For example, the pension list of the London County Council for I906-07 is estimated at $£ 64,095$, as against $£ 26,769$ in I889-90. I am assured that no sufficient provision is being made to provide the capitalized value of these accruing pensions, and 
that some day English ratepayers will wake up and find obligations representing twenty-five, perhaps fifty, millions sterling, for services which were given to a previous generation. These pensions are growing by leaps and bounds in Australia. Obviously, the continued growth of municipal employés increases this danger. In Australia constitutional government has been paralyzed, and a Trades Hall Party has become all-powerful without responsibility. Increase of wages and lessened hours of work have resulted in individual stagnation. The abuse of the Early Closing Acts, it is said, is also responsible for a large amount of distress among the small shopkeeping class. Every reduction in the hours of employment has been accompanied by an increase in the rate of wages, which is handed on to the customer in the shape of increased prices and charges.

The end in Australia, or in England, if Municipal Trading continues unchecked, will be precisely the same as the end of Count Witte's policy in Russia-the demoralization and impoverishment of the people. The fact that the mechanism is worked differently does not alter the results. Count Witte, when Russia's Finance Minister, set in to train a vast bureaucratic system, which is only a somewhat magnified edition of that of the British municipalist and the Australian labour leader. They are all working tooth and nail for the same end-namely, the establishment of a vast fabric of State ownership and State patronage for the benefit of those who hold the power, and whatever 


\section{A POWER TO BE RLCKONED WITH IO}

agency controls these industries, whether State or municipal, whether the strings are pulled by a 'silent gentleman in a frock coat ' in St Petersburg, or by a committee of municipal socialists in the Spring Gardens, London, or by labour officials in Trades Hall, Melbourne, makes no difference. The results are the same. 


\section{CHAPTER VII}

\section{BRITISH LOCAL AUTHORITIES}

E AVING dealt with the municipal servant, the 11 municipal masters-councillors and officialscall for similar attention. Judged alone by their fitness to undertake Municipal Trading, irrespective of their qualifications as councillors and officials, we do not find their activities prove that the better the men the better the work, because, while the best class of business men are willing to give a reasonable amount of time to public matters, it is impossible to secure the same class of men to study and conduct intricate business, which must of necessity then fall into the hands of paid officials. The organization of a city council or of the committee of a city council does not lend itself to effective management of commercial undertakings. Their duties are too diverse for them to control large businesses efficiently, and, on the other hand, the personal responsibility is too vague to bring home to them the results of financial mistakes. The question has been asked, Who would purchase shares in a company the board of which was to be elected by its own employés? An increasing number of pro- 
fessional and business men feel they cannct give the time necessary to master the infinite details of large commercial undertakings, with the result that these grave responsibilities are relegated to men encouraged to enter local politics for very different purposes. The fact that there is at present a measurable degree of integrity and ability in the management of municipal affairs does not mean that it will always remain so. There was a time when English cities were as corruptly managed as some American cities have been in more recent years, and constant vigilance in such matters is as important on one side of the Atlantic as on the other. It is impossible to view with complacency a system of local administration which confides the control not merely of proper municipal work, but, to a large extent, of industrial local enterprise, to the hands of a bureaucracy. Here we have the baneful example of Russia being followed with fidelity. Of course such a shifting of the real work from the shoulders of councillors to those of paid officials is not to be wondered at if regard be had to the average personnel of the members of municipal councils and to the short tenure for which they are elected. The composition of a municipal council is always in a state of flux; it is a shifting quantity, whilst the staff of permanent officials remains constant. It would be unjust to question the personal abilities of many members of municipal bodies, but that admitted, it does not follow that they are able to conduct successfully outside undertakings. Many have realized this, and decline to accept places on the boards. 


\section{I04 THE DANGERS OF MUNICIPAL TRADING}

As a result, frequent changes take place, which is very bad for industrial undertakings, because it constantly puts men without experience of the particular industry in charge of the work. This undoubtedly accounts for such stupendous mistakes in estimating the cost of electrical undertakings, in which the actual cost has exceeded by threefold the original estimates given the board by the committee; and for the foolish and unnecessary losses in the experiment of Thames steamboats. That the extension of functions will end in lowering the standard of local legislators is not only my opinion, but the opinion of many disinterested and thoughtful Englishmen. It has been said with truth that the real rulers of the British Empire are the permanent Government officials at Whitehall, not the particular political party which, for the time being, has gained popular support. With equal force it may be said that the real local administrators in Great Britain are often the town clerk and his colleagues, who sway their councils with the success which superior experience commands. For this, judged from the point of view of their own self-interests, they cannot be blamed. Far from a local body 'instructing' their town clerk to take this, that, or other action, it is as often the case that the 'instruction' is a cut-and-dried matter which the town clerk has previously settled upon, and for the carrying out of which he formally obtains the endorsement of his council. Often they brush aside this fiction of 'instructing' their officials, and boldly state that they are 'acting upon' the 'advice' of their town clerk, 
or engineer, or other expert. To a municipal council, or the usual committees into which it is divided, to whom are delegated the conduct of different departments of municipal work, the paid officials often are guides, councillors, and friends. Of course, municipal officers are not all alike. Some have even been described as a compound of vanity, ignorance, and servility, too tame to be anything like so bold as to swing their council to their way of thinking. Officials of this type generally go through life consumed with the fear of an arrogant amateur committee-a committee composed of various cliques of tradesmen and labour men, who fight furiously for any credit that may be going, but try to shift the blame on the official. As the constitution of these committees is always subject to change after the frequent municipal elections, the official must always struggle to keep in the good graces of all parties, so that he has to be a Barnum freak of the 'boneless wonder' type, or else he loses his employment. There is undoubtedly a leaven of men of character among them, who are like faithful dogs leading their blind masters-instructors and shepherds of ignoramuses. But conceive of the directorate of a trading company absolutely depending for the success of its operations upon paid subordinates, who act on 'directions' they themselves have inspired, and generally rule the roost. Municipal councillors, however, cannot very well help themselves in this blind reliance in their officials, on account of the instability of their position, apart from their ignorance. In periodically running the risk of 


\section{I06 THE DANGERS OF MUNICIPAL TRADING}

losing their seats, they are unable to establish a permanent solidarity of policy with one another. Members of a private firm, on the other hand, enjoy a lifelong association. In the case of a company, a change of directorate does not interfere with its cohesion or policy. If the personnel of a firm were changed as often as is that of a municipal body, no business could be conducted successfully. Moreover, men serving for a period on municipal councils are not elected directly as members of a body established for trading purposes. That question does not come before the local electors as a separate issue. Candidates are elected by reason of their views on any question, local or imperial. Not much is heard at elections of the injustice of municipalities encroaching on the rights of individuals by competing with them as traders, with the public purse as their capital. One influence only, in the majority of cases, sends municipal candidates to the top of the poll, and that is their political views. They get through primarily as politicians, not as business men. In fact, as I have already stated, men who are accustomed to deal with large affairs and who understand the complexities of great financial arrangements, are not to be found to any extent on the councils of municipalities. They are, for the most part, engaged in undertakings similar to those carried on by municipalities, and cannot be expected to spend their time in competing with themselves. The services of these men, which would prove so valuable in the important legitimate duties of local government, are, therefore, lost to the country. The 
places which such men fill are taken by others, who are often unfitted to control the large interests entrusted to their care. The inevitable consequences follow. Expenditure is incurred, partly extravagant and unnecessary, because local authorities are frequently bad managers, even where they are not corrupt. They spend money on what is not really wanted, and more than they ought on what happens to be necessary. Heavy liabilities are incurred, and they burden the future light-heartedly. 'Expenditure', as Sir Robert Giffen $^{1}$ has well said, 'is pleasant to those who have a little brief authority, and the increase of the number of local authorities increases the number of those who enjoy that pleasure.'

Here it will not be amiss to glance at the social status of members of local bodies in England, in whom are vested powers to spend large sums of public money to an extent which, measured to their own personal means, are as a mountain is to a molehill. A few years ago a list was drawn up giving the occupations of the members of the Poplar Board of Guardians, and the Times, in the exhaustive inquiry into municipal ownership which it made in I902, and to which I have had frequent occasion to refer, analyzed this list. As conditions are much the same to-day, it will be instructive to show to what type of men belongs a board which annually spends over $£ 200,000$ of the public funds. One was a cooper rated on a rental of $£$ II a year; another, a jobbing builder, on $£ I 5$; a third, a polisher, on $£ I 6$; a fourth, a gas-

1 Contemporary Review, Vol. lxxxvii. 
stoker, on $£^{10}$; a fifth, an undertaker, on $£^{24}$; and a sixth, a gas man rated on a rental of $£$ I5 a year. Then there was a greengrocer, a confectioner, a baker, a fireman, a caretaker, a couple of publicans, and so forth, who were taxed on an assessment somewhat higher than those named; but in no case did a single member pay any taxes at all. They lived, in fact, in small houses, the taxes of which were paid by the landlord, so that here we have a body of men disbursing large sums of public money, to which they have directly not contributed a cent. Another instance of a district similarly governed is Battersea, fittingly described by the Standard as 'the cradle of advanced thought and a hot-bed of revolutionary doctrinaires.' Its local council, largely composed of working men, some of them even general labourers, is possessed of the idea that public money may be promiscuously spent for the benefit of all comers. This takes the form of building by direct labour, instead of employing private firms, luxurious recreation-rooms and museums, public libraries, gymnasiums, and workmen's dwellings, several of which institutions are wholly unnecessary, as the district is already provided with them. These enterprises, however, are merely entered upon to provide work for the army of local workmen which constitutes the voting strength of the Socialistic Council. The Council, naturally, being of the same class as their constituents, yield to the temptation to do their fellows a good turn, without troubling themselves about considerations of public policy. Added to these superero- 
gatory acts, the Council has built baths at an estimated outlay of $£ 38,800$ and an actual cost of $£ 56,000$, the loss on working which in I905 was over $£$ II,000. These ventures spring from the municipal 'works department', an establishment formed for the direct employment of labour by the municipality-a type of enterprise which usually spells expensiveness, often inefficiency, and occasionally scandals. The result is that every form of municipal enterprise which its Council has tried has ended in a dead loss, and, in many cases, in injury to Battersea traders.

Mention has already been made of the Association of Municipal Corporations, the deus ex machina by which members of Parliament are cajolled and coerced into supporting Bills which require legislative sanction for the purpose of spending untold sums on trading schemes. This powerful body spends enormous sums in opposing the projects of private companies requiring similar sanction on the ground that they conflict with the extension of Municipal Trading. This means, in effect, that the municipalities are continually seeking to deprive men (and their own taxpayers too) of the opportunity of working according to their own choice of employment. Lord Alverstone has called attention to the great influence exercised in Parliament by this association. The tender solicitude with which it watches all legislation affecting Municipal Trading, and the skill with which it can concentrate its forces at short notice in aid of legislation favouring Municipal Trading, and to defeat obnoxious measures, gives some idea of 
the cohesive power of self-interest-a self-interest which is dangerous enough when exerted from the outside in large combinations of capital, but which is far more disastrous to sound government when exercised from within by a strongly-welded organization of ambitious officials determined on extending their influence. To what extent the influence of this organization has been exerted to retard electrical enterprise, both in traction and lighting and power distribution it is impossible to say, but there is a general belief, founded upon some well-established facts, that England would have made much more headway in these industries had it not been for the deadening influence of organized officialdom. It is a bureaucratic ring so strongly organized in self-defence that it whips the member for a Scotch borough to vote against an electric power scheme for Ireland. No private scheme which touches, even remotely, the objects of modern municipalism is permitted to go through a parliamentary Committee without being strenuously opposed clause by clause by the municipalities en masse, represented by the counsel of the Municipal Corporations Association.

Such opposition is too vindictive to have as its object the desire to perform 'superior public service', or to relieve the taxes, by undertaking to carry out themselves what private enterprise is fully qualified, and, indeed, exists, to perform. It is not difficult to cast about for the real motive for their thwarting of private enterprise at every turn. However harmless were the beginnings of Municipal Trading, it has now developed into a thirst for power for power's sake. 
Municipalities want to be paramount. They are so protected by the law that they may with impunity steal a horse, whilst private enterprise cannot look over the hedge. Parliament grandmothers them in such a way that the merest approach of private enterprise on the preserves of any one municipality not only sends the local body concerned scurrying to Westminster to beat off the intruder, but with it all the other authorities from one end of the land to the other to lend support to their threatened brother. A trivial local question as to whether a railway company shall run motor omnibuses from its station in some small town is, therefore, opposed by all the local authorities in the kingdom in a body. The railway omnibus may take a few passengers from the municipal tramways, and that must not be suffered. Thus the schemes promoted by private enterprise for providing London with cheap electric power on a large scale have not only had to face the opposition of the London local authorities, but of every other authority. The batteries of the Municipal Corporations Association (with which they are nearly all affiliated) are turned on most schemes of private enterprise put before Parliament, and it is small wonder that the latter is becoming crippled all along the line.

By such tactics is it made clear that the inherent weakness of modern municipalization lies in its utter helplessness to face private enterprise in the open, and it has therefore to seek the shelter of legalized monopoly, and to prop itself up by compulsory subsidies wrung from the taxpayers in order to survive. 


\section{CHAPTER VIII}

THE BURDEN OF OWNERSHIP OBLIGATIONS

WITH such advantages in their favour, let us see how local governments have acquitted themselves. Public economy has been defined as a moral principle ; but as it is not generally practised by British municipalities, they lay themselves open to the accusation of flagrantly transgressing against one of the primary laws of good government. Masses of figures which illustrate the financial dangers of a country have only an academic significance to its inhabitants until they begin to realize that each of them is individually involved in the liability created by reckless State or municipal administration. At present the British municipal debt is increasing at the rate of $£ 30,000,000$ per annum, and on that reckoning it is highly probable that at present (I906) it has reached the sum of $£ 528,000,000$, or at the rate of over $£ \mathbf{1 2}$ per head of the population. On the latest published actual figures (for I903-04), as ascertained from the 'Statistical Abstract ' for the United Kingdom for I906, the British local debt stood at $£ 464,670,440$. If the United States increases its municipalized industries to the extent 
at present manifested, it will have a municipal debt exceeding that of the British by well over $£$ roo,000,000. In I904 the United States city debt was approximately nearly $£^{160,000,000}$ below the British local debt of 1903-04. The actual indebtedness of United States cities relating to municipal industries, however, bears approximately the same proportion to the whole sum as the amount raised for the same purposes by British municipalities bears to the total British debt-e.g. :

Local Debt.

United Kingdom. . United States
. . $£ 464,670,440$

. $306,292,53 \mathrm{I}$
Proportion sunk in Reproductive Under. takings (1903-4). £2I $5,100,454^{1}$ I 58, I I 4, I 45

But if the respective capital of the municipal water undertakings of both countries, about which there is no strong contention, be deducted, at once is seen the favourable position of American municipalities in respect of its trading schemes. The following figures show that only about a third of the British reproductive capital is represented by municipal waterworks, whilst well over two-thirds of the American productive capital is thus accounted for:

Capital of reproductive under-

United Kingdom. United States.

\begin{tabular}{ccccc} 
takings .. &.. & $\ldots$ & $£ 215,100,454^{2}$ & $£$ I 58, I I 4, I 45 \\
Less waterworks &. & $\ldots$ & $67,998,457$ & I I $2,219,474$ \\
\hline
\end{tabular}

1 An underestimate, ascertained as follows : England and Wales, $t_{1} 87,100,454$; Scotland (same year), estimated $£ 28,000,000$. No figures for Ireland.

'For 1900-or, vide Municipal Year-Book, 1906. 


\section{II4 THE DANGERS OF MUNICIPAL TRADING}

By thus excluding the non-contentious service of water, the American municipal reproductive debt is reduced to a figure more than a third below the British reproductive debt after being submitted to the same process.

It will be well to glance at the increase of the total local debt of both countries since I880 (when each was practically the same), to show the headlong pace at which it has advanced in the United Kingdom mainly through Municipal Trading speculations, and the moderate rate of expansion in the United States through this element not entering to anything like the same degree into local politics :

$\begin{array}{llllr}\text { Local debt in } 1880 & \ldots & \ldots & £ \text { I } 36,934,070 & £ \text { I } 36,869,768 \\ \text { Local debt in I890 } & \ldots & \ldots & \text { I98,67 I,3 I } 2 & \text { I44,852,6 I } 2\end{array}$

Here it will be seen that the British local debt advanced by over $£ 60,000,000$ in the decade instanced, or at the rate of $£ 6,000,000$ per annum. The American local debt, on the other hand, only expanded by $£ 8,000,000$ in the same period, or at only $£ 800,000$ per annum. In proportion to the population, which had grown 25 per cent. during the period, this small increase is really a decrease. For whilst the local debt per capita in I880 was fII 6s. 6d., by I890 it had been reduced to $£ 7$ IIs. $3 d$. per capita. In explanation of this decrease, it may be recalled that it was about this time that American cities were rescuing themselves from the burden of debt they were loaded with through their excessive zeal in the development of their districts, 
to which I alluded in the first chapter. To continue, confining the figures to recent years :

$\begin{array}{lllrr} & & & \text { United Kingdom. }^{1} & \text { United States. } \\ \text { Local debt in 1902 } & \ldots & \ldots & £ 407,453,935 & £ 261,960,272 \\ \text { Local debt in 1903 } & \ldots & \ldots & 437,622,235 & 285,168,317 \\ \text { Local debt in } 1904 & \ldots & \ldots & 464,670,440 & 306,292,531\end{array}$

The I902 figures, compared with those for I89o set out in the previous table, indicate that both the British and the American local debt in twelve years had more than doubled in the one case, and nearly doubled in the other. The rate of expansion of each is fairly uniform. Let us see what part reproductive undertakings had in the increased indebtedness of the years I902-03-04 in both countries, applying to the United Kingdom the official figures for England and Wales, and estimating the reproductive debt of Scotland and Ireland as standing at $£ 30,000,000$ in each year, for lack of exact figures :

Reproductive undertakings in

$$
\text { United Kingdom. United States. }
$$

I902 $\quad . \quad \ldots \quad \ldots \quad \ldots £^{189,761,278} \quad £_{115,925,813}$ Reproductive undertakings in

$\begin{array}{llllll}1903 & . . & . . & \ldots & 205,395,698 & 125,646,152\end{array}$ Reproductive undertakings in

$\begin{array}{llllll}1904 & . & . & . . & 2 \mathrm{I} 7, \mathrm{IOO}, 454 & \text { I } 58, \mathrm{II} 4, \mathrm{I} 45\end{array}$

If these figures be also compared with the total local debt shown in the last table, it will be seen that in both cases reproductive works account roughly for nearly

1 'British Statistical Abstract' (I906).

2 'United States Census Bureau Returns' (Bulletins 20 and 50 ). 


\section{II6 THE DANGERS OF MUNICIPAL TRADING}

half the increment, and that the ratio of their increase in both countries is approximately the same. But if, again, allowance be taken of the non-contentious element of water, which stands out as the chief service in municipal hands in the United States, the reproductive debt figures for the latter country admit of considerable reduction. Thus, of the reproductive debt in the United States in I902 ( $\left\{\right.$ II $\left.5,925,8 I_{3}\right)$, no less than $£ 75,436,8$ I5 represented capital sunk in waterworks; of the I903 reproductive debt ( $£$ I25,646,I52), water accounted for $£^{84}, 695,792$, or about two-thirds ; and of the $£$ I58,II4,I45 (I904), £II2,2I9,474, or over twothirds, as already shown, represented waterworks capital. In the case of the United Kingdom, there is no regular official return showing the part water undertakings take in the annual increase of the municipal reproductive debt; but it is improbable that the increase is mainly to be attributed to their growth. Their value in I900-or, as already stated, stood at $£ 67,998,457$, or about a third of the estimated reproductive debt of the following year (I902). It was not until I905 that any notable transference of water from private to public control took place in the United Kingdom, when the Metropolitan Water Board took over the works of the London water companies at a cost of $£ 37,474,522$. The conclusion to be gathered from the foregoing figures to I904 is that, so far as the United States is concerned, the increase in public ownership obligations is at present to be mainly attributed to water, as to the public control of which there is no great dispute. 
The following comparative table, showing the indebtedness of a group of representative American and British cities, whilst obviously favourable to the former, would be still more so if the element of water be borne in mind :

\section{American Cities. ${ }^{1}$}

City

New York

Chicago

Philadelphia

St. Louis

Baltimore

Cleveland

Pittsburg

Buffalo

Detroit

Milwaukee

Louisville

Minneapolis

Indianapolis

Kansas City, Mo.

Denver

Los Angeles

Atlanta

Albany

$$
\begin{array}{lr} 
& \multicolumn{1}{c}{\text { Debt. }} \\
& \multicolumn{6}{c}{} \\
. . & 88,066,981 \\
. . & 12,638,839 \\
. . & 12,965,556 \\
. . & 4,276,195 \\
. . & 4,721,021 \\
. . & 4,084,917 \\
. . & 3,738,925 \\
. . & 3,641,943 \\
. . & 1,093,564 \\
. . & 1,813,908 \\
. . & 1,565,498 \\
. . & 1,621,032 \\
. . & 953,229 \\
. . & 1,496,347 \\
. . & 843,469 \\
. . & 1,119,396 \\
. . & 659,223 \\
. . & 552,686
\end{array}
$$

Per Capita.

$£$ s. d.

22 I3 0

6 10 10

963

6 I 60

8 I 53

9 I 20

IO I 20

9 I 5 IO

380

$\begin{array}{lll}5 & 17 & 8\end{array}$

7210

$\begin{array}{lll}6 & 9 & 8\end{array}$

4 I3 0

8 IO 0

5 I 36

$\begin{array}{lll}9 & 5 & 0\end{array}$

$\begin{array}{lll}6 & \text { I3 } & 6\end{array}$

5 I4 0

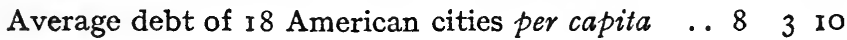

In order that the public may be brought to realize the necessity of confining their public-ownership operations within their present limits, it will be well to focus attention, without further comparison, upon the dangerous economical position in the United Kingdom,

1 'U.S. Census Bureau Bulletin,' No. 50. 
which has been reached by the pursuit of a contrary policy.

A committee of the Birmingham Chamber of Com-

British Towns.

City.

\begin{tabular}{|c|c|c|c|c|c|c|c|}
\hline London .. & $\cdots$ & - & $\cdots$ & IO3,237,454 & 22 & I6 & \\
\hline Glasgow .. & .. & .. & .. & I $5,492,495$ & I9 & 6 & \\
\hline Liverpool & - & .. & - & $14,556,592$ & 20 & 9 & \\
\hline Manchester & - & .. & . & $20,195,829$ & 32 & I & \\
\hline Birmingham & . & .. & . & I $5,504,675$ & 29 & I 3 & \\
\hline Leeds _.. & $\cdots$ & . & - & I I ,079,003 & 24 & 4 & \\
\hline Sheffield .. & .. & .. & .. & $8,165,824$ & 18 & Io & \\
\hline Bristol .. & .. & .. & - & $5,253,728$ & I4 & I 3 & \\
\hline Bradford & . & .. & . & $7,597,824$ & 26 & I 2 & \\
\hline Nottingham & . & .. & . & $6,466,04 \mathrm{I}$ & 25 & I 3 & \\
\hline Salford .. & .. & .. & .. & $3,456,508$ & I4 & I 8 & \\
\hline Bolton .. & . & .. & $\cdots$ & $3,534,319$ & I9 & I6 & 14 \\
\hline Oldham .. & . & .. & . & $2,833,980$ & 20 & 4 & \\
\hline Cardiff $\quad$. & $\cdots$ & . & $\cdots$ & $3,562,73 \mathrm{I}$ & 21 & I & \\
\hline Preston ... & $\cdots$ & -. & . & $I, 933,537^{2}$ & 16 & I 4 & \\
\hline Plymouth & . & .. & . & I,779,488 & I 5 & 6 & \\
\hline Huddersfield & $\cdots$ & . & $\cdots$ & $3,328,278$ & 35 & 0 & \\
\hline Blackpool & .. & .. & .. & $1,601,183$ & 29 & 2 & \\
\hline
\end{tabular}

Average debt of 18 British towns per capita $\ldots \begin{array}{llll}22 & \text { II } 3\end{array}$

merce, after a recent investigation into the causes for the great increase of imperial and local expenditure,

1 Municipal Year-Book, 1906.

2 ' $£$ I, 550,000 of Preston's debt sunk in Municipal Docks, and a further sum of $£ 200,000$ is to be or is being spent on them. Every year Preston taxpayers have to pay a sum of $£ 36,000$ to make up the deficiency.'-Lancashire Post, March 2, 1906. 
and its effect upon trade and industry; found ${ }^{1}$ that, whilst State expenditure exceeded that of local authorities up to the year I898-99, the expenditure of the latter has since that year increased by leaps and bounds, so that in the year r904-05 they estimated that the total expenditure of the United Kingdom was over $£ 30,000,000$ in excess of that of the State expenditure. In the year I88I-82, they report, " the total expenditure of the local authorities in the United Kingdom was $£ 66,665,499$, or $£$ I I7s. Iod. per head of the population. In the year I902-03 the figures were $£ I 52,165,000$, or $£ 3$ IIs. II $d$. per head, representing a total increase of nearly I29 per cent., and a per capita increase of a little over 90 per cent. Calculating the total expenditure during I903-04 and I904-05 on the rate of increase during the previous five years, we estimate that the local expenditure for I904-05 would be not less than $£ I 72,000,000$, or $£ 3$ I9s. $8 d$. per head of the population, representing a total increase of $5^{8}$ per cent. and a per capita increase of IIo per cent. The progressive increase of local expenditure did not become permanent until I890-9I, when it was $£ 70,734, \mathrm{I} 68$, or $£^{\mathrm{I}} \mathrm{I7}$ s. $6 \mathrm{~d}$. per head of the population, so that if that year had been taken as a starting-point, the increase per head of the population works out at a higher figure than that given above.' The Birmingham committee, it will be noted, hit upon the period when Municipal Trading really started upon its career in the United Kingdom. Here is their table showing

1 'Report on the Imperial and Local Revenue and Expenditure of the United Kingdom ' (1906). 
the expenditure of local authorities by aggregates for successive periods of ten years :

\begin{tabular}{|c|c|c|c|c|c|}
\hline $\begin{array}{l}\text { Decade year } \\
\text { ended } \\
\text { 3rst March. }\end{array}$ & & & & $\begin{array}{c}\text { Aggregate } \\
\text { Expenditure. }\end{array}$ & $\begin{array}{c}\text { Yearly } \\
\text { Average. }\end{array}$ \\
\hline I 882-I 89I & .. & .. & .. & $t^{666,070,072}$ & $£ 66,607,007$ \\
\hline $1884-1893$ & .. & .. & . & $693,319,174$ & $69,331,917$ \\
\hline I 890-I 899 & .. & .. & .. & $874,78 \mathrm{r}, 535$ & 87,478, I 53 \\
\hline $1894-1903$ & .. & .. & .. & I, I $30,646,888$ & I I $3,064,689$ \\
\hline
\end{tabular}

The expenditure during the ten years I894-I903, therefore, exceeded that of the decade I882-9I by no less a sum than $£ 464,576,816$, representing an average increase of $£ 46,457,682$ per annum. They calculate that if the difference between the yearly average of local expenditure in the decade I894-I903 and the yearly average of the decade I882-9I, as shown above, were invested in real productive works at 5 per cent. simple interest, it would produce over $£ 23,000,000$ per annum. The figures quoted are not such, in their opinion, as can be regarded by commercial men with equanimity, because the increased expenditure represents an ever-increasing burden which is felt more and more acutely by the business community, from whom the bulk of local revenue is derived. Local taxes levied in I902-03 were nearly $£ 25,000,000$ in excess of the amount for I890-9I; Government contributions to local services were more by nearly $£ 8,000,000$, and loans increased by $£ 31,000,000$. They attribute some portion of the increased expenditure of the local authorities to Municipal Trading operations; but it must, nevertheless, be borne in mind, we are pertinently 
told, that these have not been instrumental in reducing local rates. On the contrary, they add, a closer examination of the figures would reveal the disquieting fact that the extension of Municipal Trading has been accompanied by an accelerated increase in local rates and Government contributions.

The growth of local taxation can best be indicated by the expansion in local revenue generally, which the Birmingham Chamber of Commerce Committee also critically examined. In the year I88I-82 they showed that the revenue of the local authorities of the United Kingdom from all sources amounted to $£ 67,705,079$; whilst in the year I902-03 (the latest year for which detailed statistics are officially published), it was $£$ I52,29I,000, representing an increase of I25 per cent. in twenty-two years. Per head of the population the amount of local revenue in I88I-82 was $£ I$ I8s. $6 d$., as compared with $£ 3$ I2s. in I902-03, an increase of over 87 per cent. per head. During the five years previous to I902-03 the local income of the United Kingdom increased at the average rate of over $£$ I0,000,000 per annum, so that the estimated income for the year I904-05 would be $£$ I72,000,000, or $£ 3$ I9s. $8 d$. per head, representing a total increase since I88I-82 of over I54 per cent., and a per capita increase of I07 per cent.

The same story is to be told of assessments. The Local Government Returns (for I903-04) show that the total taxable area of the United Kingdom was assessed in $1874-75$ at $f I I 5,646,63 I$; whilst in I902-03 it was 
£IgI,I06,528, an increased taxable value in thirty years of $£ 75,459,897$.

The enormously increased financial involvements of local authorities can be seen from the following percentages, taken from the same official source:

Increase in amount of rates raised between 1874

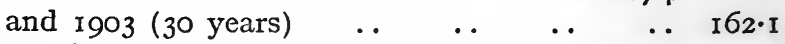
Increase in assessment value of taxable properties

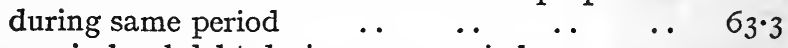
Increase in local debt during same period $\ldots \quad$. . $\quad 299^{\circ} 3$ Increase in local expenditure between $1884-85$ and

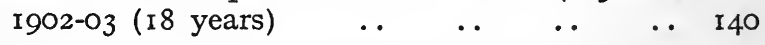

For the purpose of illustrating how heavily these increments bear upon the community, I append a table prepared by Mr J. Holt Schooling ${ }^{1}$, who takes the first three heads of increase between I874 and I902, and shows how they worked out per capita in the years named :

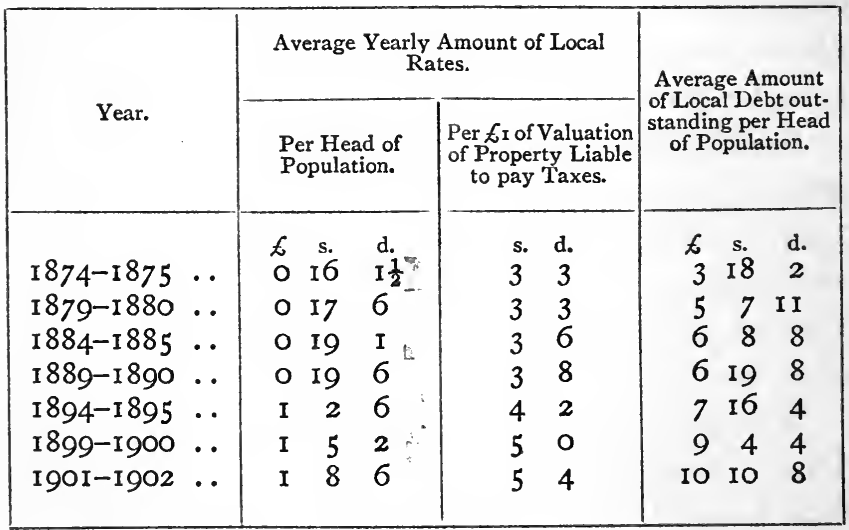

1 'Local Finance' (Fortnightly Review, August, 1906). 
Here we find the two sources from which are drawn the increased local revenue-a continuously expanding tax-levy side by side with an enhanced valuation of taxable property. The higher taxes per $£$ I are charged upon an increased assessment of property. Of course, a local authority that wants more money from the citizens may fall back on ringing the changes. Hesitating to raise the taxes, it has only to increase the assessments in order to obtain the desired extra revenue, or it may raise the poundage without tampering with the assessments. But the figures show that, as a rule, it boldly does both.

To the above table may be added the per capita increase of local expenditure, to which resort is made to these devices, as figured by the Birmingham Chamber of Commerce Committee in the years they cover :

\section{INCREASE OF LOCAL EXPENDITURE.}

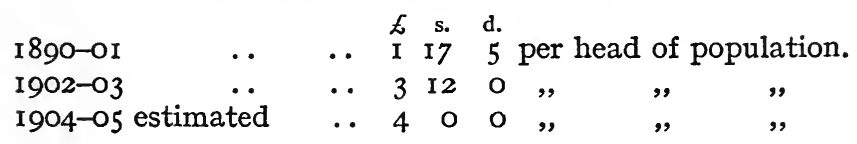

The foregoing leads one to suppose that the many spending authorities of the United Kingdom (to quote Mr Schooling) are apparently possessed by the idea that the taxpayer is an inexhaustible golden goose which lays the golden eggs, and they, reckless of consequences, are busily engaged in killing that bird. Wedged in between the municipal councillor and official and the untaxed voter, is this golden goose-the long-suffering citizen and the group of long-suffering citizens (trading 


\section{I24 THE DANGERS OF MUNICIPAL TRADING}

companies) who have to pay for the whims of the one and the privileges of the other. It must be conceded that the British taxpayer, singly and collectively, allows a great deal of license to his municipality. But he cannot very well help himself-he does not represent the larger proportion of the municipal electorate of the British Isles. This disability rises from the social injustice of the franchise laws, which ordain much taxation without representation, and much representation without taxation. Corporate bodies, such as railway companies, and, in fact, all limited liability concerns whose contributions to local taxation form an enormous sum, do not possess a municipal vote, and are therefore denied any voice in the disposal of the money they pay to their local authority. Quite a common example of this state of things is that in certain towns one single company, or a group of companies, are the largest taxpayers, and their taxes form the chief part of the whole income of the borough. On the other hand, their employés, with a voting qualification, constitute the main numbers of the population of such manufacturing towns, and live in houses of so low an assessment value that they are exempt from taxation. The Midland Railway pays one-eighth of all the taxes of Derby, and, moreover, its lines run through 800 parishes, to each of which it pays its quota of taxes. One shipbuilding company pays one-sixth of all the taxes at Jarrow. There is also a colliery company which pays nearly the whole of the taxes of one township, whilst the colliers, who pay nothing, can vote down the 
one or two officials at the colliery and the few farmers and shopkeepers in the neighbourhood. None of these companies has a single vote.

Some official figures recently published, which have been strikingly amplified by $\mathrm{Mr}$ Dixon $\mathrm{H}$. Davies, illustrate this injustice to British corporations and companies. They refer to half a dozen selected boroughs (named below), and from both these sources I have compiled a table which shows the taxable value of the companies' properties; the proportion it bears to the taxable value of the whole borough; the number of non-voting companies; the number of voting taxpayers ; the whole taxable value per head of the voting taxpayers, and the taxable value per head of the taxpaying companies who have no vote:

\begin{tabular}{|c|c|c|c|c|c|c|}
\hline Borough. & 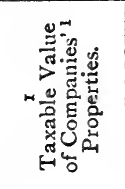 & 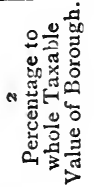 & 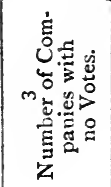 & 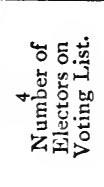 & 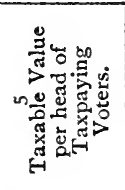 & 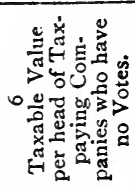 \\
\hline Birmingham & $\frac{\stackrel{f}{809,044}}{8}$ & $280^{\circ}$ & $2,04^{8}$ & 100, 698 & $\begin{array}{cll}t & \text { s. } & \text { d. } \\
20 & \text { I3 } & 0\end{array}$ & $\begin{array}{c}\qquad \\
395\end{array}$ \\
\hline Leeds & $55^{\circ}, 674$ & $26 \cdot 6$ & 1,365 & 84,043 & $18 \quad 2 \quad 0$ & 403 \\
\hline Liverpool .. & $I, 480,42 I$ & $32 \cdot 4$ & $\begin{array}{c}\mathrm{I}, 264 \\
\text { estimated }\end{array}$ & I IO, 742 & 2717 & $\mathrm{I}, \mathrm{I} 7 \mathrm{I}$ \\
\hline Manchester & $x, 317,360$ & $32^{\circ} 0$ & 3,007 & I03, 857 & 2619 & $43^{8}$ \\
\hline Sheffield .. & $537, \mathrm{I} 8 \mathrm{I}$ & $30 \cdot 1$ & $I, 320$ & 78,722 & I5 I6 & 406 \\
\hline West Ham & 449,297 & $34 \% 7$ & I9I & 40,070 & $2 I 00$ & 2,352 \\
\hline Holborn & 315,737 & $30 \cdot 6$ & 625 & I2,OI 7 & 59 I 0 & 505 \\
\hline
\end{tabular}

1 Assessed on the estimated rental value.

I, 2, and 3, Local Government Board Returns (No. 215 of 1906). 4, 5, and 6, Mr Dixon H. Davles. 
Thus we see that between a third and a fourth of the taxable property from which each of the boroughs named draw their revenue has no voting representation because it happens to be owned by companies, whilst the taxable value per head of taxpaying voters shrinks into insignificance compared with the taxable value per head of the taxpaying companies who have no votes. These examples are typical of the position of incorporated private traders in all the municipalities, and indicate the enormous sum which is annually extracted from them by local authorities without let or hindrance.

In the case of the railway companies there is double injustice inflicted, for the taxes they pay are in part spent in constructing and running street-railway systems to compete with their services, which sometimes actually run parallel with the railway lines. These municipal street railways are often run at a loss; as taxpayers the railway companies have to meet their proportion of that loss, and, at the same time, have to suffer a shrinkage in their own traffic through the diversion of much of it to the municipal tram-cars. The aggregate amount of local taxes paid by British railways is no less than II per cent. on their net revenue, or I per cent. on their total ordinary stock. The following figures show the growing disproportion between the taxes paid and the increased earning power and capital value of the lines:

I894.

Net revenue $\ldots \quad £ 37,100,000$

Capital raised.. 985,000,000

Taxes paid .... 2,816,000

$\begin{array}{rr}\text { rgo4. } & \begin{array}{r}\text { Increase in } \\ \text { Decade. }\end{array} \\ £ 42,660,000 & \text { I 5\% } \\ 1,268,000,000 & 28 \% \\ 4,736,000 & 68 \%\end{array}$


Whether traffics are good or bad, the ratio of working expenses to receipts high or low, the total income from all sources great or little, the upward movement of local taxation levied on companies continues, unaffected by the pendulum swing of their working.

But the community hardest hit are the householders of the thrifty class, whose surplus income is limited by the necessities of their families. The large wealthy companies are content to pay and complain, for the injustice of being regarded as the milch cow of the municipalities is more bearable than the outlook of ruin which is the nightmare of struggling shopkeepers. Local taxes, so many shillings in the pound, come round every year, and must be paid, often by those who can ill afford it, and paid, too, for industries, such as electric lights, telephones, workmen's dwellings, harbours, and docks, and a score of other things in which the persons taxed have no earthly interest. In Birmingham, quite recently, twenty-five members of the Balsall Heath Ratepayers' Association preferred to be summoned for non-payment of taxes as a protest against reckless municipal expenditure. According to the press report of the police-court proceedings, the defending attorney said that the time had gone by when taxpayers could be led like sheep, not to the slaughter, but to be shorn without protest. They felt that the City Council was led away by a policy of so-called efficiency, and in the opinion of his clients no policy could be efficient unless it was founded on justice and economy. During the last sixteen years the indebtedness of the city had in- 
creased from seven to fifteen millions sterling, and every child born in the city owed a debt of $£ 30$, which it had done nothing to contract. 'We have been taught to think imperially', said the taxpayers' attorney, ' and we have, perhaps, lost the focus of local matters, and seem to forget that any imperial prosperity in the world must depend largely upon local prosperity.' Having publicly lodged their protest in this way, the objectors consented to orders for payment being made against them.

By the Public Health Act of 1875 British municipalities have their borrowing powers limited to two years' assessment value. A city, therefore, whose taxable property in one year is assessed at $£ 200,000$, cannot borrow more than $£ 400,000$ on the security of the taxes. But by obtaining special parliamentary powers, local authorities manage greatly to exceed this limit, and thus involve every child born within its area with a liability from its birth. Liverpool's debt is 300 per cent. over and above the security-i.e., the taxable value-or a debt equal to three years thereof; while Huddersfield has the heaviest percentage of anynamely, 730.23 per cent., or a debt exceeding seven years' taxable value. Stockton's is the same; Blackburn's debt is 575 per cent. over its annual assessment value, or five and three-fourths years; and in seventeen other principal towns the borrowing covers not less than four and one-fourth years of the taxable value.

It has already been shown that a large proportion of the local debt of the country is incurred for trading enter- 
prises alleged to be productive, and defended on the pretext that they yield profits for the relief of taxation. This fact, while patent enough from the general figures previously quoted in this chapter, projects with greater force if we observe how, in a number of municipalities, the extent to which ownership and trading enterprises are indulged in to determine the amount of indebtedness and the ratio of taxation, so that both are high where trading is largely practised, and are low where it is kept within limits. Thus, the tendency of debt and taxation in seventy-eight boroughs in England and Wales, as they stood in I903, may be gauged from the following:

In eleven towns where the proportion of 'reproductive' debt was under 50 per cent. of the assessable value, the average local taxes (excluding the poor tax) was only 26 per cent. on the assessment.

In sixteen towns where the proportion of 'reproductive' debt was between 50 per cent. and 100 per cent. of the assessable value, the average local taxes (excluding the poor tax) was 27 per cent. on the assessment.

In twenty-five towns where the proportion of ' reproductive' debt was between Ia) per cent. and 200 per cent. of the assessable value, the average local taxes (excluding the poor tax) was 28 per cent. on the assessment.

In twenty-six towns where the proportion of ' reproductive' debt was over 200 per cent. of the assessable value, the average local taxes (excluding the poor tax) was 30 per cent. on the assessment.

The conclusion is self-evident, and were it necessary to comment further upon the involvements with which British municipalities are encumbering their communities, one need only echo what the famous French 
economist M Leroy Beaulieu recently wrote: 'Local loans in England often total forty millions in one year, whereas in France it is rare for half that sum to be raised. This enormous and colossal borrowing by localities in Great Britain fills us with amazement in France, and seems to us to be the weak point in British finance. Undoubtedly England has benefited from the money spent on the educational system, the hygienic conditions have improved; but it seems impossible to account for the fantastical growth of local expenditure without allowing for some exaggeration and waste. The policy adopted in many towns of systematically municipalizing services of common interest is the point which astonishes us most. There is no doubt that in these days extravagance is more to be feared in municipal than in national finance.' 


\section{CHAPTER IX}

THE WORLD'S GREATEST SPENDTHRIFT

$\mathrm{T}$ order to drive home the lesson conveyed by the 1 statistics relating to municipal debt, taxes, and assessments just dealt with, it is necessary to turn from the general to the particular. For this purpose an examination of the trading exploits of any one of the English provincial cities would suffice, inasmuch as they are all more or less alike in their loose and unbusinesslike methods, and it would not be easy to single out one particular city as a worse offender than the others on a general indictment. But overshadowing them all in the magnitude of the Municipal Trading schemes carried on within its immense area stands the Metropolis, and in being distinguished from them in this, as well as in size, population, wealth, and other characteristics, London provides a scope for municipal maladministration which no provincial city can hope to eclipse. This is not surprising, as its inhabitants, through their electoral apathy, have, up to within the last few months, allowed themselves to be at the mercy of the central authority (the London County Council), the minor authorities (borough councils), and a host of 


\section{I32 THE DANGERS OF MUNICIPAL TRADING}

other spending bodies. The first-named body thereby had become known as the world's greatest spendthriftin fact, as one critic has expressed it, ' to view Municipal Trading at its best, or at its worst, we must concentrate our survey on the London area.'

The spending authorities of London have succeeded in incurring a debt to the year I904-05, as already mentioned, of $£^{\text {I0 } 3,237,454}$, or, roughly, of 254 per cent. over and above its taxable value. If we estimate that the whole British local debt in the same year, according to its present ratio of increase, stood at $£ 522,000,000$, it will be seen that London's share of it is nearly one-fifth. Of this debt of $£$ ro3,237,454, $£ 45,297,6$ I9, or 46.8 per cent., was incurred in respect of tramways, workmen's dwellings, water-supply, electric lighting, and other services. The total annual charge for the year I904-05 for interest and repayment in respect of the total net debt amounted to $£ 2,206,8 \mathrm{I} 6$, of which as much as 74 per cent. was met out of the taxes, and the balance, 26 per cent., from the 'earnings !' of revenue-producing services. The total debt has increased by $£ 4 I, 998,928$, as compared with an increase of $£ 3,306,425$ in the previous year.

This great addition to the debt has been brought about by a further expansion of ownership obligations in the establishment of the Metropolitan Water Board, which took over the water undertaking from the companies for the sum of $\{37,474,522$. It is no part of the writer's purpose to question the expediency of transferring water from private to public control. But it 
has to be commented in passing that this latest example of the expropriation policy has resulted in the people of London having to pay more for their water. Here is a typical criticism of the transaction": "There were three classes concerned. The shareholders in the expropriated companies, the ratepayers, and the consumers. The shareholders are as nearly as possible as they were, being given an equivalent in public stocks of the value of their former holdings. (They have, however, been transferred from persons engaged in an industrial enterprise to mere bondholders taking no risk, nor caring greatly whether the undertaking is profitable or not, so long as the taxpayers' property is good for the annual interest. The working under public management shows no profit at all, so the ratepayers are no better off.) The consumer gets the same water as before, the only difference is that he has to pay a little more for it, and is loudly complaining in consequence. The pretence is that a monopoly has been suppressed. Yes, and another monopoly, that of the authority, set up. King Log is replaced by King Stork, with the difference that there was the authority to control the water company, but who is there now to control the authority ?'

If the amount of the new debt incurred in respect of the purchase of the water undertakings $(£ 37,474,522)$ be deducted from the whole debt of London ( $£$ I03,237,454), we have a debt of $£ 65,762,932$, created by the other

1 Unconstitutional Tendencies of Local Government (Dixon H. Davies). 


\section{I34 THE DANGERS OF MUNICIPAL TRADING}

London authorities, for $£ 58,022,189$ of which the principal spending bodies are answerable-e.g. :

London County Council debt .. $\quad \ldots \quad \ldots \quad \ldots 45,234,198$ London Borough Council debt .. $\quad$.. $\quad$.. $\quad$ I2,787,991

$58,022,189$

The balance $(£ 7,740,743)$ may be allocated to the smaller authorities, such as boards of guardians, into whose administration trading, as understood, does not enter.

Of the County Council net debt of $£ 45,234,198$ at March 3I, I906, shown above, according to Lord Welby (then chairman of the Council's Finance Committee), $£ 6,687,366$ was remunerative, or 'reproductive.' In other words, this latter sum represents the amount of money the then Council, according to its chairman, has sunk in trading schemes-in steamboats, tramways, electricity, and housing. But the Council were not content to leave it at that. At the end of 1905 they were committed to further capital expenditure of $£ 6,000,000$ for tramway extensions and electrification (which makes

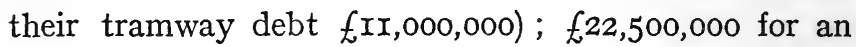
electric-supply undertaking, covering an area of 380 square miles; and $£ 2,234,000$ for further working-class dwellings (which brings the Council's housing estate to $£ 5,000,000$ ). Here we have a certain addition of $f_{12,734,000}$ to the present capital involvements in trading schemes $(£ 6,687,366)$, making a total of $£$ I9,42I,366, exclusive of considerable sums to be, or being, spent in street improvements necessary solely on account of the 
tramways. So certain are modern tramway systems over main routes within the Metropolis to yield large earnings, that it is to be expected that even municipal services will occasionally show conspicuous returns. The problem before the public, however, is to evaluate the profit as evidenced by rate reduction, and to discover by how much this profit could be increased by placing the tramways in the hands of private competitive companies.

The failure of the Council to run a service of steamboats on the Thames-a pet scheme they took up with great enthusiasm-is well known. A capital sum of $£ 304,000$ has been spent on them. The loss on working for nine months ending March 30, 1906, was nearly $£ 5$ I,300, whilst the estimated deficit for the year I906-07 is $£ 52,000$. So that ever since the service has been municipalized it has taken approximately $£ 200$ a week out of the pockets of London taxpayers. In a period of four weeks $£$ II,000 had represented the expenses and $£ 5,400$ the receipts. Put briefly, $£ 2$ had been spent on the municipalized service, whilst only $£^{\mathrm{I}}$ had been earned. Before the hapless municipal steamboats were inaugurated, some of the leading spirits of the Council speculated freely as to the 'profits' which would be derived therefrom for the benefit of the taxpayers. Sir E. Cornwall, ${ }^{1}$ then chairman of the Rivers Committee, thought they would yield $£ 90,000$ per annum. Indeed, he went further, for he believed 'that a greater

1 'Report of the Rivers Committee to the Council', January, 1902. 


\section{I36 THE DANGERS OF MUNICIPAL TRADING}

success would follow the undertaking than ever the most sanguine councillors anticipated-that, in fact, the undertaking offered startling possibilities of success.' Before the Parliamentary Committee which sat in May, I903, he improved on this augury by saying that the Council felt confident that the service would at once earn $£ 98,960^{1}$. Mr John Burns, before the same Committee, was less sanguine. $\mathrm{He}$ was reported as saying that he did not think the loss would be more than $£ 6,000$ or $£ 7,000$ at the outside. It was also submitted on behalf of the Council before the same Committee that 'the loss, even if there was a loss at all, would be a very small one, and that the charge upon the rates would be so slight as to be absolutely inappreciable.' Well, so far, the charge upon the rates (taxes) consequent on the Council running steamboats has proved to be a third of the capital spent, or froo,00o. The Council have acknowledged their defeat by discontinuing the winter service; but, of course, capital charges, cost of officials, etc., are still accruing.

In the working of the Council's tramway system, as will be shown, a great loss will fall upon London taxpayers through the Council not continuing to lease the more prosperous portion of the system (the Northern), instead of deciding to work it themselves. In the chapter on 'Profits' an examination has been made of the tramway accounts to show that nearly the whole of the sum placed in relief of taxation has come from

1 The Times, May 9, 1903. 
rents received by the Council from the leasing company. So far the experience of municipal tramways in London amounts to this : that the Council, on deciding to expropriate a tramway system, sacrifices, at the start, a rental which could be exacted from the company, for the chance that the system may succeed, on municipal operation, and yield a small profit. The difference between the large rental and the small profit, therefore, constitutes a wholly unnecessary loss. As far back as r896, before the Council could obtain ownership of the major portion of the Northern lines, they were at loggerheads with the North Metropolitan Tramway Company. The lines of a smaller company in the north of London had about then been purchased by the Council. As the North Metropolitan Company's lines had been built up piecemeal and at different times, the whole system could not become purchasable under the expropriation clause of the Tramway Act of 1870 en bloc, but in sections, as the franchise of each expired. The Council would have to buy it up bit by bit. Three suggestions for settlement were at length draftednamely :

(I) The North Metropolitan Company offered to lease from the Council the lines of the smaller system, and work them in conjunction with their own until I9IO, to which year, from 1896 (fourteen years) the company were to pay an aggregate sum in relief of taxation amounting to $£ 463,907$.

(2) The Council to purchase the company's lines as the leases fell, and relet them to the company on leases to expire in I9I0, the relief of taxation by this arrangement for the fourteen years being estimated at $£ 326,962$. 
(3) The Council to purchase and work the lines themselves at an estimated relief to taxation during the same period of $£ 28 \mathrm{I}, 305$.

These proposals showed that the leasing system promised more profit to the taxes than would have resulted if the Council had purchased and worked the lines themselves. In the end (I897) the Moderate section of the Council succeeded in getting the second proposal adopted, and the lines became municipal property, and leased to the company, the leases to expire in I9Io. In April, I906, they acquired the Northern lines from the company for the sum of $£ I, 095,469$. In addition, they are spending $£ 3,500$,000 on converting them from horse to electric traction. Apart from the speculative nature of this extra outlay, in view of the powerful opposition of the motor omnibuses, and the fact that it will yield no return for some time to come, a considerable loss has been thrown on the taxes by the company being bought out before its time. By IgIo it would have paid the Council, as rent, etc., a sum of $£ 326,962$ on the leasing arrangement made in 1897 just referred to, of which sum, up to I905, £I9I,995 was paid. As the company then ceased to exist, and as there are no more contributions in aid of taxation coming from that source, there was, therefore, a loss to the taxpayers of the difference between $£ 326,962$ and £I9I,995, or $£$ I34,967.

Under the lease the company paid the Council an annual rental of $£ 45,000$, and an additional $12 \frac{1}{2}$ per cent. of the increased gross receipts, as compared with 
the gross receipts in 1895 . Here are some conditions embodied in the lease, which conclusively show that the interests of the travelling public and the tramway employés were fully safeguarded, and that, under municipal working, the public will not be given a better service :

(I) The company are not to raise the fares on Sundays and Bank Holidays.

(2) The company are to run workmen's cars between 3 and 8 a.m., whenever the Council may require them to do so, at Id. fares for the whole distance, with a 2 d. return ticket available at any time. (A similar obligation the Council forced on the Central London Railway and on other lines, with the result that the latter run their workmen's trains at a great loss. On the other hand, the Council only recently objected to workmen riding on their own cars at reduced fares, and attempted to raise them. The Council, therefore, wring concessions from railway companies on behalf of the working classes which they themselves in running municipal tram-cars are not disposed to grant.)

(3) The company are to work any new lines that may be made by the Council, and pay the Council eight per cent. per annum on the cost thereof until midsummer, I9IO.

(4) The company are not to increase the hours of labour nor reduce the rates of wages of their employés.

(5) They are to pay rates and taxes on the value of the lines.

(6) They are to work the lines by electric or other traction, if and when required by the Council, and on most advantageous terms to the Council.

(7) They are to lay down at their own cost, when required by the Council, a mile of tramway for the purpose of experimenting as to the suitability of any improved system of traction.

(8) They are to set aside a sum equal to $£$ I2,500 a year 


\section{I40 THE DANGERS OF MUNICIPAL TRADING}

as a fund to be applied for renewals or reconstruction of the lines, which they are to keep in good condition, to the satisfaction of the Council.

In view of such restrictions and control, which the company faithfully respected, it is not clear to what degree the public will be benefited by the transference of the lines to the Council.

There remains a word to be said regarding the general tramway schemes evolved by the Council. The total amount of capital expenditure of the undertakings, including sums already incurred on lines opened for traffic, or to be incurred on others in prospect, was, up to the year I906, fII,000,000. It may be thought that such an outlay represented a considerable mileage, but actually it is only the ultimate development of a system comprising I2I miles of double track. This means approximately the investment of a sum of $£ 2,000,000$ in order to provide eleven miles. One wonders, with Engineering, if any tramway system in the kingdom, or in the world, can rival this achievement. 'If that were to be the end of all expenditure on tramway matters ', remarks that journal, 'one might be inclined to say: "The money's spent, and there's an end of it ; least said, soonest mended." But we are not nearly at the end, if all these extensions are to be promoted, and the ratepayers of London may well ask what will the total expenditure be when the Council's Highway Committee is at length satisfied ?' Happily, by the subversion of the 'Progressives,' a check has temporarily been put upon the immediate squandering. 
The system remains, however, and unless it is reformed altogether, it will assuredly arise within a few years in a shape more impoverishing than ever.

There was, indeed, no end in sight to the vaulting ambitions of the London County Council. Closely connected with its tramway policy was the scheme for obtaining a municipal monopoly for the supply of electricity in bulk over the London area. This is dealt with elsewhere. ${ }^{1}$ The development of its wasteful housing schemes in suburban areas ${ }^{2}$ is also an offshoot of its tramways extensions. In course of time the whole working - class population, snugly housed in municipal dwellings on the outskirts, were to be carried to and from their place of occupation in municipal tram-cars, and by the extension of both dwellings and cars their place of occupation would, in the natural course of events, have been probably the Council's Works Department.

The trading aspect of the problem has been ably dealt with in a series of special articles by a correspondent of the Times, recently published in collected form as The Story of the London County Council. In respect to the financial manœuvring of the Works Department, that writer declares that 'the object was to make the results appear more favourable than they actually were; those responsible for it had been driven to this device by the failure of the department to answer expectations. They had, in fact, acted up to the Progressive principle that the end justifies the

1 See chapter on 'Electric Light and Power Monopoly.'

2 See chapter on 'Housing.' 
means, and had practised a little manipulation of figures, by which no one was robbed, to serve the good cause.' Moreover, by excluding the private tender system from their scheme of municipal works they cut themselves adrift from all that could check their rapacity.

Why and wherefore the London County Council is able to conduct its Works Department on methods which only mean that when work is not offered for tender, but is carried out by this department, it is really given to the highest bidder-that is, the Council itself-is picturesquely explained by Mr Bernard Shaw, who, whilst a supporter of the Council's policy, is not adverse to playing the part of the candid friend. The Council, he says,

'goes to many an unfortunate wretch grimly struggling with poverty in a little shop, underfed, underclothed, underhoused, and consequently desperately in want of more money to spend on himself and his family. Taking him by the scruff of the neck, it says to him, "Come ; you must invest in the general prosperity of this magnificent Metropolis, of which you are-or ought to be-proud to be a citizen. You must no longer cross the Thames in a wretched penny ferry-boat; you must build a colossal Tower Bridge, with splendid approaches; or you must pass underneath in tubular triumphs of modern engineering. You must no longer walk through slums from the Strand to Oxford Street; you must make a new and lordly avenue, flanked with imposing buildings. And you must cheer yourself up with parks and bands, and run delightful steamboats on the river for your recreation on summer evenings." Is it any wonder that the unhappy victim of this comprehensive civic patriotism turns savagely on his Progressive benefactors, and asks them whether they suppose his name is Carnegie, or Pierpont Morgan, or Rothschild, that he should 
be forced into the schemes of millionaires ? And the irony of the proposals is the more biting as he well knows that if the improvements happen to affect his own business beneficially, his landlord will take the first opportunity to appropriate the increment by putting up his rent. This grievance is one which cannot be argued away, and cannot without gross callousness be disregarded. ... We have no right to force on people conveniences that they cannot afford. When a municipality which can borrow at less than 4 per cent. deliberately extorts capital for public works from tradesmen who have to raise it from Io per cent. to 40 per cent., or even more, it is clearly imposing the grossest unthrift on its unfortunate constituents.' 1

But what, it may be asked, would have befallen the ' unfortunate wretch, underfed, underclothed, and underhoused ', if the Socialists, who were foiled in their attempt to capture the Council at the March election of I907, had succeeded in materializing their programme, a few items of which are : Municipal workshops, stores, milk, and bread shops, and dairy farms ; free travelling for workmen to and from work ; municipal coal stores and collieries; municipal farm colonies for the unemployed (paid for by a direct tax on income derived from private industrial concerns); and municipal clothing factories?

The 'Progressive' policy pursued by the London County Council was naturally a direct incitement to the promotion of such a Socialistic programme. The same may be said of the record of the borough councils of the Metropolis. These go their own way under the statutory powers they enjoy, though the County Council

1 The Common-Sense of Municipal Trading, chapter x. 


\section{I44 THE DANGERS OF MUNICIPAL TRADING}

watch them with a supervising eye. In the main, they have been animated until recently by the same ambitions as were the Council. The latter body hold them in check, not so much from considerations of public policy as from a desire to keep their wings clipped, lest they should mount heights equal to, and even exceeding, those which the Council have already reached. The borough councils are impatient of the interference and authority exercised by the County Council; whilst the latter, with octopus-like tendencies, resent their very existence. The superior authority was, in fact, accused of an endeavour to acquire the whole administrative machinery of the minor bodies, including their trading undertakings, and of a wish to centralize the vast work of governing the entire Metropolis from Spring Gardens, thus absolutely abolishing ultimately the borough councils altogether. Jealous of the powers of the local councils to build luxurious libraries, baths, and washhouses, model dwellings, and electricity works, the central authority regards these as so much game which should fall to them, and not be divided between twentyeight other bodies. Perhaps the borough councils have deserved the ill-will of the higher authority. The latter they were really created to checkmate, and were invested with powers which otherwise the Council would doubtless have acquired. Hence the thorn in the side of the Council; these powers prevent the Council from realizing their desire to be, not the paramount authority, but the only authority for London.

The abolition of the borough authorities and the 
transfer of their functions to the Council would only mean that the taxpayers' eggs would all be placed in one basket. The failure of Woolwich, Bermondsey, or Marylebone to conduct an electric-lighting undertaking would not involve a loss confined to the taxpayers of those districts, as at present : the loss would be shared alike by all the other districts. There are numberless unprofitable and comparatively unused borough baths and washhouses-built on the fallacy that if a local authority provides these establishments the people would become clean-and the losses on these would be similarly distributed. London, in population, though not, of course, in area, may be classed with an American State, and the counties and townships of the latter with the borough divisions of London. An American township would resent having to pay for follies committed by another township. At the back of the London County Council's scheme of centralization to bring the whole area of London under their sole jurisdiction were their deeply-laid plans for developing their municipalization policy, to which the borough councils are often an obstacle. Indeed, the County Council have only been able to extend their tramways through the good-will of the borough authoritieswhen they can obtain it. The latter, if they elect, can exercise the veto they possess of keeping out tramways from their areas altogether. Chelsea, for example, has for some years past barred the County Council from running cars in the district. Holborn also opposed the Council's projected extensions through its territory. 
As the Progressive party of the County Council have declared that they must stand or fall by their tramway policy, to oppose that policy is the unforgivable sin. They have fallen.

It is obvious, then, that the friction between the minor and central authorities of London has an important bearing upon the whole principle of public ownership, because it illustrates that a duplication of authorities means a conflict of municipal ambitions. The borough councils may be deemed a useful stumbling-block to the designs of the authorities at Spring Gardens; but their attitude is only that of Satan rebuking sin. They are themselves deeply involved in trading operations. Extravagance in this and other directions is their watchword. Their debt increases continuously, and it now amounts to many millions sterling.

This expansion of the financial burden cannot be explained away by growth of population; nor by any development of new industries, and the consequent increased wants of the locality which would arise therefrom. For the present tendency is the decline of London as an industrial centre.

The redemption of the sums borrowed is made a charge on the future. While the next generation of taxpayers will have to bear the sins of the present administration, the taxpayer of to-day is groaning under the burden of meeting indebtedness made in the past. Hence sums in respect of repayment of, or interest on, loans is a permanent charge on the taxes. Indeed, one Battersea taxpayer states that of the dis- 
trict's whole income (about $£ 400,000$ ) more than a quarter is being paid away on account of loans, raised either by the Municipal Council or by the other spending bodies (the Board of Guardians and the London County Council), whose rates it collects. In other words, the moneylender takes about $4 s .8 d$. out of every $£$ I collected from the taxpayer.

As an example of the tax demand note presented by local authorities to a British householder, let us examine the bill tendered to a Battersea taxpayer. It contains demands from the Board of Guardians for the administration of the poor law, demands from the London County Council for general administrative purposes and for education, the police tax, and the borough councils' own taxes for local administration. The following table shows the proportion these spending bodies take of the $8 s$. $4 \frac{1}{2} d$. (or $4 \mathrm{I} \frac{1}{2}$ per cent. assessed on his rent) which is extracted from the Battersea taxpayer :

Board of Guardians for s. $d$.

the poor ... . I II 1 in the $£$ or nearly $10 \%$ of the rent. London County Council I 6

London County Council

for education

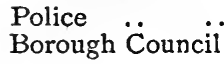

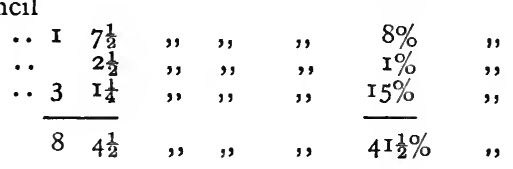

If, therefore, a Battersea householder's rent is $£^{20}$ a year, he pays $£ 2$ toward keeping the poor of his district, $£^{\mathrm{I}}$ Ios. to the London County Council, $£^{\mathrm{I}}$ I2s. for educational purposes, 8 s. to the police, and $£ 3$ for 


\section{I48 THE DANGERS OF MUNICIPAL TRADING}

local purposes, or altogether $4 \mathrm{I}^{\frac{1}{2}}$ per cent. in general taxes, in addition to his rent. This, it may be pointed out, is distinct from the income-tax levied by the State for national purposes, which takes about another shilling out of every sovereign of his earnings over $£$ I6o a year.

These rates would appear to be much higher if the assessment value of the property, on which they are raised, was not tinkered with and increased, by which method a great deal of money is obtained without raising the tax rate per pound. In fact, it is estimated that but for the increased assessment device Battersea taxes would be quite I3s. in the pound, or 65 per cent. on the rental value of property. This tinkering with assessments had an inductive influence on the waterrates, and it led automatically to high prices, thus hastening the compulsory purchase of the water companies of the Metropolis, and enhancing the price of the concern. As a further illustration, taking London as a whole, the assessment value of the Metropolis has risen from over $£ 34,000,000$ in I895 to over $£ 49,000,000$ in I904, or an increase in nine years of about 20 per cent. in the rental valuation of property on which local taxes are raised. Put differently, a penny rate which in I895 realized $3 s$. $4 d$. on a house of a rental of $£ 40$, in I904 brought in $4 \mathrm{~s}$. Battersea's own local rates admit of a similar analysis, showing that it is spending to a much greater extent than its actual rate of taxation indicates.

Poplar is another district where the incidence of 
taxation is heavy. It amounts, in fact, to no less than 60 per cent. on the rental value of property, or I2s. in the pound. In this district, where one person out of every fourteen is a pauper living on the taxes, the burden is heaviest on the trading community, the case for which has been well presented by Mr J. G. Broodbank; of the London and India Docks Company, in a letter to the Tribune. 'We make about $£$ Ioo,00o a year profit at Poplar', he says, ' and out of that we have to pay $£ 30,000$ in taxes. We get nothing for the money. We have to make our own roads, do our own sewering, and provide our own police. We do not use the baths nor the board schools. A third of our local profits go in taxes, and we have not a vote in return for it. Why, even the Sultans of the East do not impose such taxes!' The proportion of taxes to the net profit of this company in Poplar works out at about 2I per cent. The profits of other companies established in the same district are lightened by taxation as follows: South Eastern Railway, 20 per cent. of the profit; Great Eastern Railway, I7 per cent. ; South Western Railway, I5 per cent. ; London and North Western Railway, II per cent. ; and the Great Northern Railway, Io per cent. of the profit.

The scandal of the taxes in districts like Battersea and Poplar, not to mention West Ham, where the party which benefits by the rates is stronger than the party which pays them, has had the effect of driving manufacturers and traders from them; it is true that other works have started in West Ham, but the prosperity 


\section{I50 THE DANGERS OF MUNICIPAL TRADING}

of industries upon which the working population depends is in danger of becoming undermined. In fact, as the Times has pointed out, that position has already been reached. 'What with the increase in the rates', it remarks, 'and what, in effect, is the same-the increased value at which property is assessed-London is not, for their purpose, what it was. The manufacturers, shipping, and dock companies begin to find that the more they are able to carry their works and operations outside the metropolitan area the better for them. London firms nowadays, when contemplating removing their business or extending their operation into another neighbourhood, first inquire what the rates are. To such an extent does the incidence of rates enter into the calculations of those who meditate the extension of industrial works that a fundamental rule of business has now been evolved for all who are acquiring land and buildings-Keep outside the jurisdiction of an extravagant municipality.'

Major Leonard Darwin ${ }^{1}$ calls attention to the serious danger indicated here: 'If in any town Municipal Trading has been largely undertaken, and if for any cause the population begins to decline before the debts thus incurred have been redeemed to any material extent, the result must be a reduction of Municipal profits and increase in local taxation. And the serious aspect of the case is that, in these circumstances, taxation is likely to go on increasing at a geometrical ratio; for the desire of the inhabitants to leave the neighbour-

1 Municipal Trade, p. 442. 
hood will increase with every increase of taxation ; and the burden of taxation will increase with every new departure of inhabitants. There is in these circumstances every condition necessary to produce commercial disaster and municipal bankruptcy.'

As far as the London borough councils are concerned, this fate, toward which many of them were undoubtedly leading their districts by the increment of liabilities they created each year, has been peremptorily checked. The elections in November, I906, resulted in a clean sweep of the Progressives (the ownership party), and a remarkable accession of strength to the Moderates. There are some boroughs, once Progressive, in which hardly any members of that party have survived, and in which there is now only one party, the Moderates. All along the line the anti-ownership party were at the top and the Progressives at the bottom, though, indeed, the Labour candidates were sometimes lowest of all. In I903 there were fifteen boroughs in London in which the Progressives were in a majority; there are now two. The 26 boroughs that the Moderates have thus won are in all parts of London-in the north, at Islington and St. Pancras ; in the south, at Camberwell ; in the east, at Poplar, Stepney, and Woolwich; and in the west, at Fulham. The general totals show 959 Municipal Reformers (or anti-ownership party), 272 Progressives (the defeated Socialists), 34 Labour, and 97 Independent members. In the provincial towns there were also victories for the supporters of private enterprise, though the ownership defeat was less crushing 
than in London. But in Glasgow in thirteen contests 9 Labour candidates were hopelessly beaten, I Labour magistrate lost his seat, and only 3 Labour men out of 34 candidates who went to the polls were returned.

It is unfortunate, as the Times has pointed out, that many of the most objectionable of the municipal undertakings which have now been practically condemned by the public are to some extent of the nature of commitments, and that their immediate abandonment may not be altogether practicable. But at last the continuance of the Progressive policy has been interrupted by the more prudent element which has now entered the London borough councils. 


\section{CHAPTER X}

SOLVENCY OF CITIES

7 HE inflation of assessments for taxation purposes 1 shown in the last chapter only means that in time British municipalities will be raising money on a wholly fictitious security in the exercise of their spending powers. The question arises as to how far their credit can stand the strain. Much stress, the London Municipal Notes says, is laid by the supporters of Municipal Trading on the soundness of municipal credit. Let us go to the root of the matter, and ask, with that journal, What is credit generally? To quote William Cobbett, credit is a thing wholly dependent on opinion. 'The word itself, indeed', says this old economist, ' has the same meaning as the word "belief." As long as a man believes in the riches of an individual, or any company, so long he or they possess all the advantages of riches. But when once suspicion is excited, the credit is shaken. So long as the belief is implicit, the person toward whom it exists goes on not only with all the appearances, but with all the advantages, of wealth, though at the same time he be insolvent. But if his wealth is not solid, if he merely have the appearance of wealth, if he be in- 


\section{I54 THE DANGERS OF MUNICIPAL TRADING}

solvent, he is liable at any moment to have his insolvency exposed.' It is urged in the case of London that its debt is fully secured on its taxable value. That debt is already well over double the taxable value, which has grown enormously in recent years. The London Municipal Notes, in directing public attention to the limit of a municipality's credit, recalls that assessment committees in fixing rateable value have not always held the scales of justice evenly. They have often been guided in their duty not so much by the real value of the property assessed as by the needs of the local authorities to obtain money. House property in many parts of London is becoming less and less profitable. The percentage of empty houses grows more and more. Nevertheless, the rateable value is raised.

There is thus created an appearance of wealth which does not really exist. If the exodus of Londoners continues, the example of West Ham will be repeated on a large scale, and with far graver results. The commercial decay, the driving away of the middle classes from West Ham, by reason of excessive rates, has been serious enough. The effect of such a state of things on the welfare of London is almost unimaginable. The wealth of London and 'the ability of it to pay' are phrases glibly used by Progressive apologists for rising rates. In using them it is plain they do not think who or what are the payers. They are poor. Not less than 44 per cent. of the assessed houses and tenements in London do not exceed $£ 20$ rateable value. That 44 per cent. represents the dwellings of the poor and very poor, 
who have a hard struggle to live. Though they may not pay rates direct, they pay them indirectly. The landlord pays the rates and adds them to the rent. In his work on The Life and Labour of the People of London Charles Booth points out that the population of London consists of :

\begin{tabular}{|c|c|}
\hline & Per Cen \\
\hline & .. 30 \\
\hline lasses in regular employment & $5 \mathrm{I}$ \\
\hline Idle, middle, and upper classes & \\
\hline
\end{tabular}

From this division it will be seen that 80 per cent. of the population of London belongs to the class which feels acutely excessive taxation. I am indebted to the journal named for this convincing view of the insecurity of municipal credit in London, which equally applies to other cities.

But the glamour of figures, the solid, persuasive security of the taxes indicated by an inflated valuation of assessments stated in terms of millions of pounds sterling, wins over the investor who goes into the market. British cities, he reflects, do not default, however bad their administration, so that his money is all right. But for the trust of the investor in the municipalities, his money would go in sound commercial enterprises, built on foundations of substantial actual assets. For instance, the London County Council, after giving the market a rest to enable investors to recover from the drain on their resources occasioned by previous municipal loans, has only to make an issue for a large amount, which has every chance of being subscribed-and over- 


\section{I56 THE DANGERS OF MUNICIPAL TRADING}

subscribed-for within a very short time. But, like a speculative syndicate, conscious of the defects of the proposition it submits to the public, it may thus succeed by the bait of an enticing discount which, indeed, municipalities are now generally compelled to offer to induce a sufficient response. The London County Council has an annual expenditure within $£ \mathrm{I}, 000,000$ of the annual expenditure of Belgium, exceeding that of Saxony, the Argentine Republic, Norway and Sweden combined, the Netherlands and Portugal, double that of Roumania, and more than four times that of Denmark. The Council may sink most of the money it raises in street railways whose accounts can only be made to show a profit by not debiting the large expenditures made in respect of them, or in more boats whose running shows an enormous loss. The investing public, however, are not sensible of the doubtful uses to which London's chief municipality applies the money. They are only concerned with the security offered-the assessment value of the Metropolis-i.e., the ability of the taxpayer to pay, whatever befalls. But conceive of the reception which a municipality's issue of a loan for speculative trading purposes would receive in the money market if, as security for the loan, it relied solely on the assets of the particular undertaking in respect of which the money was wanted? The losses resulting from the municipal management of electricity works all over the country are a by-word. Hardly one, indeed, if proper allowance were made for depreciation and sinking fund, would show a profit. It is safe to say that 
such municipal undertakings would receive scant recognition as payable propositions in the market on their own merits. What chance, for that matter, has a private electrical undertaking of raising money, with a bad balance-sheet, not for one year, but from the start? Municipalities are well aware that, but for the substantial assets of the taxes, they could not raise money for their trading speculations at all. Their undertakings, therefore, cannot stand on their own foundations; their own assets are negligible for the purpose of raising money on them ; and without the aid of the taxes they would fall to pieces. It hardly needs saying that this dependence on the taxpayer as an asset for loan purposes, and not on the undertaking itself (which, as shown, would cut a sorry figure as such), constitutes the cardinal weakness of the principle of conducting commercial businesses out of public money.

The question of raising municipal stock was recently raised in the Tribune, apropos of a strong attack made by $\mathrm{Mr}$ G. R. Sims upon the extravagance of local authorities. By way of rejoinder Mr George Bernard Shaw wrote asking Mr Sims to obtain for him some municipal stock at panic prices, as he was seeking cheap gilt-edged investments. 'A brief search will show', states this reckless speculator, "that the very people who have been stuffing him' (Mr Sims) ' with all this nonsense about municipal bankruptcy will lend money to a municipal corporation on terms that they would not entertain for a moment from a private company. The London County Council is at present in financial despair 
because the actual scarcity of money, caused by the burning up of hundreds of millions of pounds in South Africa, Manchuria, Russia, and other seats of war, prevents it from raising capital at 3 per cent. The County Council has to pay extra for scarcity, as everyone else has, but will anyone be so hardy as to pretend that it has now, or ever has had, to pay a farthing for risk? And yet if a private company had been financially written down by the Moderate press and the anti-Prograssive alliances and leagues and Ratepayers' Associations for twenty years, as the Council has, it would not be able to raise a shilling at 50 per cent.'

A correspondent was quick to remind Mr Shaw that he would probably have a chance one day of obtaining London County Council securities at panic prices. As he points out, they dropped a good many points long after the wars he names, and it is because investors are beginning to doubt the security. 'A 3 per cent. giltedged investment, secured on the rates of the premier city of the world, being ro $\frac{1}{2}$ points below par, shows what investors think of present municipal undertakings.' Another correspondent commented that municipal stocks are procurable at other than famine prices, not because municipalities make profit, but because they do not depend on profits to pay interest or repay capital, but upon the rates. It is the power of the 'screw' which makes these investments gilt-edged. But neither has hit upon the real cause for the depreciation of municipal stocks. There are far too many of them issued. Municipalities have flooded the market 
with their loans, whereby the investing public has been drained of its surplus capital. This outcome, however, hits both ways. Whilst stagnating private enterprise by withdrawing from it capital which, but for its absorption by the municipalities, would be attracted to it -a dearth of money has also the effect of prejudicing the success of further new issues of the municipalities. When there are few or no issues of new municipal stock, therefore, little money is available.

In one way it would be advantageous to the taxpayers if this state of things continued. Not to be beaten, however, the municipalities in their desperate straits fall back on issuing and renewing bills. In this direction, as in their too great dependence on the resources of the money market for raising bonds, they have overreached themselves by issuing too many bills, with the result that on the expiry of a bill they increase the rate of discount in order to ensure its renewal. Only recently Birmingham municipality had to pay an average percentage of nearly $£ 3$ IIs. $5 d$. for the renewal of the current issue of $£ 300,000$ bills for twelve months. A year previously the same bills were allotted at the rate of $£^{2}$ I4s. $4 \frac{1}{2} d$. per cent. A distinguished English lawyer, who is well acquainted with the strange ways of municipal finance, thus writes to me apropos of this very high rate of discount of first-class paper: "What possible chance has a merchant of being adventurous if he is to come into competition with municipalities who are denuding the local banks all over the country of their floating balances by offering acceptances at 
this price? When evidence was being given on the Local Loans Committee in I902, some of the town clerks defended the system of raising money by bills, saying that the bills were of such large amounts that they did not come into competition with mercantile bills. This is an entire fallacy. I am assured by money brokers that the larger the amount the better they like the bill, as it is taken up as a floater all the more readily the bigger it is. Currency questions are so difficult that one hesitates to dogmatize upon them; but I have the strongest impression myself that these municipal bills are subversive of those laws which are so inexorable in their vindication of sound economic principles. The mercantile bill is an instrument of barter which is accepted by commercial people in lieu of cash, and so economizes the currency of the country. These municipal bills are nothing of the kind. There is no transference of value which, as in the case of the mercantile bill, is certain to put the drawer in funds by the end of the currency of the bill; on the contrary, when the bill runs out, the treasury of the municipalities is not refunded, and they have no recourse except to renew the bill, and thus to perpetuate their depletion of available currency. In fact, the bill is not used for floating over a temporary occasion, but is renewed to put off the meeting of a perpetual liability. If this is sound reasoning, the issue of these bills has exactly the same injurious effect upon the community as a depreciation of the coinage would have. It may be said that these bills do not pretend to follow the analogy of mercantile 
bills, but are modelled upon Government Treasury bills. My answer to this is that the municipalities do not budget their expenditure. The Treasury bill is issued to bridge over the gap between expenditure and receipt in the annual revenue of the Government; the municipal bills are not issued on revenue, but on capital account, and are just as improper a method of finance for them as they would be for a railway company to employ for the financing, for instance, of their capital outlay upon a permanent work.'

We have, then, to contemplate a depreciation, not of coinage, but of credit. And just as the tendency of a depreciation of coinage is to degrade the quality of commodities, and to transport all good coin, so depreciation of credit leads to sophistication of every kind, and it involves ultimately the transfer of British credit to foreign countries.

Another device of the municipalities to raise money is to tout among the humbler class of their thrifty citizens to induce them to deposit their savings with them. In this direction they attempt to tap an investing public which knows nothing about the money markets, and whose knowledge of finance is confined to the interest they obtain from their bank. In the money market they rob private enterprise of the cream of would-be investors ; in their own district they actively compete with the ordinary banks for deposits by offering a higher interest. Glasgow, Edinburgh, Manchester, and Liverpool advertize for deposits from time to time, as well as county councils and even parish councils. 
A correspondent in the Daily Telegraph (October 27, I906) makes the following interesting remarks about the system of finance practised by Edinburgh municipality, which has a resemblance at least to municipal banking : 'They advertize for loans and take money on deposit from whoever offers it, for long or short periods-probably, unless in very exceptional circumstances, for not less than a month. They give in the way of interest $\frac{1}{2}$ per cent. more than the bank rate, whatever that may be. The exact percentage of interest is not stated in the advertisement asking for money, and it varies according to the bank rate. This $\frac{1}{2}$ per cent. more than the bank induces lawyers especially to invest temporarily their clients' money with the corporation rather than with the banks. At any stated date the chamberlain of the city, who is the official charged with its monetary concerns, will have average deposits on hand of about threequarters of a million sterling, but the annual turnover is, of course, much greater than that sum. There is not at present the same flow of money from small depositors as there was a year or two ago. This is in a part accounted for by the fact that many safe investments, such as Consols and railway stocks, have been low in price, and the money has gone into them. Money that formerly flowed freely into the coffers of the municipality has had to be sought on loan from quarters where it was known money could be had. The system works exceedingly well from the municipal point of view, but it has all along been a thorn in the side of the banks, who have once or twice tried to retaliate on the muni- 
cipalities, without, it may be observed, any very permanent results. It has been roughly estimated that in I905 something like six or seven millions less of business was done by the Scotch banks than formerly on account of the municipalities, school boards, parish councils, county councils, and other public boards taking loans directly from the public, instead of dealing, as formerly, with the banks.'

The same journal mentions that something like municipal banking has been started at King's Lynn-a municipality which is credited with being the pioneer in raising loans for municipal purposes. That borough recently announced that it would receive amounts of $f_{50}$ and upwards at $3 \frac{1}{2}$ per cent. interest, repayable at six months' notice, or at a shorter term by arrangement, to meet an outlay on its electric-light undertaking. In ten days all the money required was received. The county borough of Devonport is another instance of this form of municipal enterprise. A circular published in June, I904, announced that the municipality was prepared to receive sums of $£_{\text {Io }}$ and upwards on deposit, repayable at one calendar month's notice at any time, bearing interest at 3 per cent. per annum. "These sums', the circular stated, 'are free of all charge or expense to the depositor, and can be increased from time to time by the addition of further sums of not less than $£ 5$ o.' It added that ' any number of deposits may be made by one person, and no limit in amount is placed upon any one account', and, as apparently indicating that these deposits are not limited to the people of 


\section{I64 THE DANGERS OF MUNICIPAL TRADING}

Devonport, it intimated that 'investors may send their deposits by cheques, postal orders, or other means.'

The expedient, however, has hardly proved successful in every case. One cautious borough (Bury, Lancashire), before raising money by this means, sought the experience of other municipalities. Nineteen boroughs, it seems, invited loans from $£$ Io to $£ 90$, but met with a very poor response. In some cases they failed altogether. Of the boroughs which raised a considerable amount, the most noticeable case was Bolton, which succeeded in obtaining $£ 30,000$ in small loans, varying from 3 to $3 \frac{1}{4}$ per cent. interest. The Birmingham municipality, a few years ago, raised $£$ I59,I90 in various sums, accepting as small an amount as $£ 20$; but it found the transaction costly, and abandoned the scheme. The borough treasurer of Bury reported against the receiving of small deposits.

The whole practice is, of course, an encroachment on the savings of the people, which, as has been pointed out by the Statist, are, even in the richest countries, limited in extent. Those savings have to keep up all existing businesses, and to supply the means of extending those businesses and founding new industries. To the extent to which municipalities make demands upon the savings of the country, they lessen the fund that is available for business. If anything were to happen which would lead depositors to call in their money, the local authorities might find themselves in a very serious position. It is said, for example, that the floating debt of the Glasgow Corporation amounts to three millions sterling. If 
political anxieties or other causes were to lead depositors to call in their loans, how, asks the Statist, would the municipalities provide the funds to make repayment? It might be impossible to borrow on the open market, and it would be a serious thing to expect bankers to supply them with the means. The municipalities take money at a comparatively high rate of interest for three, five, or seven years, and they also issue notes for six months or twelve months; whilst several of them have been likewise borrowing from savings banks. In all these ways they are laying themselves open to a run which would assuredly place them in an unpleasant predicament, for they have no securities-no liquid assets.

With the market losing faith in them, forcing them to angle after the savings of their own people, which are promptly sunk in unsound undertakings that compete with local concerns whose surplus earnings provide the capital, how are municipalities going to justify themselves? What will be the fate of communities whose whole existence will then depend on their municipal councils, as they spread out their trading ramifications like a net, holding in financial serfdom rich and poor alike? 'What', asks a writer in the Tribune, ' is to become of private property itself? What is going to take the place of the public healthfulness derived from competition, when only an omnibus-jack-ofall-trades-municipality rules prices and markets ? The picture of everything for everybody is a glowing one, but it suffers from an incurable disease : it won't work 


\section{I66 THE DANGERS OF MUNICIPAL TRADING}

in practice. No elector, with ever so good an intention, can know his municipal rulers intimately enough to determine that they are capable of controlling a variety of industries of which they have no expert knowledge. Who, then, is to save us from the amateur, the muddler, the self-seeker, the office-seeker, the officecreator, from irresponsible extravagance, and from corruption in a hundred forms? May Heaven spare us from an officialdom which, not content with watering our roads, must needs aspire to wash our clothes and comb our hair.' It is not pleasant to contemplate a muddling financier in charge of the municipal savings bank.

But the really disastrous stage in English municipal methods is yet to come. At present the whole ownership policy, as now recklessly pursued, has become a burden with which most people have grown irritated and impatient, and the position to-day is full of warnings to other countries whose inhabitants take the trouble to inquire closely into the question; but the actual crisis toward which all this insane public borrowing is tending may be deferred for some years yet, so great is the reserve strength of Britain's finance and trade. 


\section{CHAPTER XI}

\section{DELUSIVE DEMONSTRATIONS OF PROFITS}

T $T$ is not a far cry from fictitious assessment values 1 (which beguile investors in municipal stocks into the belief that they have sound security for their money) to fictitious profits alleged to be made out of the undertakings in which the investors' money is spent, in their turn flaunted before the taxpayer to persuade him that it is affording him relief in taxation. But as neither a reduction in assessment value nor in the tax levy simultaneously occurs with the ascertaining of these 'profits', a taxpayer has some excuse for doubting whether they yield any benefit to him at all. It is poor consolation for him to be told that but for these 'profits' his tax bill would be higher; it rather leads him to the conclusion that if the municipal 'reproductive' undertaking had no existence, he would not be a penny the worse, since, with its existence, he is not a penny the better. This is the point of view of the plain man. But his taxes would really be decreased if the undertaking had no existence. Ignorant as he is likely to be of the strange ways of municipal accountancy, it does not dawn on him that the annual municipal balancesheet of the particular undertaking is prepared for his 


\section{I68 THE DANGERS OF MUNICIPAL TRADING}

special behoof, and could easily be pulled to shreds and tatters by the rawest student of a school of accountancy. Let it be assumed that in a given year a municipal ' reproductive' undertaking had an actual revenue of $£ 25,000$, an actual expenditure inclusive of payment of prior charges for interest on capital, etc., of $£ 35,000$, and yet showed a 'profit' of $£ 5,000$. It is, of course, a loss of $£$ ro,00o. But by debiting $£ I 5,000$ to the general municipal account, thereby reducing the expenditure of the undertaking as set out in the balance-sheet to that amount, or in other ways keeping out of the balance-sheet items actually incurred which should appear on the debit side of the account, the undertaking is made to show a profit of $£ 5,000$, placed ' in relief of taxes.' It is the hidden presence of the $£$ I5,000 as a debit item in the general municipal account, probably spread over a number of entries, which is really spent in respect of the undertaking but not charged to it, that prevents the tax levy from being reduced. If the undertaking did not exist, there would be no occasion for resorting to such a device on the part of a municipality anxious to give an account of its stewardship, and the amount necessary for taxation would be proportionately reduced.

The example is a broad one, but the principle of it is commonly practised to a more or less degree by many British municipalities, and in casting about for illustrations, the difficulty would be to limit their number. The method has been compared to the success of the child who made a good profit out of poultry when his 


\section{DELUSIVE DEMONSTRATIONS OF PROFITS I69}

parents provided the food and the upkeep and paid for the eggs. In a general way the example of the child's poultry farm applies to municipal undertakings, as their results are made to appear in the profit and loss accounts.

That profits in gas, water, and street railways are made by municipalities there is no doubt, but when such results are invidiously compared with private operation, the municipalities can only hope to show that public operation is 'superior' by first submitting the expenditure side of the undertakings to a process of attenuation before final publication of the accounts. There could be no stronger evidence than this that they themselves are secretly conscious of their unfitness to handle the particular utility, especially when it is borne in mind that they enjoy a monopoly, and being thus exempt from competition, their revenue rolls in without their being compelled to spend a penny of it in respect of outlays which two competitive companies would be driven to undergo in order to checkmate one another. They are on safer ground when they abandon altogether the quest for 'profits '-whether they are really to be made, or only to be concocted in the balance-sheets. Generally, however, they are dominated by what Mr. Bernard Shaw ${ }^{1}$ calls 'the commercial view.' As this candid friend of the municipalities puts it, 'they often encourage themselves rather childishly, keeping their accounts in such a way as to produce the utmost possible appearance of commercial prosperity by throwing as much as possible of the expenses on the general rate

1 The Common-Sense of Municipal Trading, chapter xi. 
whilst crediting the receipts of each municipal service to its special department.' 'When a municipal electriclight undertaking shows a profit, which is handed over to the relief of the taxes, is a taxpayer, who is also a consumer of electricity, gratified by the intelligence ?' asks Mr Shaw. ' 'Not at all', he answers; 'he indignantly demands what the municipality means by overcharging him for current in order to relieve the rates of his neighbours who burn gas or oil. And his protest is perfectly justified. The object of Municipal Trading is not relief of rates : if it were, it might be manipulated so as to throw the entire burden of local taxation on certain classes of consumers exactly as the entire burden of local taxation in Monaco is thrown on the gamblers of Monte Carlo.'

No phase of the municipal ownership question has provoked more controversy than this question of profits. In the United States the profit argument is put forward very strongly by municipal Socialists-in fact, it is their strongest card. The American tramways, gas, electric-lighting, and telephone service is uniformly up to date, and the companies, as a rule, seem ready to meet public requirements. The only valid excuse for a change in policy is that private companies are making out of public services too much profit and cities too little. Much of the confusion on this subject of profit comes from the lack of a clear definition of the word itself. In its business sense the word 'profit' means what is left in a commercial operation after payment of

1 The Common-Sense of Municipal Trading, chapter xi. 
rent, labour, raw material, interest on borrowed capital, taxes, insurance, remuneration for superintendence, provision for wasting assets, and indemnity for risk. No municipal trader has ever undertaken to deal with this question of profits on its merits, and with this definition before him. The more advanced and enthusiastic seek to evade the issue by declaring that there should be no profits, that industrial undertakings should be carried on at the expense of those who pay the taxes for the joint benefit of those who do and those who do not pay taxes. This simplifies matters for all but the very considerable body of ratepayers who do not use the particular service; and this is what Municipal Trading may come to. Another class of municipal traders content themselves with hopelessly mixing up 'profits' derived from trade as above defined and 'profits' derived from the grant of rights or monopolies. It is only by this deliberate confusion of terms that they can hope to show that the ratepayers must be better off if they work these undertakings themselves than if they leave them to companies, as is done in the United States. I have never seen this important difference more clearly stated than by Mr Arthur Chamberlain, of Birmingham, in a letter he wrote once to the taxpayers of that city, in which he said: ' I understand the argument that whatever profit there is the ratepayers should have-and I agree; but I distinguish between the profit that is due to the grant of a monopoly and that which attaches to the employment of capital and its management. The one should be a certainty; the 


\section{I72 THE DANGERS OF MUNICIPAL TRADING}

other must always be a speculation. Now, I say, let the ratepayers take the certainty and leave the speculation to the speculators.' No less plainly has the position been put by Mr J. A. R. Marriott ${ }^{1}$ :

To secure high profits-except, of course, from monopolies-you must, as a rule, take large risks. If the element of risk be absent or slight, competition will quite certainly come in and automatically reduce the profit to a minimum. But if the element of risk be present, in however small a degree, corporations, standing in a fiduciary relation to the ratepayers, have no right to embark upon the business. But nakedly and broadly it comes to this : all trading must be, in a greater or less degree, speculative; and local authorities, by general admission, have no business to speculate. From whence do they derive the wherewithal to speculate? Either directly from the rates, or else from loans borrowed upon the security of the rates. In either case, it is the ratepayer, involved with or without his own consent in a speculative concern, who has to bear any loss which may be incurred.

So far United States citizens have preferred the certainty of the meat in their mouths to the attractive reflection in the stream. This finds expression in the contracts of New York and Boston for building and working the new subways, which were let to private companies under control of the municipalities, and to a more or less extent in all recent legislation relating to the use of streets and taxation of franchises. It has always been found possible, by increasing the rates of State and municipal taxation of these franchises, to secure a more equitable share of profits from monopolies without saddling the risk upon the taxpayers.

1 Fortnightly Review, December, 1902. 


\section{DELUSIVE DEMONSTRATIONS OF PROFITS I73}

In Dublin, for instance, there is an electrical system of street-railways, extending to close on fifty miles of track, which contributes $£$ I5,000 a year to the municipal treasury by way of rent paid by the company operating it. This forms a regular annual revenue which, were the lines municipally managed, would conceivably be maintained at the same level if higher working cost had not become recognized as a first principle of municipal conduct of public services ; and, as has been shown, the effect of this disability is usually made to appear less by not debiting to the undertaking various outlays made in respect of it. A case in point is Liverpool. At the end of last year the local debt had been increased by over $£ \mathrm{I}, 000,000$ for street widenings made on account of the municipal tramways, but when it was proposed to charge the tramway undertaking with a moiety of the expense, the motion was defeated. Had this business-like policy been adopted, instead of the whole cost being thrown on the general municipal account-i.e., the taxes-the Municipal Trading Party would naturally be deprived of the opportunity of boasting that profits had been made and applied in relief of the taxes, or else the profits would be very small indeed. Another municipality boasted of large street-railway profits. Steps were taken to examine the accounts, and it was found that $£ 300,000$ had been charged to the Public Works Committee of this municipality for street widening, necessitated entirely by the installation of street railways.

This method illustrates the financial side of street 
widenings for the purpose of tramway extensions, when, in the one case, they are undertaken by the local authority, and when, in the other, undertaken by a private company, which would be called upon to make the widening as a condition to their extending their lines. We may pass by discussing the right of the local authority to jump at the chance of getting a road widened at the expense of a private company which desires to extend its lines, ${ }^{1}$ when it is strictly more of a municipal duty than their trading practices. It is, however, a duty which sometimes the local authority cannot avoid performing where their own tramway extensions are concerned; but of the cost incurred in such a street widening, made wholly on account of the municipal tramway extension, the general practice is to debit only a third of the capital expenditure of the scheme, and the other two-thirds come out of the taxes.

The London County Council, however, have gone much farther than this. Their tramway extensions necessitated extensive street improvements, costing some millions sterling, only a tithe of the sum spent on which has been allowed to appear in the tramway's account, the other nine-tenths falling on the taxes. This easy method of relieving the capital expenditure of a municipal undertaking became revealed by the

1 The London United Tramways Company have spent, according to the evidence of Sir J. Clifton Robinson before the Royal Commission on London Traffic, a sum of $\ell_{1}, 000,000$ in respect of road improvements and way leaves in connection with their extensions. 
publication of a report wrung from the Council by the Moderate party in order that some light might be thrown upon the remarkable absence from the tramway's account of considerable capital expenditure made solely on account of the tramways. It was ascertained to be no less than $£ 4,044,844$, of which only $£ 377,260$ was debited to the tramway undertaking. The people of London were saddled with the rest. A member of the Council (Captain Swinton), on whose motion the report had been made, accused the Council of misleading the taxpayers into the belief that the tramways paid one-third of the cost of street widenings. As reported ${ }^{1}$, his remarks at the Council meeting at which the report came up for discussion illuminate the deceiving tactics of the municipalities, whereby their trading undertakings acquire a meretricious appearance of soundness. He showed that, included in the sum of $£ 4,044,844$ were three items amounting to $£^{1,106,354}$, of which only $£^{621}$ was charged against the tramways. After allowing for a sum of $£ \mathrm{I}, 007,354$, the expenditure of which might be justified for necessary improvements of the general traffic, there remained $£ 3,000,000$, of which there was no evidence to show that any portion would have been spent except for tramway purposes, and yet only one-eighth of it appeared in the tramway's account.

But this was not all. The inflation of tramway profits is further helped by charging a wholly inadequate sum for the services of the Council's central staff. Captain

1 Morning Post, October 17, 1906. 


\section{I76 THE DANGERS OF MUNICIPAL TRADING}

Swinton showed that since the Council entered into the tramway business, "the cost of the central office

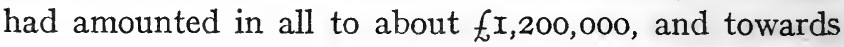
this there had been paid, in respect of the work of the tramways, the ridiculous sum of $£ 8,160$ on revenue account. Until last July there was no charge at all made against the tramways in respect of the clerks' department. The parliamentary branch naturally did a great deal of work for the tramways, and yet nothing was charged in respect of that. Business men would probably tell them that the tramway enterprise of the Council owed London a million of money. At least, so far from having made a profit, it owed London half a million.'

To this searching criticism the Progressives responded by the old accusation that the Moderates desired to destroy the municipal tramways. So far from that being true, the Moderates only required that all proper charges should be debited to the tramways undertaking, and that its development should be conducted on business lines to enable them to know exactly what it cost.

A private company has no such devices at hand by means of which it can elude the debiting of capital expenditure incurred in relation to its business. On being forced to undertake a street widening it must naturally place the whole of its cost to capital account. Nor can office and clerical expenses be omitted from, or only partially appear in, its revenue account. Hence we have, on a comparison of municipal and private tramway profits, important capital and revenue items 
only partly shown in the municipal and fully shown in company accounts; but, strange as it may seem, this inequality in the apportionment of the capital and revenue expenditure in respect of tramway extensions does not turn the scale in favour of municipal profits.

The superiority of private operation on the 'profit' argument has already been shown by the history of the Northern lines before they passed into the control of the London County Council ${ }^{1}$. The Council now owns ninety-nine miles of tramways-namely, fifty-one miles on the Surrey side of the river, the Southern lines ; and forty-eight miles on the Middlesex side, the Northern lines, which latter, up to April of I906, was worked by the Metropolitan Tramway Company on a lease from the Council, now extinguished. From I894 up to March 3I, I906, the profits realized from both systems which were applied to the relief of taxation - the Southern, be it remembered, operated by the Council, and the Northern leased to and operated by a private company-amounted to $£ 293,592$. This is the record for twelve years in which the Council had been interested in tramways. The total earnings of the Southern and Northern system in that period totalled $£ 326,58 \mathrm{I}$, of which $£ 314,337$, or 96 per cent., was earned by private enterprise. Since I900 the Council has earned from the Southern system, which it operates itself, a sum of $£ 23,909$, while from the Northern system, worked by a company, the taxpayers have 1 Chapter viii. 
received no less than $£$ IgI,595. It is apparent, therefore, that had the County Council leased the Southern system also to a company, instead of working it themselves, London taxpayers would have gained something like $\mathcal{E}_{\mathrm{r} 68,000}$. Even the small profit the Council have obtained from the Southern lines has only been possible by setting aside a wholly inadequate sum for depreciation-only I'I per cent. as the capital cost. The Council's own expert has admitted that if $\mathrm{I} d$. per car mile for renewal, which had been allowed in previous years, had still been maintained, there would have been a loss of $£ 4,000$ instead of a profit of that figure for I905-06. As a matter of fact, the Council have only set aside for depreciation during the past four years an average per car mile of considerably less than a halfpenny a year.

The difference in the working of the two systems will be better shown by this table of profits for the past two financial years :

$\begin{array}{ccc}\text { Year. } & & \begin{array}{c}\text { Net Profits of Northern } \\ \text { lines leased to and } \\ \text { worked by a Company. }\end{array} \\ \text { I904-05 } & \ldots & \ldots £^{22,836} \\ 1905-06 & \ldots & \ldots \quad 27,575\end{array}$

Net Profits of Southern lines worked by Municipality.

$£ 7,054$ 2,3 I9

In the financial years I902-03 and I903-04 the Southern lines had deficits of $£ 2,250$ and $£ 8,200$ respectively, so that the fact that the London County Council had turned a deficit into a profit, though a diminishing one, may be counted for righteousness. But the public spokesman for the Council, in defending 


\section{DELUSIVE DEMONSTRATIONS OF PROFITS I79}

the tramway policy, find they are on such thin ice when the results of the Southern lines are mentioned that they evade discussing them altogether, and endeavour to make capital out of the whole sum, including the profits of the privately worked Northern lines, which the London tramway revenues have contributed in relief of taxes. But it has to be emphasized, as Engineering has pointed out, that these payments in aid of taxation, though derived from tramway revenues, come mostly, as I have above clearly shown, from the money paid to the Council by the lessees of the Northern tramways as an equivalent of rental for way leaves 'They were not earned by the County Council ', remarks this journal ; " they are not the results of the Council's municipal trading, but, on the contrary, ceased because, and when, the Council entered on municipal trading in tramways. So long as the tramways were leased the ratepayer got relief without pledging his credit for the success or failure of a speculative undertaking.' There is abundant ground for the assumption made here that, now the London County Council have obtained full possession of the profitable Northern lines, their value to the taxpayers will diminish to the level of the Southern lines under municipal working.

Much has been said about the successful Glasgow tramways, but the annual results of their working show nothing which could not have been achieved by a company. The sum contributed to taxes out of the total receipts in I905, amounting to $£ 764,79 \mathrm{I}$, was only 
$£ 25,000$. With that figure the Dublin company's annual contribution to the town fund of that city ( $£$ I5,000) out of receipts amounting to $£ 270,000$, or a third less than the Glasgow receipts, compares very well. The value of the Glasgow undertaking as a profitable concern is certainly not increasing, though the volume of the traffic is. This will be seen by the following table :

Year to May 3r.

$\begin{array}{ccccc}1901-02 & \ldots & \ldots & \ldots & 612,826 \\ 1902-03 & \ldots & \ldots & \ldots & 653,200 \\ 1903-04 & \ldots & \ldots & \ldots & 717,893 \\ 1904-05 & \ldots & \ldots & \ldots & 756,480\end{array}$

Average Receipts

Per Car-Mile.

d.

I I 66

I I.I9

IO. 58

IO. I 2

The steady decrease in the average receipts per car mile works out at more than $I_{2}^{1} d$. in four years. The average fare is $0.46 d$. per mile, and as this is practically the universal standard of tramway travel, Glasgow tramway fares are not cheaper than those of other towns. The municipality depends upon the 'profit' theory in relief of taxes, but it does not succeed in contributing more than $£ 25,000$ annually thereto, or, if it does, other items suffer by being insufficiently charged $^{1}$. Even if political considerations urge the Council to increase the tax relief, when one remembers that there is nothing exceptional about the fares and

1 In the financial year ending May 3I, 1906, the municipality improved on this sum by placing $£ 35$,000 out of the tramway revenue to the Common Good Fund. The elections took place in November. 


\section{DELUSIVE DEMONSTRATIONS OF PROFITS I8I}

stages in Glasgow, nothing in any way dissimilar from the conditions of company working, the contributions to the Common Good Fund are a poor reward for taking the permanent responsibility of this vast undertaking. If tax aid is wanted, a company would readily undertake to give $£ 40,000$ a year out of a gross revenue exceeding $£ 800,000$ which the Glasgow tramways yield. In fact, if I remember rightly, $£ 25,000$ a year has been offered the municipality by a company, and I am not so sure that it was not $£ 75,000$. An official of the old Glasgow tramways company takes the same view. Comparing the money drawings and the mileage of the present tramways with the old, and what the old company paid to the town fund on the same basis, $£$ roo,00o is under and not over the estimated sum that the Municipal Tramways Department should be paying. Any business man will agree that a monopoly of the streets of the city, such as the municipality possesses, would be worth a good deal more than $\ell_{100,000}$ per annum to any commercial concern. Glasgow and other chief cities of the United Kingdom represent municipal control of street railways at its best; but the level of efficiency they reach is equalled and exceeded, as the general public would amply testify, by two great street railway corporations-to name no others-the London United Tramway Company and the British Electric Traction Company.

It is a short step from municipal tramways to the electrical works which supply them with power; but it is difficult to consider them in connection with 
'profits' at all. However, as it has been ascertained that the principal municipal electricity works in the United Kingdom, with a capital sunk in them approximating $£ 28,000,000$, in 1905 realized a 'profit' of $\mathcal{E I}^{\mathrm{I}} \mathrm{I} 27,000$, the statement calls for inclusion under this head, even though it may not, like many street railway 'profits', bear investigation. The capital named represents $\mathrm{I} 84$ chief undertakings. Of the profits stated $(£ I, I 27,000) £ I, 000,000$ was produced by the first twenty concerns (the ten largest producing twothirds of the whole amount), and the remaining $£ 127,000$ has been credited to 164 undertakings with $£ I 5,000,000$ capital, this showing a return of less than I per cent. Of these, however, sixty-nine undertakings, representing $£ 3,000,000$ capital outlay, showed a net annual loss of $£ 70,000$. Let us take the other side of the picture. Sixty electrical companies in the United Kingdom, with a capital of $£ \mathrm{I} 7,000,000$, in I905 yielded a profit of $£ 2,000,000$, or $\operatorname{II}_{4}^{\frac{3}{4}}$ per cent. Here we find companies paying substantial dividends and placing adequate sums to depreciation and reserve in spite of municipalities having the great advantage of the load and revenue obtained from street lighting. Municipalities providing themselves with electric supply for street lighting from their own works have at hand one of the simplest means of making their electrical undertakings profitable, and where profits are shown, this mainly produces them. Further profits are created by their obtaining the energy required for their tramway services from their electricity works. Where the latter 


\section{DELUSIVE DEMONSTRATIONS OF PROFITS I83}

are profitable, therefore, it is in the main through the authorities being their own customers. But even when the revenue is thus certain and abundant, municipalities cannot avoid the vice of an acute company promoter : they endeavour to make the 'profit' look more. Added to the device, already illustrated, of not debiting to the expenditure side of the account all outlays made in respect to the undertaking, which effects this pleasing result, regard must be had to the equally important omission of items covering depreciation and renewal of plant, and an insufficient sinking fund.

The last-named defects of municipal management, whilst particularly conspicuous in the conduct of electrical undertakings, more or less characterize all municipal 'reproductive' concerns. It will be useful to consider, before leaving this question of municipal profits, what aspect they would show if proper recognition were given to the necessity of deducting out of profits and debiting to the undertaking sufficient sums to cover the yearly wear and tear of plant and adequate provision for redemption of capital. Here one leaves altogether the question of the ethics of the municipal control of businesses by the aid of public money. But if the ethical aspect could not be dismissed, two questions obtrude: (I) If municipal undertakings are really -as they are claimed to be-so many flourishing enterprises, then they justify the extension of local debt and high taxes; and (2) if they are otherwise, they show the unsoundness of the municipal finance revealed by 


\section{I84 THE DANGERS OF MUNICIPAL TRADING}

such enterprises, and its danger to the welfare of any country sanctioning them.

At March 3I, I902, £I2I,000,000 was invested in municipal ' reproductive' undertakings in the United

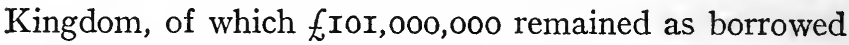
capital. These undertakings numbered I,060, and included waterworks, gasworks, electricity supply, tramways, markets, docks, and harbours, burialgrounds, baths and wash-houses, working-class dwellings, bridges, canals, cold stores, crematoriums, racecourses, estates, ferries, marine baths, concert-rooms, theatres, and golf links, not to mention oyster culture, rabbit-warrens, and pig-keeping.

To provide for paying off the sum of $£$ ror,000,000, the assets of which are represented by the plant, machinery, etc., of all these businesses, there was a sinking fund at the date named of only $£ 4,500,000^{1}$. To quote Mr J. Holt Schooling', ' a common argument in favour of the municipalities is that this debt is justified by the possession of the businesses created by the debt. But the validity of this plea must depend upon

1 A wholly illusory protection (apart from the inadequacy of the sums), because, by the municipalities' ingenious manœuvre of getting a provision inserted in their Parliamentary Bills authorizing the investment of their sinking funds in their own securities, the condition of the undertaking, when the forty or sixty years' loan for it has expired, will be worn or obsolete machinery, the permanent way a streak of rust, and the sinking fund which should be available for paying off the debt represented by the municipal-estate-probably unrealizable as an asset to the borrower demanding repayment of his money.

2 'Local Finance', Fortnightly Review, August, 1906. 
the results of the working of the various businesses. If these are being worked at no profit, but merely with an adequate yearly allowance for depreciation of plant, etc., and without any charge upon the taxes, then this plea may hold good from a financial point of view; assuming that the $£ \mathrm{I} 2 \mathrm{I}, 000,000$ have been judiciously spent-a rather large assumption. But if these businesses are being worked at a yearly loss, if there is no adequate allowance made for depreciation of plant, machinery, etc., if taxpayers have to make good a yearly deficiency on the actual working of these businesses, then this plea of justification for the debt upon these reproductive undertakings is wholly invalid, and the finance of them is absolutely unsound.' The following table, which has been prepared by Mr Schooling, shows the yearly average during the four years ended March $3 I$, I902, with regard to the working of all these reproductive undertakings :

Average yearly income $t^{1} 3,040,000$ Average yearly working expenses. . $£ 8,229,000$ Average yearly payment of interest, etc., on borrowed capital .. 4,240,000 Average yearly amount set aside for depreciation 193,000

Average yearly expenditure $12,662,000$ Average yearly net profit .. $£ 378,000$

This profit of $£ 378,000$ on a capital of $£$ I2I,000,000 works out at about $\frac{1}{3}$ per cent.-a small return which 
may suffice for a municipality, but would spell ruin to a private trader.' As showing, on the face of it, that there is no loss, such a profit may pass-if the amount set aside for depreciation ( $£$ I93,000) would bear scrutiny. But it will not. It is only between $\frac{1}{6}$ and $\frac{1}{7}$ per cent. of the capital invested. Quite a number of the undertakings are not debited with any depreciation at all. One must agree with Mr Schooling when he says that such a provision for depreciation of plant, machinery, etc., bought out of borrowed capital, and therefore not even paid for, is grotesquely inadequate. As no less than $£$ II5,000,000 out of the $£$ I2I,000,000 represents capital sunk in waterworks, gasworks, electricity supply, and tramways, the plant and machinery of all which undertakings have a short life, or at least an uncertain one, in view of their possible supersession by other improved methods, the chances are that they will be worn out or replaced long before the original debt incurred for them is paid off. It is not going beyond the mark to say that such plant and machinery is yearly depreciating by wear and tear (to say nothing of the prospect of supersession by other inventions, which affect the value of new and old plant alike) at the rate of 5 per cent. of their original cost. On that basis Mr Schooling submits a revised table showing the real position of all these municipal undertakings, for any other position claimed for them is false if full regard is not paid to the uncertain and temporary value of the ' assets.' This is how the undertakings stand on a 5 per cent. annual allowance for depreciation: 
Average yearly income (as before)

$\hbar^{1} 3,040,000$

Average yearly working expenses (as

$$
\text { before) .. } \quad . . \quad \ldots \quad \ldots \& 8,229,000
$$

Average yearly payments of interest,

etc., on borrowed capital (as

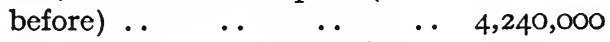

Corrected yearly amount for depre-

ciation, at 5 per cent. upon

Corrected average yearly expenditure

$$
\text { .. } \quad \text {. } 6,050,000
$$
Average yearly net loss
$£ 5,479,000$

I $8,519,000$

Thus it may be said that a loss of nearly $£ 5,500,000$ is annually being incurred by these $\mathrm{I}, 060$ ' reproductive undertakings', to meet which a sum of only $£ 378,000$ is allowed. Again, to quote Mr Schooling, 'they are worked by running into debt, which is constantly increasing, and the working of them, in place of being ' reproductive', constitutes an additional charge on the taxes.'

This conclusion is reached before any attempt has been made to survey actual municipal losses. But it was only fair to the municipalities that due regard should be given to their 'profits', and in this chapter an examination has been made into them which ends in the discovery that they are really losses, though not so called. To ascertain that municipal 'profits' are really losses thus leads us consecutively to losses about which there is no doubt, which not the most ingenious book-keeping can hide, and which stand 
out plain in the light of day. They may be briefly summarized.

A study of the Municipal Year-Book for 1906 yields the following results of the year's (I904-05) working of a number of municipal undertakings :

Of 378 waterworks 252 showed no profit.

Of 177 gasworks 40 showed no profit, and the surplus of 48 of those which did were not applied in relief of taxation, so that the taxpayers of 88 towns out of 177 obtained no benefit from municipal gas.

(It may be answered that the profits were less because cheap gas was sold, and it hardly needs saying that there is no reason why municipal works, if managed with the same economies, should not sell gas cheaper than private companies, but municipal traders under similar conditions have never yet been able to prove that they do. In exhibiting the exhilarating results of municipal trading, numerous comparative tables are prepared for the ratepayers, showing the low price of gas and electricity in a city where the municipality owns and operates the plants, and the high prices of the same commodities in another city where the plants are owned and operated by companies. These comparisons do not take into account some little factor like the price of coal and other raw materials, which makes all the difference in the world in the cost of electric light or gas, nor that a large proportion of the company gas and company electricity is manufactured in London, where the cost of everything is higher, while the municipal gas and electricity is nearly all manufactured in 


\section{DELUSIVE DEMONSTRATIONS OF PROFITS I 89}

the provinces - the greatest output being on and near the coal-fields. It is easy enough to make profits with an absolute monopoly by charging enough for the product. More than half the gas production of England is in the hands of private companies. The reduction in price of gas made by private companies in England has been as great, if not greater, and, as a rule, the price charged under exactly similar conditions is less than by municipalities. In short, in England, as elsewhere, the private companies have set the pace in enterprise, quality of gas, and in price. All enterprise in the gas industry has come from companies, because the companies have greater motive for enterprise. The municipalities may follow private enterprise; they have never been known to lead.)

But to continue. Of 58 street railway systems I3 showed no profit, and the surplus of 35 of these which did were not applied in relief of taxation, so that the taxpayers of 48 towns out of 58 obtained no benefit from municipal street railways.

Of 189 electricity works 64 showed no profit, and the surplus of 92 of those which did were not applied in relief of taxation, so that the taxpayers of ${ }^{5} 6$ towns out of I89 obtained no benefit through municipal electricity supply. This, however, is not surprising in the case of I 3 towns where the profits from electricity supply were so small as to make the works of quite negligible importance-that is, if the obtaining of profits is the sole object of Municipal Trading. These towns are : 
Profit on 1904-05 working. $\quad \measuredangle$ Barnstaple .. $\quad \ldots \quad 25$ Colwyn Bay .. . . 60 Farnworth .. $\quad \ldots 62$ Fulham $\quad$. $\quad$. 29 Gravesend .. $\quad$. 30 Hereford $\quad \ldots \quad$.. 2 Luton .. $\quad \ldots \quad \ldots 36$
Profit on 1904-05 working. $\quad £$ Nuneaton $\quad$. $\quad \ldots \quad 88$ Perth .. .. $\quad$.. 24 Rhyl .. $\quad . . \quad \ldots \quad 52$ Taunton $\quad \ldots \quad \ldots 62$ Tynemouth $\quad \ldots \quad \ldots 7$ West Hartlepool $\quad$. 2 I

A proper allowance for depreciation would wipe out these small surpluses, and there is no doubt, as figures already quoted illustrate, that the same result would follow if the larger systems were fully debited with a similar charge. As it is, in almost every case where a profit is shown from electricity works, it is arrived at only by ignoring or inadequately recognizing the factor of depreciation, which is juggled with in order that, by hook or by crook, a surplus can be squeezed out of the elastic figures. 


\section{CHAPTER XII}

THE TRAMWAY TANGLE

T EAVING the field of inquiry into municipal L 'profits', it may be advisable to look a little more closely into the circumstances which favoured the entrance of municipal councils into the conduct of the undertakings referred to. I will first take tramways as the service which, more than the others, has brought municipalities before the public eye as 'traders '; then gas (in conjunction with electric lighting and power), telephones, and the housing of the poor. The circumstances of each provide abundant object-lessons for American cities which are disposed to hanker after the possession of such undertakings.

The development of tramway legislation in the United Kingdom is full of the folly of encouraging Municipal Trading. Previously to I870 only a few tramways had been built, and these had been promoted under the costly and cumbersome method of submitting a 'private Bill' to Parliament. To obviate unnecessary trouble, waste of time, and expense, a Bill was passed which enabled tramway promoters to apply directly to the Board of Trade for what is called a tramway 'Pro- 
visional Order.' Such an Order is practically a franchise, and is provisional only in the sense that it has to be formally confirmed by Parliament before it can be acted upon. This arrangement was embodied in the Tramway Act of I870, and, so far as it simplified and cheapened procedure, the Act was welcome. In other respects, however, the Act was not so well advised, since it established precedents, which have hampered electrical enterprise to a degree not fully recognized by those who have not been engaged in the effort of carrying out tramway schemes in England. When the Tramways Act was drafted the Government of the day was in a zealous reforming mood. The inspiration of this enthusiasm lay in the misdeeds of certain gas and water monopolies, which had taken a too short-sighted advantage of the too liberal powers granted to them in former years. There was a strong demand that the public should be protected from similar abuses of power, and, as tramways were in essence a monopoly, Parliament was naturally inclined to include protective measures in the Act. This it did in two ways :

I. By giving each local authority the right of vetoing any tramway scheme within its district; and

2. By imposing a tenure of only twenty-one years on tramway concessions, and giving each local authority the power of purchasing the undertaking at scrap value (otherwise called 'old-iron' or ' marine-store' prices) when the period of tenure was at an end.

Not a word was said in the Act regarding the working of tramways by local authorities. It was, in fact, 
expressly pointed out by Mr Shaw Lefevre, when the Tramway Bill was introduced in I870, that its underlying principle was to empower 'local authorities to construct tramways, but not, of course, work them.' The Act merely contemplated that the authorities should be owners of the tramways, and that they should lease them to companies. But as time went on, and Municipal Trading became popular, local authorities eluded the intentions of the Act by pleading that they could not obtain satisfactory leasing arrangements. This pretext did not always succeed, but where it did precedents were formed for the later development of municipal operation of street railways. This was done by the simple expedient of inserting a clause in the private bills of local authorities, giving them power to work the systems, and a great Socialistic movement affecting millions of private capital was thus initiated, almost unawares, by indirect legislation. Municipal working of tramways remains unrecognized by general legislation, and it has never even been discussed in Parliament as a general principle. It has covertly crept into use by individual towns obtaining the sanction of parliamentary committees to work their systems, and other towns were quick to follow their example. The securing of the right to operate tramways solely by private bills is a curious illustration of how easily British municipalities can obtain power over and above those laid down and never contemplated by general statutes. To the extent to which the Tramway Act of 1870 was intended to limit the participation of 


\section{I94 THE DANGERS OF MUNICIPAL TRADING}

municipalities in tramway control, therefore, it has been a failure. But private bill legislation has long ago proved a serviceable loophole through which Acts of Parliament may be avoided.

So long as Parliamentary Committees declined to grant the right to municipalities to operate their systems unless they failed to find a lessee-which was their rule up to I896-the relations between local authorities and private companies were not materially changed. But the general acceptance of municipal working altered a municipality's attitude towards a company. It was no longer a case of the one being controller and the other submitting to control. The local authority became a potential competitor. There was no question of the working franchise being renewed to the company on the expiration of the latter's existing tenure, as intended by the Tramway Act. The municipality was to become the sole successor to the business, and the company was to be extinguished. Pending that event it was hardly possible for a local governing body to confine its relations with a company to fair and proper supervision. A company, whilst its franchise lasted, in many towns suffered from the disadvantage of being regarded as an interloper, and incurred feelings of deep jealousy and hostility on the part of the municipality.

It is safe to say that the then Government had no anticipation of the actual effect which municipal privileges would have on the future of the tramway industry ; and it is equally safe to say that succeeding Governments 
have made but slow efforts to improve matters now that the unfortunate incidents of the veto and the conditions of tenure have been felt over and over again. The attempt to regulate the powers of tramway companies in the public interest led to restrictions which were excessive, and so defeated its own intention by retarding the development of an important public service. In justice to the Government it must, nevertheless, be admitted that the full strangling influence of the Tramway Act was not felt until many years after I870; indeed, not until the dawn of electric traction as a commercial possibility. That was about I89o-twenty years after the passing of the Act-and close upon the time when numerous tramway franchises were expiring. At the same period, moreover, the important movement of municipal bodies in the direction of trading enterprises had already begun, and was making steady strides in popular favour. In the coincidence of these three things-one legislative, one industrial, and the third social-one finds the causes of the present condition of electrical traction in England. To understand how this trinity of causes co-operated to produce a single result in putting back the tramway clock in England for several years, all that is necessary is to consider the position of a tramway undertaking which, in or around the years from I8go onward, was approaching the end of its period of tenure. Confronted with the fate of expropriation in a few years' time at its 'then market value', with no allowance for goodwill, or compensation for compulsory purchase, anything like fresh 


\section{I96 THE DANGERS OF MUNICIPAL TRADING}

capital expenditure on the undertaking was out of the question, and the efforts of the managers were naturally concentrated on reducing expenses and husbanding revenue, so as to meet, as far as possible, the inevitable capital loss through the sale of the undertaking at oldiron prices. The unhappy effect of the limited tenure arrangement was to force tramway undertakings into a premature condition of senile decay. No money (except what was absolutely necessary) was spent on the renewal, or rolling stock, or permanent way; the cars were even grudged fresh coats of paint, and the conductors new uniforms and new sets of buttons, so dear to the heart of the public. The service of cars was limited as far as possible; extensions were not to be thought of ; and, in short, enterprise, as it is generally understood, would have been a business absurdity. The last years of a tramway were, therefore, years of insufficient and inefficient service. The public grumbled. They called upon the tramways to electrify their systems-a vain demand, when there was no promise of renewal of tenure for even another twenty-one years. As the undertakings would soon fall into the hands of local authorities, it was natural that public opinion should turn to them for reforms which were apparently unreasonably refused by the private companies.

This expression of public opinion was not made in vain, and it has placed the development of interurban electric traction in a difficult position, from which it will probably not emerge for a considerable period. One municipality after another took over its local 
tramway system when the period of tenure was concluded; and one municipality after another decided to adopt electric instead of animal traction. This latter change was not, however, carried out with anything like rapidity. Even the most progressive of municipalities, and those most enamoured of trading projects (such as Glasgow), dallied over the problem of conversion for a quite unnecessary period; and in the hands of the local authorities the progress of electric traction has been extremely slow. Mr E. Garcke ${ }^{1}$ has shown that in 1896 , which may be regarded as the beginning of the period of electric traction in Great Britain, there were many British towns and aggregations of towns with populations of I00,000 which had no tramway facilities at all. At the same period, all the cities of the United States of I0,000 inhabitants and over, and many of the smaller towns-exceeding 5,000 inhabitants-were served with street railways. With good reason, therefore, British capitalists considered that there existed profitable scope for the development of electric traction. 'American tramway experts', remarks Mr Garcke, 'thought so too. The officers of English tramway companies will recall the proposals they received from American financiers to electrify and extend their tramways; but when these American experts became acquainted with the conditions under which the business could be done, they, for the most part, went back to the States much wiser, but certainly not much impressed with the ways of the old country.'

1 The Times Engineering Supplement, July II, Ig06. 
So far as interurban electric lines were concerned, the part which the local authorities played was for many years practically nil. Each local authority thought only of its own district, as it was naturally inclined to do. Not until the example of other countries was afforded, combined with the successful exploitation of some interurban systems by private enterprise in England itself, did the local authorities begin to realize that the conversion of tramways to electric traction did not merely enlarge the carrying capacity of the old system, but greatly enlarged the area over which the tramway systems should, in the public interest, extend. With horse traction the limits of each local authority were, roughly, the limits of economical working. With electric traction the parish became a mere item in a comprehensive system, which might extend over a whole country.

It remained, therefore, for private enterprise, in the face of discouraging legislative conditions and the opposing trading ambitions of municipalities, to demonstrate to the public the value of those extensive interurban systems which electric traction had rendered possible. The efforts of private capital toward this end were directed through two channels. In the first place, old tramway undertakings (those approaching the end of their tenure) were acquired in the hope, or the promise, that the local authorities concerned would defer purchase until the end of a certain period, or grant a lease to the company. In the second place, extensions are promoted as links in a comprehensive system. 
In both these operations private enterprise was materially assisted by the operation of the Light Railways Act of I886, though it introduced railway as well as municipal opposition to the extension of interurban systems. It will, therefore, be clearly observed that private enterprise in English street railway undertakings has had many more difficulties to contend with than in America. It has practically been kept out of the rich districts by the cities taking over the plants for a song at the end of short leases, while the virgin districts in England which are worth anything are few and far between. Where there is a virgin district, however, and a company enters it first, acquiring the best routes, they have to face the danger of the municipality, impatient at the company's success, entering into competition with them rather than wait until the expiry of the company's franchise, when they could take over the system. This is the experience of the Oldham, Ashton, and Hyde Electric Tramways Company, Limited, which was formed to run electric street railways in a district where they had not before been laid. The various municipal authorities concerned feared to avail themselves of their powers to run the lines themselves, and hence did not oppose the private promotion. It was quite a speculation, of which investors fought shy, and the company conducted the system on modest lines in the hope that, once successfully established, there would be no obstacle to its making the natural extensions to that system which the successful management of the existing lines justified. But when the 
municipal authorities found that the company had made a moderate success of its undertaking, their jealousy was aroused, and instead of allowing the moderate extensions the company contemplated, several of the local authorities promoted tramways of their own, choosing routes which the company avoided as not promising to be remunerative. They have, of course, failed to yield a profit. On the contrary, they are a burden on the taxes. So that the company is doubly hit by the failure of the municipal tramways, being debarred from extending its system, and suffering competition from municipal lines, to the losses from which it has to contribute as a taxpayer. In fact, the municipal tramway failure in the district has meant the levying of a tramway tax in one town (Ashton) of Is. $3 \frac{1}{2} d$. in the pound, or an extra I3 per cent. on the assessment; and in another town (Hyde) of $9 d$. in the pound, or an extra $4 \frac{1}{2}$ per cent. on the assessment.

This is a case of municipalities agreeing to combine to thwart the success of a company which was more courageous than they in tapping an undeveloped district. In other cases private enterprise has been allowed to link up tramways in areas where the local authorities could not agree as to which particular local authority should manage the enterprise. Each local authority had to be separately considered; its opinions, its prejudices, and its ambitions carefully studied. Each of the local authorities, it should be remembered, had the power to veto any of the schemes of the tramways company for the renewal of tenure, and each of them 
had to be separately persuaded not to use this power. The history of such undertakings in England illustrates the difficulties involved in arranging intercommunication facilities between neighbouring systems owned respectively by companies and local authorities. The municipal systems occupy, for the most part, the areas of densely populated towns; and their owners have naturally a tendency to regard them as self-contained, and, therefore, superior to outlying systems. From the present state of municipal opinion with regard to private enterprise, it seems Utopian to expect the initiative of better things from local authorities themselves. The necessity for free intercommunication between neighbouring tramway systems is already a truism among electric traction companies; but local authorities, not being business organizations, do not treat the question on the same broad commercial lines. There seems every reason to anticipate that the local authorities will not, save in rare cases, be readily induced to arrange running powers with tramway undertakings touching their borders. The public interest, nevertheless, demands it, and points to the necessity of altering the state of the law in order to achieve it. When two neighbouring railway companies do not agree to running powers for which there is a clear public necessity, Parliament can enforce mutual working arrangements. Now that extensive tramway systems of a nature similar in character to railway systems are being built up, common-sense requires that Parliament or the Board of Trade should have the same 
power to enforce intercommunication where various tramway systems are contiguous.

The difficulty of effecting anything like efficient intercommunication arises from the parochial spirit which municipalities evince in their dealings with each other, perhaps more strongly than in their relations with companies. Next-door neighbours are not always the best friends, and municipalities are, in this respect, very human. The natural pride of each of them in their municipal achievements has an obverse in the natural jealousy of the achievements of others. There is no necessity to dwell on this well-known aspect of municipal life, but it must, at least, be referred to, in order to explain why municipalities have not done much to develop isolated tramway systems into interurban networks. The old familiar difficulties of getting several local authorities to work harmoniously together in a drainage or water scheme are experienced again in connection with tramways. They are, indeed, exaggerated beyond their usual intensity, because questions of profit on municipal outlay are involved in mutual enterprise. In this matter also local authorities are conspicuously human. It is thus difficult for municipal bodies, whose sympathies are inevitably directed to a single special area, to carry on enterprises which, to be properly conducted, must ignore local boundaries, and spread freely in all directions. They show, also, how little in the way of interurban tramway development may be expected to arise out of the initiative of the local authorities. In addition to this criticism 'by results' there 
are many objections to be urged, on the grounds of inexpediency and of principle, to any local authority carrying on trading operations within the areas of neighbouring authorities - as must be done if municipalities are to become promoters of comprehensive systems of electric lines. Whether the ratepayers of $\mathrm{A}$ should be taxed to provide tramways for $B$, and whether the pennies paid by the public to $B$ should be applied to relieve the rates of $\mathrm{A}$-such are the questions opened to us as soon as a local authority trades beyond its border. And all the arguments against municipal speculation within the limits of each area become emphasized when the area is overstepped. Experience seems to indicate very clearly that in the majority of cases the municipal control of a tramway system implies an obstacle to the development of that system to become part of an extensive interurban system. In London, to go no further, the municipal tramways only run to its borders, whilst those of private systems continue, though changing is essential. How, with such restrictions as these, and with such local interferences, there could have been established the great interurban tramway systems centring in Boston, Chicago, Detroit, Pittsburg, and Cleveland, to say nothing of New York and Philadelphia, and a dozen other cities which will at once suggest themselves, I do not know. Could anything but private enterprise have linked up Minneapolis or St. Paul ? I think this phase of Municipal Trading deserves special attention, for herein it shows one of its greatest weaknesses. Even Mr Bernard Shaw acknow- 


\section{THE DANGERS OF MUNICIPAL TRADING}

ledges that the taxpayer has a real grievance as things now stand. 'If he tries', says Mr Shaw', ' to establish electric tramways from county to county, or to reduce the cost of electric power (still ridiculously expensive in its application to domestic heating, for example) by making the generating centre supply a whole province, he can do so only through the local authority or through a commercial joint-stock company. If, for the sake of cheap service and public control, he tries the local authority, he finds that its power, like that of the witch who cannot cross running water, stops at a boundary which dates, probably, from the Heptarchy. If he submits to the prices and the power of the joint-stock company, he finds that the local authority vetoes the tramway, or has a virtual monopoly of power distribution within its own area. So it ends in his going without.'

The instrument the municipalities possess, by the exercise of which they show their jealousy of one another, is the same as that which they use against the private promoters-their power of vetoing tramway schemes within their own respective areas. In London, where the local authorities and the road authorities, for the purpose of the Tramways Acts of I870, are not identical, there is a double veto, which each can employ against the other, and both can employ against third persons. Both the London County Council and the Metropolitan Borough Councils have used their veto frequently. The corporation of the City of London

1 The Common-Sense of Municipal Trading, chapter vii. 
also possesses a veto, and has invariably used it against all comers. 'The right of veto is exercised not so much with the desire to destroy a projected enterprise, but rather to exact the utmost conditions which a promoter will accept sooner than abandon the project. When a scheme is proceeded with in spite of these exactions it is taken as evidence that the conditions imposed have not been exacting enough; and whenever the operating company has occasion subsequently to ask the local authority to approve anything, the company is expected to offer more than commensurate consideration, although the object for which the approval is desired may be primarily for the benefit of the public. All these obstacles imply increased capital outlay or increased working costs, and perhaps both. If, notwithstanding these conditions, the company earns a moderate profit, it is accused of striving only after dividends to the prejudice of the public. If non-success of the enterprise follows, then the company is accused of being overcapitalized and mismanaged, and it has come to be considered an impertinence for a company to offer ever so mild a protest ${ }^{1}$.' The use of the veto has had disastrous effects on private enterprise in many districts; it has led to utter stagnation of personal initiative. Good schemes have been barred by local authorities out of pure caprice or prejudice. Other schemes have been allowed to proceed under barely tolerable conditions; the undertaking has been crippled from the

$1 \mathrm{Mr} \mathrm{E}$. Garcke, The Times Engineering Supplement, July $25,1906$. 


\section{THE DANGERS OF MUNICIPAL TRADING}

start by the high price municipalities have exacted for their consent. Others, again, have been withdrawn by the promoter because it was found impossible to agree to the extortionate proposals of the governing bodies. Some expressions of opinion on the veto may be quoted. The chairman of the Parliamentary Committee which considered a scheme of tramways promoted in Scotland said: "The committee desire to put on record that in their opinion the original scheme was a good one, and calculated to be of much use to the district; but it has been so mutilated and loaded with conditions by conflicting interests and the excessive demands of several local bodies, that it now appears to the committee to be wholly unworkable.' Mr Albert Gray, counsel to the Chairman of the Committee of the House of Lords, referring to the arrangements made by promoters to overcome the veto, expressed the opinion, in Igoo, that the making of these bargains 'probably must lead to corruption in some form or other.' In I902 Mr Chaplin, at one time President of the Local Government Board, stated that "what local authorities would describe as conditions are regarded by promoters-and very often, no doubt, with good reason-as neither more nor less than blackmail. This has been the subject of great complaint for years, and I do not think I should be going too far if I said that on several occasions it has led to considerable scandals.' The Royal Commission on London Traffic, during its sittings in I902-04, heard much evidence regarding the abuse of the veto, to the general effect that it had been used, in many cases, in an unreasonable 
manner, with mischievous results, and without due regard to the interests of the general public. They were unable to ignore the subject in their report, wherein they expressed the opinion that " there is no doubt that tramway development has been seriously checked by the operation of these vetoes; and, although it is not suggested that any unworthy use has been made of them in London, it is clear that the veto is sometimes exercised without due regard to the importance of establishing through tramway communication.' They came to the conclusion that the best course was to abolish the veto in all cases, and considered it unreasonable that one portion of a district should be in a position to put a stop to the construction of a general system of tramways required for the public benefit, without even allowing the case to be presented for the consideration of Parliament.

This veto and their powers of acquisition and general control make municipalities masters of the situation so far as tramways are concerned, and having succeeded in routing private enterprise in this direction, they were, until lately, disposed to rest upon their oars in triumph and self-congratulation. The vast, elaborate, and expensive electrical tramway systems they had constructed were theirs-unalterable, municipal institutions. Tramways, indeed, from the point of view of municipal authorities, were the last thing in street locomotion. Their cars were a permanent, standardized form of transit by which they decreed the public should travel; whilst in return for the privilege of being in- 
jured or killed in, on, or through a municipal car, the public are denied the same liberty to take legal action against municipal authorities that they have against private companies ${ }^{\mathbf{1}}$.

This belief in the immutability of municipal works has been rudely disturbed by the ' hoot' of the motoromnibus, for private enterprise, hide-bound by the municipalities in the direction of tramways, has availed itself of their development by running them wherever it can. These useful vehicles are already becoming a thorn in the side of local authorities, who marshal their forces in strong opposition when the railroad, for instance, asks for powers to introduce motor-omnibuses in connection with their lines. As tramway owners, the municipalities want a complete monopoly of the street passenger traffic, fearing that motor traction will prejudicially affect their receipts. When the North Eastern Railway sought and obtained authority to run motor-omnibuses, Parliament was asked to limit the railway company's powers by providing that if the

1 The Public Authorities Protection Act, passed by Parliament under pressure of the Association of Municipal Corporations, prohibits any action being brought against a municipality, by a person, for instance, injured on a borough tramway, more than six months after the accident; whereas if the accident happen on a company's tramway, the injured person would have had six years in which to sue. Further, an unsuccessful plaintiff against a municipality is penalized by having to pay to the municipality a higher scale of costs than those awarded between private parties. In ordinary litigation, in fact, the Courts have a certain discretion to withhold costs altogether. There are other special provisions in the Act which make litigation with a municipality risky and costly. 
vehicles traversed a district where there were tramways owned by the local authorities, the railway company should be prohibited from picking up intermediate traffic. This attempt to protect municipal enterprise from fair competition failed. It happens, however, that in Glasgow and other provincial towns the anomalous position exists of the governing authority having the power to license such vehicles, permission to run which they can, and do, refuse if they are intended to ply on routes served by the governing authority's tramways. The position of the London County Council, in being at one and the same time an administrative and a trading body, with, most unfairly, powers over persons who are their competitors in such trading, is particularly anomalous. For instance, under the provisions of the Public Health (Animals) Act they can close the stables of their competitors, the omnibus owners. Under the Buildings Act they can prevent their competitors putting up the buildings they require, or harass them in their requirements. Under the Motor Act the Council can lay down the speed at which their competitors may run their vehicles, and they can regulate the speed in the interests of their own electric trams, rather than in the interests of the general public or of motorists. The principle is an important one, for it raises the question how far a local authority can bar the running of vehicles which may be proved to be necessary in the public interest, because they would compete with a municipally run tramway system. One municipality (Croydon), however, for its own purpose, wanted to run 
motor-cars, but in their seeking power to do so, it transpired that the cars were to be run over a number of routes along which a private company had obtained power to construct tramways. This revealed their object to be to steal a march on the company, and it did not succeed ; the Parliamentary Committee regarded the scheme to be an ill-considered one and rejected it. But other municipalities have since succeeded where Croydon failed, for being unable to set back the popularity of the motor-omnibus by opposing their running, a number of them have been busy of late in obtaining powers to run them in connexion with their tramways, following the usual municipal policy of baulking private enterprise of reaping any benefit from their initiative in promoting new forms of enterprise. In a year or two, no doubt, there will be as many motor-omnibuses running, both municipal and private, as there are tramcars. Then will arise the question as to how far the enormous cost of municipal tramway equipment is likely to be wasted through the lack of foresight displayed by the municipalities in building great tramway systems as though for all time, when no sooner have they attained a certain stage of efficiency in working than their further success is menaced by the running of a powerful new competitor for public favour which may, in the end, reduce them to obsolescence. Perhaps, after all, private enterprise has to be congratulated on the cupidity of the municipalities in taking over their tramway systems if the latter fail to withstand motor-omnibus opposition. 


\section{CHAPTER XIII}

THE STRANGLING OF THE ELECTRICAL INDUSTRY

THE municipal attitude toward motor-omnibuses 1 as rivals to their tramways, first holding them in light esteem, then antagonistic to their progress, then grudgingly recognizing their importance, and finally making haste to acquire power to run them themselves only when private traders had proved their worth, is similar to that which they showed toward electricity in relation to their gasworks. Like the motor-omnibus, electricity, when it came on the scene, threatened to supplant a service of which they held a monopoly. There was no doubt about the policy to be pursued. Electricity must either be killed or captured. But electricity proved to be a force which was not to be crushed out of existence by the hostility of local governing bodies : its capture was less difficult. Armed, therefore, with the powers obtained by the Electric Lighting Act of 1882 , the municipalities have set the pace to its development, and a very slow pace it has been. Put in a nutshell, the municipalities acquired such a control over the new industry that a district was entirely at the mercy of the governing authority as to whether a single 
electricity unit should be generated within its area. The object, naturally, was the protection of the monopoly of their gasworks, and also to leave the field open for the municipality to enjoy a similar monopoly of the new illuminant if they chose. By virtue of the Act referred to no electric-lighting company could carry on business in any locality without the sanction of the municipality, who themselves had the option of obtaining the same powers by which the private company could be ousted; or even if the latter were allowed to exist, the municipality could step in within a certain period, after the private company had proved the utility of their business, and expropriate the entire concern at its bare value. By such powers the municipalities could keep private enterprise out altogether, or admit it under onerous restrictions. They have done both. But after electric lighting had become quite common in America, it dawned upon the councillors that their gas monopoly could not last for ever, and that either they must adopt electricity themselves or let in the private companies, who had been offering to do the business for years past on reasonable terms. Accordingly, there came a municipal boom in electric light, and members of the municipalities made many boastful speeches glorifying their progressive spirit and their devotion to public needs, so that the actual truth -namely, that their foolish obstruction had kept English towns far behind those of America and Europewas lost sight of by most people. However, at that time it was generally accepted as gospel by aldermen 
and councillors who 'discovered' electricity, and who patronized the helpless foundling, that they had really secured a magnificent ' asset' for the ratepayers in the shape of a monopoly of electric lighting, a business that would grow and prosper. But having gone thus far with the new illuminant, it has turned out that many towns would have cheerfully left electric lighting to private syndicates if their governors had known what a fierce competitor the cheap English gas was going to be when the introduction of the Welsbach incandescent burner and mantle came about. Hence to-day both municipal and company gas have proved the more lucrative, and many municipal electricity works are suffering as much from the successful rivalry of gas as from their bad management. It is, however, a wholly optional form of competition, since-in towns where gas and electricity are in municipal hands-the same agency which pulls the strings of the one pulls the strings of the other. The efficiency of either can be added to or lowered as the wisdom of the municipality dictates, so that gas may easily be made to show a profit by the simple expedient of not supplying a satisfactory electric light or raising the price, whereupon consumers turn back to the illuminant they abandoned. The policy of starving one undertaking at the expense of another is followed in Prussia. There both the railways and canals, competitors for goods traffic, are in the hands of the State, and the former are kept at a comparative low efficiency, whilst the canals are afforded a preferential treatment by superior equipment and low 


\section{I4 THE DANGERS OF MUNICIPAL TRADING}

rates, which enable their competition to be felt by the railways. It is true that two undertakings offering similar service, though with a different method or article, may be profitable, even if both were municipally managed, but the temptation to juggle with one or the other is ever present. From this point of view, in towns where municipalities own gasworks, and where the electric lighting is managed by private enterprise; the latter solely, and not the taxpayer, would be the losers if gas has a greater vogue; on this ground alone, therefore, both services ought not to be in municipal hands. There is another reason why electricity works should be confined to private operation; though, as time goes on, and the use of electricity becomes more general, this may lose force. Can electricity supply be termed a public service? It is at least disputable whether electric lighting can be so classified as yet. Most people use gas, and it may be conceded, for the purpose of argument, that on that ground gas-supply is a general service, and should be in municipal hands; but nothing like the same use is made of electric lighting, and for the municipal control of the latter, therefore, the same argument cannot be maintained. Really, municipal electricity works merely provide a convenience to a fraction of the population. Thus, Battersea, with a population of 174,800 , has its electric light, costing nearly $£ 200,000$, only used by, relatively speaking, a small number of people. Therefore, nearly the whole of the taxpayers of this district get no enjoyment for the expenditure they have contributed to the electricity works. 
Fulham, another London district, with a population of I56,000, has a municipal electric installation, which cost the ratepayers $£ 260,000$, and there are only $I, 792$ consumers. In cases where electric lighting shows a profit, and the surplus is applied to the relief of the taxes, the few are really contributing to the reduction of the rates of those who use gas, and who have, therefore, had no share in promoting the success of the electricity works. Thus a question arises as to the fairness of this, unless a profit can be extracted from the gas undertaking, to be similarly applied.

Without entering into the question of the relative merits of gas and electricity for lighting purposes, there is no doubt that the former maintains a very strong position, through the improved burners invented of late years, added to prior establishment, and, consequently, fidelity of the public to an illuminant to which they have for so long been used. Gas ousted the candle and the lamp, though not wholly, but electricity has not materially affected the use of gas. On the surface, it would seem that it has failed on its merits as an illuminant; but I have already pointed out the true reason for the backwardness of electricity in obtaining general favourthat it was no sooner ushered into existence as a practical commercial industry than the shadow of the municipalities fell across it, and has dogged its development ever since. The rapid growth the industry would have had was indicated by the readiness with which capital was volunteered at its birth, ere repressive legislation intervened. During I88I to I883 electricity 


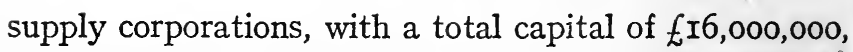
were registered, as against a sum of under $£ 800,000$ before $188 \mathrm{I}$. With the passing of the Electric Lighting Act of 1882 this outburst of activity was abruptly and entirely throttled, so that during the years $1884-86$ the capital invested in the industry fell to the figure at which it stood before I88I. As soon as the effect was understood of the short tenure for which a company could retain possession of its undertaking, at the expiry of which the local authority could step in and acquire the concern at its bare value, private promoters generally declined to incur the overwhelming risks which the carrying on of the undertaking entailed. Franchises obtained in $\mathrm{r} 883$ were practically abandoned and subsequently cancelled, and the corporations which secured them were amalgamated or wound up. Hence in a very short time the Act that was intended to 'facilitate' the supply of electric light effected an entirely contrary purpose, for it succeeded in extinguishing the industry for some years. Some relief to the onerous conditions was obtained in $\mathrm{I} 888$, when an Act was passed which doubled the period of tenure from twenty-one years to forty-two years-a vital change, which rescued electric lighting from the slough of decrepitude to the plane of practicable enterprise. The terms of expropriation by the municipalities, however, were not materially changed by this amending Act; but the longer life it secured to a private corporation, by which municipal annexation was warded off to a period which gave the concern a chance to prosper and 
allow its management some reward for their labour, stimulated a revival in the electrical industry. In other respects, however, the local authorities were able to retain their hold over the industry. The latest date, for instance, when a private corporation can give notice to the local authority to apply to Parliament for a Provisional Order (or a franchise) is July I, whilst the local authority has until the November following-a period of five months-in which to apply for a similar Order. They may, and do, refuse consent to the private company applying if they fail to wring from the company sufficiently stringent terms. They may, and do, apply for a Provisional Order themselves-and not act upon it. No less than 342 Orders were obtained by local authorities between I888 and I900, against only I23 taken out by companies. The latter were acted upon at once; many of the former were not, and remained unused beyond the two years limited by the Board of Trade for the commencement of work. Indeed, several Orders obtained by local authorities in I89I and 1892 had not been put in operation in Igoo. The outcome of this dog-in-the-manger policy of local authorities, in neither providing a district with electric lighting themselves nor letting in a private company to do so, was that only 250 towns had any electricity supply available, notwithstanding that there are over 700 gas undertakings in the United Kingdom.

The roping in of the British electrical industry was neither the fault of the men of science, engineers, nor capitalists, but ' wholly and solely the fault of a Govern- 


\section{I8 THE DANGERS OF MUNICIPAL TRADING}

ment which, like all British Governments, but unlike all foreign ones of any consequence, went blundering into a subject which it knew only as a text for uninformed debate, without consulting men who really knew, and without regarding even the general principles of commercial prosperity.... Now, as then, at every stage promoters are thwarted by Parliament, by municipalities, by chaotic survivals from legislation passed before electric power was heard of, and by an equally chaotic overlapping of different jurisdiction.' ${ }^{1}$

Of late years private enterprise has broken away from the limited field presented for its activities by the municipal area, within which the distribution of supply, as laid down by the Electric Lighting Acts, is confined, and wherein the power-house must be situated. The advantage of possessing a longer life before a municipality can expropriate cannot be fully enjoyed, because private electricity works are circumscribed in their development by the limitations of that area. The output and the nature of the load are alike restricted. There is no scope for extensions. The municipal boundary may exact that the power-house be situated where the cost of land is high, the poundage heavy, and water and coal dear. Many power-stations are thus situated, especially in London, where one supply company yielding 6 per cent. dividends pays 25 per cent. of its divisible profits in municipal taxes. Cabined, cribbed, and confined by existing general legislation, the energies of electrical companies seemed likely to be curtailed in

1 The Times, October 24, 1906. 
a way which would permanently retard any real growth of their concerns. But the demand which has risen of late years for cheap electric power by railways and tramways, chemical, textile, and engineering works, shipyards, docks, and collieries, and every type of industry, completely changed their outlook. Schemes were evolved for establishing huge generating stations capable of supplying all these needs, with a sphere of operations extending over counties instead of single districts or towns. Existing legislation, however, barred such enterprise, and fruitless were the attempts to induce the Government to amend Acts wholly out of harmony with the progress of electrical engineering, so that development could proceed on these lines. Recourse had, therefore, to be had to special legislation by private promoters seeking Parliamentary sanction to undertake the manufacture of electric power in bulk for distribution over wide areas. The municipalities speedily awoke to the fact that in this move their common enemy, scorning the boundary of a single local authority as not affording it sufficient breathing space, was bent upon expanding over the areas of a group of them. The first of these power bills was promoted in 1898 , and contemplated the erection of a large generating station in the Midlands, from which an area of about 2,000 square miles would be supplied. Power in bulk was to be furnished to municipal and company holders of electricity franchises, who would distribute the power to consumers, whilst sanction was asked to supply current direct to factories and to other power 
users. The municipalities came into line in strongly organized opposition, and finally crushed the proposal, through the machinations of the Association of Municipal Corporations, an organization which employs the methods of the trade unions to gain their ends. Eventually, however, a number of electric-power bills succeeded in overcoming the antagonism levelled at them by the municipalities ; but their success was considerably tempered by the restrictions placed upon the operation of the companies as the result of this opposition. Large towns have been excluded from the areas of the companies' power-supply, whilst the companies are unable to supply current direct to a power consumer in the area of an authorized distributor (a municipality) without the consent of the distributors, which practically means that a large power consumer is barred from having dealings with a bulk company if the municipality objects. On precedents thus created have been based subsequent statutory powers granted to companies, so that 'the character of the undertaking organized to secure a general distribution of cheap energy for industrial purposes, as well as an all-round reduction in the cost of electricity for lighting, has been determined, not by engineering conditions, nor the interests of the public, but by the parochial spirit and the ambitions of local authorities who failed to take a broad and statesmanlike view of the movement.'

Standing alone in being free som unfair municipal

${ }^{1} \mathrm{Mr}$ E. Garcke, The Times Engineering Supplement, May 2, 1906. 
interference is the Newcastle-on-Tyne Electric Light Company, the pioneer and most successful electricpower undertaking in the United Kingdom. The cheapness of coal, and the concentration of industries round about Tyneside, in part accounts for its success, the company having within its area a large demand for cheap power in bulk from numerous shipyards, engineering shops, and factories. They were able to meet this demand by the municipalities concerned recognizing that they themselves, in the exercise of their electriclighting franchises, could only provide limited facilities to meet manufacturing requirements. It might be submitted that a huge generating station supplying energy, as in this case, over the whole area of the Northumberland coal-fields, and embracing the territories of a score of municipalities, would be equally successful if municipally operated. This would only be a tenable proposition if the local authorities concerned were capable of amicably joining hands and undertaking power generation on a scale and magnitude far beyond the capacity of their own single-power plants. As has been clearly shown in the chapter on street railways, the parochialism and petty jealousies of local authorities stand in the way of any such cooperation.

The Newcastle Power Company has been able to manufacture energy in bulk so economically that its average selling price per unit- $\mathrm{I}^{\circ} \mathrm{0} 3 d$.-is less than the cost of the production-I.22d.-generated by the Tynemouth municipality, half of whose output is used 
for the municipal tramways. The comparison is submitted to show the economic advantage of obtaining a supply in bulk from a power company. It also casts a sidelight upon how electrical power development on the Tyne would have fared had all the other local authorities acquired electric lighting franchises, and operated them as separate undertakings. The Tynemouth municipality, indeed, recognized the advantages of having at its own doors facilities for power-supply superior to its own, and is now buying energy from the company under an arrangement which will mean a saving of $£ 2,000$ a year to the taxpayers. A London urban authority in a similar position is the Willesden Urban District Council, which disposed altogether of their electric-light station to the North Metropolitan Electric Power Supply Company, from whom it now buys power in bulk at a much lower price than the municipal power-house could generate it.

It does not always happen that a private purchaser is at hand to take over an unprofitable municipal plant. Bath, some three years ago, offered its electric-lighting undertaking for sale, after losing many thousands of pounds in a disastrous attempt to earn profits for the citizens. The concern was then in such a bad condition, and the expensive plant laid down so depreciated in value, that no syndicate or individual could be prevailed upon to make an offer for the business as a going concern which the council could accept. As a compulsory alternative a large sum of money was borrowed to construct the system. It still shows an annual loss 
on working. In I906 the loss was $£ 338$. . No provision has been made for depreciation of plant or mains, and on the present capital expended a charge of 3 per cent. for the renewal of machinery and mains would, it is pointed out, swell the loss to over $£ 3$,000 on the year. Bath, however, has profited by her failure to handle her electric-lighting undertaking, having readily granted a franchise of her street railways to a private company, which is performing good public service. From the more moderate sections of town and district councils are heard now and again demands for the sale of waterlogged municipal undertakings to private enterprise as the best means of getting rid of a bad investment of public money. It might almost be said to be a movement on the part of a number of local government bodies to try and use private enterprise as a sort of hospital for their diseased trading undertakings. There is naturally little ardour on the part of private enterprise to pay fancy prices for obsolete plant laid down after years of bad management. As I have already shown, in Great Britain the capitalists are now more attracted toward the large electric-power schemes which have authority to supply energy over areas of hundreds of square miles than to town-lighting businesses in which the municipalities engage under the delusion that by doing so the last word on electrical progress has been uttered.

The readiness with which manufacturers in the Newcastle district have availed themselves of a cheap power-supply in bulk from a company conclusively 
shows that when private enterprise is afforded the opportunity of performing 'superior public service' it is fully equal to it. The enterprise of municipal electricity works, which, figuratively speaking, so far confines itself to supplying current in teaspoonsful at a much higher price than power companies charge, certainly compares poorly by the side of the Newcastle company's public spirit. 'It must be borne in mind that, in order to obtain consumers, the power companies have frequently to transmit their power several miles, involving heavy capital outlay on cables and an appreciable maintenance charge. If the power companies can afford to supply at the low figure of between $\frac{1}{2} d$. and $\frac{3}{4} d$. per unit, in spite of the distance over which the power has to be transmitted, surely the municipalities, with the demand for energy at their very door, can do so even better. What, then, is the reason that municipalities have not yet been in a position to offer the low rates for power such as the power companies are now contracting for? The answer seems to be twofold: (I) They have not realized the possibilities of power-supply on a large scale, and are consequently not prepared for it; (2) they have hitherto hesitated to lay out the large sums of money required for adequately dealing with the problem.'

There is no doubt that many industries, great or small, throughout the country, could be enormously facilitated if electric power could be 'laid on' to them

1 Mr William Hodgson, chairman of the Salford Municipality Electricity Committee. 
in the same way as gas or water. Many a trade or enterprise, now handicapped by cost of motive power, would receive by this means a greater impetus than it would derive in any other direction: and the results might be the conferring of a substantial boon, not alone on the persons concerned, but on the country at large, and especially so from the point of view of removing industries from urban into suburban districts. Here, again, however, the Socialist idea of keeping alike the 'public services' and the means of remunerative employment in the hands of the municipalities has prevailed; and, while economy would suggest that electric power should be distributed over a wide area from a common centre, the general tendency of local governing bodies has been either zealously to acquire powers and then not use them, or else to want to set up a separate plant for each particular district. Elsewhere the enterprise of the private trader has been restrained, because he has known that as soon as the local authorities heard of his plan they would probably start a scheme of their own, while, even if they did not want to do so at once, there could be no certainty as to their future policy.

As far as London is concerned, a Select Committee of the House of Commons ${ }^{1}$ has made plain the course which the central municipality (the London County Council) must pursue in dealing with the question of the supply of electric power in bulk. The struggle

1 On the London County Council (Electric Supply) Bill, 1906. 


\section{THE DANGERS OF MUNICIPAL TRADING}

between private enterprise and municipal traders to possess the London area for the supply of electric power began in I905, when the Bill of the Administrative County of London Electric Power Company, round which the conflict centred, first failed to pass the House of Commons at the formal stage of third reading in order to become law, after surviving the struggle through Committee. It was the victim of grandmotherly methods of procedure only, not exclusively of municipal hostility, for the promoters succeeded in overcoming the objections of quite a number of London local authorities, and obtained agreements with them. The London County Council, however, and other local authorities fought tooth and nail against the Bill. The prorogation of Parliament nearing, it was a fight against time all along the line, and the opposition to it prevailed only to the extent that the Bill happened to emerge victorious from the squabbles with which it was beset in committee just as the House of Commons was winding up the session. No less a sum than $£ I 50,000$ was said by those acquainted with the inside history of the Bill to have been wasted in Parliamentary costs, as well as an enormous amount of time. This gigantic scheme for providing cheap electric power to manufacturers who badly need it, of far-reaching importance and possibilities, would have greatly stimulated industry, and have afforded employment to large numbers of men.

Professor Silvanus Thompson, in a letter to the newspapers at the time, dealing with the unscientific and 
uneconomic arguments urged against the Bill by the municipalities, said: 'It is something truly pitiful to see little municipal councils, which could not possibly supply to manufacturers in their area electric power at a price below $I d$. per unit, offering parliamentary opposition to a great industrial enterprise capable of doing so. London municipal undertakings, like Hampstead or Lewisham, cannot go below this price without charging extravagantly high prices to the ratepayers for their lighting, or else making a loss. Yet they oppose the Bill that would benefit the consumers in their own districts.' What a London borough council cannot supply at $I d$. per unit he showed was being supplied at considerably less on the Continent and in the United States and Canada; whilst, 'here in England the time of Parliament has been wasted over a wretched wrangle whether an enterprising body of industrial persons, the chief of whom have already made an eminent success of the electric-power supply in Newcastle, shall be permitted to offer to the London borough councils an electric-power supply cheaper than they themselves can make it.' Professor Thompson went to the root of the matter in saying that it was impossible for a great industrial supply of electricity for power purposes to be carried out-as it must be carried out for reasons of national prosperity-if every parish, vestry, borough council, or county council is to step in and claim the sole right of electric production and supply within its own area. The creation of great enterprises, Professor Thompson concluded, was a 
matter far too important for the industrial world to be baulked by the dog-in-the-manger policy of bodies who are themselves unable to create that which they oppose.

The General Election which took place at the beginning of I906 completely altered the political complexion of Parliament. The electorate returned a party strongly committed to Socialistic and municipal-ownership legislation; hence it was plain that if a private electricpower Bill had failed to pass the old House of Commons by accident, it would receive a similar fate in the present one by design. One of the first acts of the new Parliament was to reject by a sweeping majority a private electric-power Bill which contemplated supplying power in bulk in the London area at $\frac{1}{4} d$. per unit from a coal-field location near St Neots, about sixty miles from London. It received this fate on the excuse that the promoters would not consent to its being considered (they believed unfairly) by a hybrid committee formed to examine all power Bills for London. Among these Bills the Administrative County of London Company agreed to include their scheme. But in conflict with them all was the scheme of the London County Council, who had been rudely awakened by the promotion of these big projects into proposing an alternative one. The discovery that the Metropolis provided a wide field for the supply of cheap electric power in bulk by private enterprise, similar to the Tyneside district supplied by the Newcastle company, moved the London County Council to the decision that at all 
costs the Metropolis must not be similarly well served. In the Metropolis, with a population of six millions, the present output of the existing electric lighting and supply companies is 253 million units per annum, or only 42 units per head. Compare this with New York, with a less population by a third (about four millions), which has a total output of $97 \mathrm{I}$ million units per annum, or 282 units per head of population. The requirements of London for electric power and traction, apart from current for heating, lighting, and for County Council tramways, have been estimated at $\mathrm{r}, 800$ million units per annum, which necessitates the installing of a plant that can deal with a maximum load of 430,000 kilowatts. The London County Council, in the scheme they proposed, contemplated a plant with a capacity of only 60,000 kilowatts. Even the friendly Select Committee, before which the Bill came for consideration, was driven to the conclusion that this was a most inadequate way of meeting the case, and threw out the Bill. Standing alone, this failure of the Council to satisfy Parliament of its fitness to provide London with the electric power it needs might be deemed an accident. But it came after similar fruitless attempts made in I905, and also in I903 and I902. Whatever may be the potential qualifications of the London County Council to take on its shoulders a task which belongs strictly to engineering science, the fact that it does not know how to set about it shows conclusively that the question is quite outside its domain. The Select Committee, however, whose members reflected 
the strong Municipal-Trading sympathies of the present Parliament, did not take this view. It declared that the authority for the supply of electric light and power in bulk should be the County Council.

The terms of the Committee's Report at least clear the air as to the part the municipalities must take in this pressing public matter. The Council in their Bill only sought voluntary powers to supply electrical energy, which they could carry out or not, as they chose, their object not being to render 'superior public service,' but to prevent private companies coming on the scene ready and willing to perform that duty. The Committee said that the power of the Council must be obligatory; it would not agree to the continued pursuit of a dog-in-the-manger policy which merely meant that private enterprise was prevented from selling a commodity to the full extent of the vast demand for it, whilst the Council only contemplated supplying it according to caprice, in driblets, or not at all. 'The paramount authority you shall be', the Committee said to the Council; 'but you must properly fulfil your functions. The matter is too important to be trifled with. You must bring in a better Bill, on comprehensive lines, and perform adequate public service. If you do not, private enterprise will be invited to propose an alternative scheme.' The Daily Chronicle, an avowed ownership organ, urged the Council to act at once on the advice of the Committee, 'as this will be their last chance.' But this journal warned the Council that if they rely on their own officers, who are 
fully occupied with their daily duties, to prepare what will be the largest electric-power scheme in the world, the Council will court failure.

Some hope is entertained that the newly-elected body will see the wisdom of abandoning the attempt of their predecessors to construct, control, and absorb the electricity supply. Already there are several alternative schemes before Parliament, and it seems probable that, while the control will, to some extent, be left in the hands of the Council, the work will be carried out by private contract, and that private electricity-supply companies will compete for the maintenance of the service and for the distribution of electrical energy to the respective users. Municipal monopoly of electricitysupply within the Metropolis ought, in fact, to be regarded as condemned. Open tenders and free competition among traders was the plea at the last election, and it should be allowed to take shape and characterize such reforms as may now be introduced. The end of the controversy at this writing seems near, and the proposal made by the Parliamentary Committee has every appearance of being sound and sensible. The Bill will probably be modified, so that private enterprise will be allowed to generate and manage the supply of electricity within the area covered by the Bill, and the Council will retain ultimate control. Even those favouring municipal trading will hardly regret that the expenditure of some twenty millions sterling out of the rates has thus been avoided. 


\section{CHAPTER XIV}

FAILURE OF TELEPHONES UNDER STATE OR MUNICIPAL MANAGEMENT

$\mathrm{HE}$ backward condition of the telephone industry
of England has been a hindrance to commerce, a source of annoyance to private communication, the subject of investigation by Parliament, and a topic of endless discussion and controversy by those interested on both sides of the problem of Municipal Trading. The advocates of Municipal Trading and of State appropriation of public services have vociferously maintained that the cause of this lack of enterprise may be traced to the fact that until recent years the telephone service was wholly in the hands of a private company. On the other hand, the friends of the company declare, with equal force and a strong array of facts, that the real cause of the trouble comes from the unreasonable interference and unjust demands of the British Government, which have made it impossible for private capital and enterprise to push ahead, apply the latest inventions, and increase the service by reduction of price, and extension alike of public and private exchanges. A glance at the history of the telephone in England strongly indi- 
cates that the Government has played a fast and loose game with those who have undertaken to establish it, with the result that its progress has been retarded, because the company never knew quite where it stood. Officialdom has done what it could to retard invention and to stifle enterprise. But as soon as the telephone became finally established between such large centres of population as Liverpool and Manchester, and began to make inroads into the postal telegraph revenues, the Post Office Department became alarmed and intervened. It was decreed subsequently by the courts that the telephone was a telegraph, and that telephones worked for public benefit came under the Telegraph Act of I869, and that, therefore, the Government had a monopoly of them.

This was naturally a severe blow to the National Telephone Company, and one calculated seriously to impede its enterprise. As the Government of the day was not prepared, or not sufficiently sure of the financial success of the telephone system, to take it over bodily, as it had done the telegraphs, it licensed the National Telephone Company to work under the Telegraph Act at a ten per cent. royalty on the gross receipts. The licenses were restricted because they were contingent upon the consent of local authorities, who could place obstacles in the way, and prevent the laying of wires, and otherwise obstruct the system's installation. For some years the telephone company seemed to have struggled along, having little faith in the final outcome, until in 1892 the Government came to a general arrangement in reference 
to the telephone business of the country. The general outline of the arrangement by which the British Government in 1892 took over part of the telephone business of the country was that the trunk wires which connect large towns should be worked by the Postmaster-General, and that business inside towns, which in England is generally called 'exchange business', should be left in the hands of the company. This dual arrangement had its disadvantages, and, as those who understand the business will realize, its inconveniences; but the telephone company could do nothing but proceed along the line mapped out by the Government. Having no control over the entire system, and being more or less hampered by municipalities in the laying of wires, and, moreover, being compelled to pay a large royalty to the Government, the inducement to invest additional capital was not great. The Government and the company seemed to have worked together fairly well, giving an indifferent service for a rather high price, until the municipal traders, looking around for new fields to conquer, took the matter up. The Telegraph Act of 1899 gave the municipalities the right to establish and work local systems within their own area in competition, not with the Government trunk lines, but with the telephone company. As everybody knows, the telephone service is not one which lends itself to competition, because it is obviously inconvenient for a telephone subscriber to find that people with whom he wishes to speak are not on his system, but on another. It did not take long for the Government to discover that the entrance of the 
municipalities into the telephone business was a mistake. The dual arrangement became a triple one: there were three agencies-Government, municipal, and company - engaged in managing a public service, the proper and efficient service of which made it absolutely necessary that it should be centralized, and that it should be conducted by a single administration. Such competition only made confusion worse confounded. The Government awoke to the fact that the municipalities were interfering with the exploitation of a field which belonged to the State, the telephone having been declared a Government monopoly as above stated, to be handed over, lock, stock, and barrel, to the Post Office in IgII. The agreement made with the National Telephone Company, by which the Government will take over the latter's system in that year, removed many causes of differences between the Government and the company, who now work more in unison; but the establishment of municipal systems opened out the prospect to the Government authorities that in place of private competitors they were to have municipal competitors. The actual position was not a serious one; it rather called for consideration in view of what it threatened to become. In fact, only thirteen towns availed themselves of the Act of I899, and applied for telephone franchises; of these but six exercised their franchises, and one (Tunbridge Wells) early sold out to the company, glad to be relieved of the ill-starred venture. Four or five years' experience of municipal telephones, in short, proved that they would never succeed as com- 
petitors either of State or private business, but that they would only exist as an obstacle to telephone progress. In I905 the Post Office decided that no more telephone franchises to municipalities would be granted, and the House of Commons confirmed the change of policy by a large majority. Mr John Burns, a great champion of the municipalities, said in that chamber at the time that local authorities had not established their claim to compete with the company or with the Post Office, or with both, between then and IgII. Further, he regarded telephones as a national, and not a local service. The five municipalities-Brighton, Glasgow, Hull, Swansea, and Portsmouth-have all along the line been unable to hold their own with the National Telephone Company, and in several places have conflicted with the Post Office services. They have been unable to secure their fair share of new businesses which offered day by day. The systems have cost a great deal more than the original estimates ; much of the plant laid down is of an inferior character ; whilst the finances of all the municipal systems are in about as unsound a condition as they can be. $\mathrm{Mr}$ Herbert Laws Webb ${ }^{1}$ has pointed out that they fixed on a rate for a single class of service, regardless of the fact that there are various classes of services, regardless of engineering problems, regardless of the size and character of the area to be covered, regardless of the development to be aimed at, and regardless of the hundred and one conditions that have their bearing

1 The Times, September 5, 1905. 
on the subject, and they attempted to subject a vast and complicated industry to an arbitrary rule arrived at by pure guesswork. It is no wonder, therefore, that the Government, having given the local authorities their opportunity, should have cut short further fatuous experiments in municipal telephony on finding that their continuance only means conflict with the State system, and public inconvenience. The wisdom of all the other British municipalities, who preferred to leave municipal telephony alone, is plain enough from the foregoing. Such abstention may well count for righteousness in view of the fact that the five towns which were imprudently caught with the cry of 'municipal telephony' have been nursing weaklings for their pains. The towns which forebore may congratulate themselves on having one folly the less.

Tunbridge Wells, which was the first to avail itself of the provisions of the Act of I899 for the establishment of municipal telephony, soon repented of its foolhardiness, as I have said, and sold the undertaking to the National Telephone Company in I902. The capital expenditure on the system was $£ 28,000$, and the municipal officials endeavoured to show that the first year's working resulted in a small profit. Though the venture thus appeared to be self-supporting (to what extent it was secretly aided by the taxes did not, of course, transpire), Tunbridge Wells citizens quickly showed that they were not enamoured of the enterprise, especially when the same municipal officials, in a later report, estimated that the undertaking would produce a future 
annual loss of $£$ Ig. The matter was made an issue at the election of I902, when several supporters of the telephone undertaking were defeated, including the chairman of the Telephone Committee. The result was that the proposal to sell was carried at a meeting of the Council by nineteen votes to eight. The company took over all the liabilities of the undertaking, and, for every unlimited service-subscriber, it pays to the municipality 3s. annually, which may produce an annual income of $£$ Ioo. The municipality were then quit of an enterprise they were unable to manage, received back every penny of capital expenditure they incurred, and secured a small revenue from the company in aid of taxation.

Glasgow obstinately held on to its telephone undertaking to the last; but the local council finally agreed to sell it to the Government-scorning an offer from the company at a higher price. Experts have condemned the Glasgow system as unsound, financially and technically. Established on the assumption that the average capital cost per subscriber's line would be something less than $£ \mathrm{I}$, such cost has turned out to be over $£ 33$, or nearly double. Its competitive force may be judged from the fact that, whilst in I904 the additions to the stations numbered 957 , of which more than 600 were extension and party-line stations, and only 305 direct subscribers and public telephone lines, the gain made by the National Telephone Company's Glagsow system amounted to over 6,000 stations of all classes. The competition of the municipal system with the company had for some time since come to a stand- 
still, and so completely was it overshadowed and enveloped by the system of its more progressive and alert rival that Glasgow citizens began to look upon it merely as a stand-by. Capital expenditure to the amount of $£ 380,000$ was spent on the undertaking: according to the estimates it ought not to have cost more than $£ 200,000$. Gross receipts were estimated at 28 per cent. of the capital invested, so that the sum spent $(£ 380,000)$ should have produced an annual gross revenue of over $£$ I00,000. In I905 the gross revenue was only $£ 55,226$, or I5 per cent. on the capital. The whole scheme, therefore, wandered from the original plan, having had $£$ r6o,00o in capital outlay spent on it more than it ought to have had, and yielding in revenue $£ 45,000$ less than it ought to have earned. The system has passed into the hands of the Government for the generous price of $£ 305,000$ for what was really a derelict; so that, compared with the original capital outlay $(£ 380,000)$, brought down to $£ 290,000$ by payments to sinking fund, and a contribution out of the taxes, the capital loss, on the surface, does not appear to be very great. To sum up, it has been well said that ' Glasgow started in the telephone business with the confident hope of extinguishing the service of the National Company, and of establishing another municipal monopoly. It is a bright feather in the cap of private enterprise that a great and wealthy municipality, with all the local influence that a big trading municipality possesses, should have been so signally defeated in such a short time. That the Glasgow 
municipality would sell their telephone system if they saw the least hope of working it at a profit, or of maintaining their ground in the competition, is not to be imagined for a moment. The sale means that the corporation realize that the position is hopeless, and are glad of the opportunity of retiring without the honours of war.'

Brighton's experience of municipal telephones is similar to that of Glasgow. It has been thoroughly outpaced by the National Telephone Company, whose system has considerably more than double the number of telephone stations served by the municipal undertaking. The latter's small circle of customers had steadily begun to diminish when the Government offered to take it over, so that there was nothing left but to follow the lead of Glasgow, and to sell the concern. The capital spent on the undertaking amounted at the close to $£ 52,7 \mathrm{I} 8$. The purchase price at first offered by the Government was $£ 4 I, 200$, based on expert valuation of the plant, but this was forced up to $£ 49,000$, so that the municipality comes out of the transaction little the worse. As usual, the cost of laying out and working of the undertaking overshot the estimate. In the latter provision was made for 2,080 subscribers and public-station lines at a total cost, inclusive of 600 partially completed spare lines, of $£ 43,280$. But the actual capital outlay, as stated, was $£ 52,7 \mathrm{I} 8$, and that provided only I,5I4 subscribers and public lines. Based on the estimate, the municipal

1 Electrical Review, July I3, 1906, from which the figures quoted were taken. 
system should have been built for $£ 37,000$. The system also failed to get more than three-fourths of the estimated number of subscribers after three years' endeavour. The net surplus for the financial year to March 3I, I905, was given as $£ 4$ I3, but nothing was placed to depreciation. Putting this at the low figure of $2 \frac{1}{2}$ per cent. on the capital sunk in the undertaking $(£ 52,7 \mathrm{I} 8)$, there appears a debit item of $£ I, 300$ omitted, which swamps the profit and leaves a deficit. On the first six months' working there was a loss of $£$ I,800. A sidelight on the conduct of the concern was shown at a Local Government Board inquiry made in May of rgo5 to sanction a loan of $£ 7,545$ for telephone extensions. It transpired that over $£ 5,000$ of the sum had already been spent. This, it may be remarked, is not surprising, as it is not unusual for sanction to be asked of the Local Government Board for the raising of loans after the event. The situation naturally becomes Gilbertian if it happens that the Government inspector refuses to allow the borrowing of a sum of money that has already been obtained and sunk and lost in some water-logged concern. It is true the evidence put before him usually reveals the state of affairs, so that the procedure of sanctioning becomes a solemn farce.

Hull started telephones in January of 1904, and the first year's working, on a capital expenditure of $£ 30,370$ yielded a deficit of $£ 73$. A renewal of the license beyond I9II was refused by the Postmaster-General, who suggested consolidation with the National Telephone Company, or, as an alternative, an offer to sell 
the telephone service would be considered. Like Glasgow, Hull municipality will not hear of its pet telephone system becoming absorbed by the company. The second year's working (I905-06) produced a sum of $£ 2,863$ after expenses had been deducted from receipts. This sum, according to the Eastern Morning News of May 2, I906, has been made to appear a 'profit.' Interest and other charges, however, reduce the ' profit' to $£ 476$, and if from this sum the deficit on the previous year $(£ 73)$ be deducted, the balance is $£ 4 \mathrm{I}$. But, as in the case of Brighton, nothing has been put aside for depreciation, and if this be allowed for at even $2 \frac{1}{2}$ per cent. on the present capital outlay $(£ 45,000)$ - the journal named puts it at 5 per cent.-it will be seen how misleading is the bare assertion that a profit of nearly $£ 3,000$ was made on the municipal telephones.

The same observation may be applied to the 'profits' of the remaining systems-Swansea and Portsmouth. In the case of the latter, the Electrical Reviere ${ }^{1}$ pointed out that expert opinion showed that as much as ro per cent. should be written off for depreciation, but the local Council wrote off nothing. The sinking fund is often made a substitute for depreciation, and Portsmouth, during the four years' working of its telephone system, has managed to place $£ 2,538$ to that fund, or just under 57 per cent. on the total capital outlay of $£ 44,532$. 'An alleged profit', remarks this journal, ' is shown for the year I905-06 of $£ I, 849$; but if depreciation and maintenance costs were properly charged and

1 June 29, 1906. 
interest and sinking fund paid on the full capital, the present annual loss would probably work out at between $£ 4$,000 and $£ 5$,000.'

The due disappearance of the municipal systems, however, does not improve matters for the taxpayers, when it is remembered that the State is the eventual successor to the whole telephone system. Centralization of management will certainly be effected by the transfer, and so the control of the telephones will not be further impeded by the appearance of any more small local opposition systems with their connexions confined within the municipal areas, as would be the case were the company continuing its existence. Hence, in the circumstances, Government expropriation is the lesser of two evils. It is the wind-up of a long-pursued policy of vacillation and indecision expressed by all manners of hindrances placed in the path of the company which have prevented its development and full efficiency. But the action at least appears to have been precipitated by the recognition that if company operation, - obstructed by State interference, was bad for the telephone public, ineffective municipal opposition to the company, which also threatened to be a thorn in the side of the State when it became telephone owner, was worse. The failure of municipal telephones in Great Britain, therefore, appears to have hastened the change, and the company will be extinguished earlier than it otherwise would be, in order that the blundering municipal telephone policy should come to an end.

Economically considered, however, if the State I6-2 


\section{THE DANGERS OF MUNICIPAL TRADING}

control of the telegraphs be taken as a criterion, the transfer only means the removal of the telephones from becoming a possible burden on municipal taxation to an almost certain burden on Imperial taxation. The taxpayers stand to gain nothing, but rather to lose, by the change. Since the State took over the telegraphs in Great Britain, extraordinary annual deficits-due, perhaps, in a measure, as I have said, to a sixpenny rate, as the result of political manipulation-have been the rule, and are on the increase. To the greater popularity of the telephones has also been ascribed some of this loss; hence their acquisition would only remove the competition if it meant limitation or discontinuance of telephonic communication. That, of course, is not intended; rather, greater efficiency and development, to the extent to which a forward commercial policy is a practical proposition in Government hands. But should the Government concern itself about seeking to promote the telegraphs to a profitable undertaking, they will have a powerful rival in their possession, whose operation they have only to curtail and weaken in order that greater public use should be made of the telegraphs. If they give both systems equal play, they are merely competing with themselves. But whether they neglect or improve the telephone service, the prospect is that Government working will not contribute as profit to the Exchequer anything like the amounts corresponding to the royalties the telephone company annually pay to the State. The losses on the telegraphs project too conspicuously for them not 
to be closely considered. As the telephone has been legally classified with the telegraph, and is, therefore, a Government monopoly, the figures may fairly be taken as indicating that the telephones, under State control, will cease to be profitable. When the telegraphs were taken over from the companies by the Government in 1870 , the profit in that year on company working was $£ 338,500$. In fairness to the present telegraph organization, it is right, however, to add that some of the private companies which the State system replaced were in many respects corrupt, that their charges were monopolist charges, and that the service was inadequate. The following figures show what has happened since (all the years are not given, but those omitted tell the same story) :

Annual Deficits on State Operation of the British Telegraph System.

\begin{tabular}{|c|c|c|c|c|c|}
\hline & & & & & $\begin{array}{l}\text { rcentage of Expen- } \\
\text { diture to Gross }\end{array}$ \\
\hline & & & & Deficit. & $\begin{array}{c}\text { diturure to Gross } \\
\text { Receipts. }\end{array}$ \\
\hline $1883-84$ & .. & .. & . & $£ 19,697$ & IOI·IO \\
\hline I $884-85$ & .. & . & . & 36,370 & $102 \cdot 03$ \\
\hline $1885-86$ & .. & .. & .. & 45,137 & $102 \cdot 52$ \\
\hline I 886-87 & .. & .. & .. & 125,437 & $107 \cdot 70$ \\
\hline I900-OI & . & . & . & 337,641 & $109 \cdot 76$ \\
\hline $1901-02$ & .. & .. & .. & $65 \mathrm{I}, 88 \mathrm{I}$ & I I $8 \cdot 26$ \\
\hline $1902-03$ & .. & .. & .. & $60 \mathrm{I}, 7 \mathrm{II}$ & $I I 6 \cdot I 6$ \\
\hline I903-04 & . & .. & .. & 957,783 & $125 \cdot 64$ \\
\hline $1904-05$ & .. & .. & .. & $\mathrm{I}, \mathrm{I} 9 \mathrm{I}, \mathrm{I} 26$ & $125^{\circ} 00$ \\
\hline
\end{tabular}

In contrast to these figures, it is profitable to show the annual contribution which the telephone company has paid into the State coffers by way of royalties. 


\section{THE DANGERS OF MUNICIPAL TRADING}

Up to September 30, I900, the total amount so paid by the present company and its predecessors has been $£ I, 08 I, 490$. Since I896, when the Government took over the trunk lines, the sums paid annually have expanded year by year as follows :

Annual Royalties paid by Telephone Company to the State.

\begin{tabular}{|c|c|c|c|c|}
\hline $896 \quad \ldots$ & $£ 79,266$ & I9OI & .. & $\cdots £_{146,578}$ \\
\hline . & 89,238 & 1902 & .. & I 54,407 \\
\hline & 104,029 & 1903 & .. & 168,248 \\
\hline 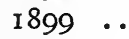 & 123,061 & 1904 & .. & I 85,937 \\
\hline & 140,074 & 1905 & .. & 206,055 \\
\hline
\end{tabular}

It should be pointed out that the British Post-Office, in addition to working the trunk lines, have already gained some experience in the operation of urban areas, by the establishment of a Government telephone system in London in I902. Each year since has shown a deficit. Here is the result of the working for I904-05 :

Balance, after deducting expenditure from receipts, available toward meeting depreciation, interest on capital, etc. .. $£ 93,298$ Estimated deficit $\ldots$ 21,129

$$
\overline{£ 114,427}
$$

Estimated depreciation

Interest on capital expenditure $\quad \therefore \quad 57,780$

Thus, whilst the taxpayers benefited in 1905 by the contribution of $£ 206,055$ made by the National Telephone Company to the Exchequer, they lost $£ 2 I, I 29$ on 
the Government service in London. It is right to state, however, that the financial year I905-06 shows a balance, after meeting depreciation and interest. This is the first time such a result has been achieved, but as the revenue on previous years has been insufficient to meet all charges on the service, a considerable deficiency remains to be met out of the balances in future years. But the surplus of I905-06 stands out as an isolated figure, and Government working hardly assures that future years will yield a similar result. On the other hand, in regard to the telegraph service, it must be remembered that considerable expenditure has in recent years been necessary to extend the vast system of subterranean cables throughout the country, and that the service is the finest in the world. Also, it should be remarked that the United States telegraph system, as distinct from the United States telephone system, is more subject to interruption, even on comparatively short lines, like Washington-New York, than is the British inland system. Again, the British telephone system, as a State concern, is of recent growth, and I have no desire to prejudge the results of taking it over.

Conceding all this, one has only to glance at European countries to prove the soundness of the proposition that State or municipal working fails as applied to telephones. Mr U. N. Bethell, in a paper read at the National Convention upon Municipal Operation and Public Franchises which met at the New York Reform Club in I903, submitted ample testimony to support the contention. In Belgium, France, Switzerland, Germany, Austria, and 
Hungary, he tells us, the central government operates the industry. In Holland the State, as in Great Britain, operates the trunk lines; whilst in the two principal cities, Amsterdam and Rotterdam, the municipalities operate the local systems. In Denmark and Norway, private enterprise under Government control operates the industry. In Sweden the State does so, except that in Stockholm and its vicinity a private company since I89o has been in active competition with the State. It is worth while to summarize Mr Bethell's investigations. In France, the telephone is mainly confined to Paris, where the service is generally inefficient and the plant behind the times. The service outside that city has only a small development. The defects of the French system are purely governmental, and are not to be attributed to incapacity on the part of the technical staff. Political influences interfere with the management, which is unable to enforce discipline, and incompetent operatives-who would not be tolerated under private operation-have to be borne with. The accounts are not published separately, so that the probable losses are not known.

Belgium has not succeeded in furnishing an efficient service at reasonable rates. As in France, the discipline is extremely lax, and the service, therefore, inferior. Neither Brussels nor Antwerp is sufficiently served, the number of telephones in the first-named city, with a population of 560,000 , being about one-fifth of the number in Manhattan and the Bronx alone, whilst Antwerp, with its 280,000 people, had only 3,666 . The 
telephone accounts are not disclosed separately, so that, again like the French system, how the industry fares financially is kept dark. "With such small systems as they have in Brussels and Antwerp ', remarks Mr Bethell, ' confined in each case to the heart of the city, and consequently operated under the most economical condition, with the high rates they obtain, with the low wages they pay, with the freedom they have from taxation, from charges for rights of way, and for the use of public buildings, it would seem strange indeed if they did not show a profit. But the failure to meet other tests is sufficiently striking to make the question of profits quite immaterial.'

Switzerland shows a similar experience. The service is inferior, antiquated ground circuits are still in use, and the wages paid to all classes of employés are extremely low. The service is so little used by the public generally that the revenues fall short of the expenses year after year, despite cheap labour and high rates to subscribers. The unfavourable conditions are wholly due to political interferences, the ignoring of recommendations urged by the technical staff, whose personal efficiency is hidebound, so that the adoption of ordinary business principles is impossible. According to The Statesman's Year-Book for I906, the deficit in r904 on telegraphs and telephones amounted to $£ 27,323$.

In Holland, the State has allowed the municipalities of Amsterdam and Rotterdam to carry on the local systems under a limited charter. Though strongly bound together by social and commercial ties, which 
demand co-ordination and uniformity of the methods employed, the features and general conduct of the telephone business in the two places are dissimilar. The failure to co-operate in the management of industries where local needs demand working agreements between municipalities, such as those operating between New York and neighbouring towns, is undoubtedly a fatal objection to the acceptance of the public-ownership doctrine. But other considerations enter beyond the lack of harmony which municipalities show in their dealings with one another, or, rather, in keeping one another at arm's length. Mr Bethell puts the case succinctly: "To be efficient and satisfactory to the public the telephone systems within such an urban centre, no matter how many municipalities or cities it may contain, should work harmoniously, and this requires that they should be under one management. A municipality must confine its operations to its own territory. If it goes beyond that it uses the funds of its citizens for the benefit of others. When it allies itself with other municipalities there must be divided responsibilities and divided powers. In such an event satisfactory ultimate results cannot be expected.'

Nor have satisfactory results been obtained in the working of the self-contained systems of these two Dutch cities within their own boundaries. At the beginning of I903, Amsterdam, with a population of 525,000 , had only 5,903 telephones in use ; whilst Boston, with about the same population, had then at least four times that number; Manchester (population 543,390), 
over ro,000; and Copenhagen (population 3i2,859), over I7,500 - the telephones in the latter cities being under private operation. Rotterdam (population 332,000), with 4,I85 municipal telephones, compares badly with Cincinnati, which, though of less population, has I4,3I2 telephones under private ownership. Amsterdam municipality, with an inadequate and inferior service, unenterprising and little used, a high tariff and irrational and unfair rates, succeeded in stifling the private system by a limited franchise and a tax of $2 \mathrm{I}$ per cent. on the gross receipts. Mr Bethell shows that the franchise tax paid to the city in I894 amounted to $£ 3,425$, the company having then less than I,700 stations. In I902, with more than 5,000 stations, the municipal telephone system paid into the commercial treasury a sum of £4.000. Had the company by $I_{902}$ been allowed to develop its system to the number of municipal stations in that year, or three times the number of private stations in I894, its contribution to the city funds made in the latter year would have increased threefold by I902, or $£$ Io,272; per contra, the common treasury only received $£ 4,000$ under municipal management of the telephones.

A word remains to be said of Greece. From a report of the United States Consul, it appears that there is a growing discontent there with existing telephone conditions. He says that the appliances in use are inadequate, and the service is unsatisfactory. For this reason the telephones are but poorly patronized, and it is stated that they are an unprofitable investment to 
the Government which controls them. Things appear to have reached the pass when the Government would grant a concesson to some trustworthy private company prepared to instal up-to-date, effective telephones. The people are said to be ready for such a telephone service, and would support it with their patronage. The value of the present plant is put at the insignificant figure of $£ 25,000$, and there are at present only about 600 telephones in operation in Athens, Piræus, Phaleron, Kephisia, and Decelia, and one long-distance wire connecting Athens and Patras. The Consul considers that there is a profitable opening for capital, as there appears to be a very general desire on the part of the people for an improved service. And for that they turn from the Government and look to private enterprise to supply it.

In striking contrast to the unsatisfactory state of things in European cities where the telephones are in State or municipal hands is their superior efficiency in the Scandinavian countries under private ownership. Mention has already been made of Copenhagen. There the development of the telephone by proper service and reasonable rates is wholly due to intelligent and energetic private enterprise. In Stockholm, where the State and the company are in active competition, so keen as to make the rates even too cheap for Swedish manufactures, the private system in I903 numbered 32,563 telephones in a population of 300,624 ; these figures bring Stockholm in line with American cities of relatively the same class which are well served with telephones. 
The table on p. 254 shows at a glance how badly off for telephone service are European cities where the undertaking is State or municipally managed, compared with cities where private operation obtains (the figures generally refer to the years I902 and I903).

The people of the United States so far have had no experience of State or municipal telephones. Since the expiration of the original patents, competition has not only greatly increased the efficiency and reduced the cost, but in some States, where the laws have effectually regulated these monopolies, there has been established a service and low rates it would be difficult to excel. Immunity from State and municipal interference undoubtedly accounts for the fact that the United States, with its population of $78,000,000$ in $\mathrm{rg02}$, had $3,400,000$ telephones, whilst the United Kingdom, where the State and municipalities have been a constant drag on the National Telephone Company, possessed only 365, I9 8 telephones for a population of 42,000,000. The contrast is further accentuated by comparing the capital invested in telephones in the two countries: United States, $£ 76,906,8 \mathrm{I} 3$; United Kingdom, about $£ \mathrm{I}_{5}, 000,000$. Whilst London has only 18 telephones per 1,000 inhabitants, or one telephone per 55, California has a telephone for every $\mathrm{I}_{4}$ inhabitants, Ohio one for every I9, San Francisco one for every 9, New Orleans one for every 4I, and New York one for every 39 inhabitants. The extraordinary strides the telephone has made in the United States through individual enterprise having 


\section{THE DANGERS OF MUNICIPAL TRADING}

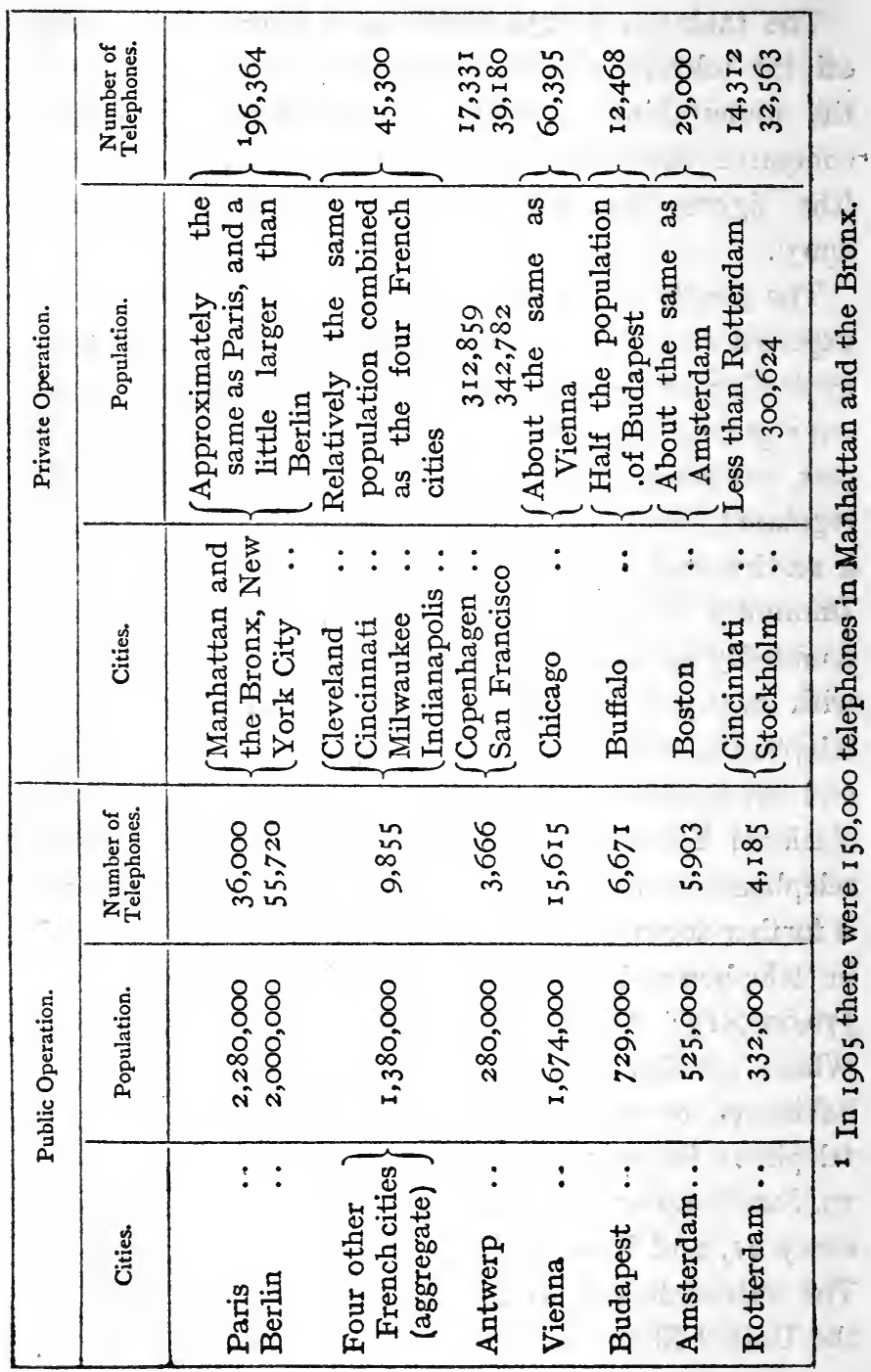


been given free play, can be seen from this table published in I906:

Number of telephones in the United States .. Population

$$
\text { .. } 50,155,783
$$

In 1880.

54,319
Ratio to PopulationPersons per Telephone. 923 34

Systematic improvements in equipment and frequent scrapping of old plant (a practice generally unknown in State and municipal management of telephones in Europe) have largely operated to cause the great and continuous development of telephones in America. The following excerpt from the report of the Merchants' Association of New York, which in I905 inquired into the telephone system of that city, equally applies to other American centres: 'In the New York telephone system improvements and changes have succeeded one another at close intervals during the entire period in which the business of exchange telephone service has existed. During the sixteen years which the committee's investigation covers, the plant had been practically rebuilt three times. At various times radical improvements have been made in cables and in switchboard systems, which have involved the abandonment of plant by no means unserviceable, because of its physical condition and its replacement by plant of an improved character. Some of the central stations have been rebuilt three times within a little over ten years.'

The broad gulf which exists between the telephone system of America and that which it occupies in the 
United Kingdom and other European countries consists solely in the fact that in America no restrictions have been placed on its development, whilst in Europe the telephone system has never been treated as a legitimate business enterprise, and has never had a fair field. Though of late years improvements have been made in the British system, nothing like a general and complete re-equipment, bringing the service to a uniform high efficiency, such as long ago was accomplished in America, has been undertaken. There is a larger field for telephone enterprise in London than anywhere else in the world, and to telephone it according to its needs, or at the same rate of development that is taking place in New York, Mr H. L. Webb ${ }^{1}$ estimates would require an annual increase of stations of about 75,000. At present the increase is only 18,000 stations annually. ' Not until the present unbusinesslike tariff is modified, and the telephone needs of London are studied on a whole, will any sound progress be made toward a real solution of the problem. To distribute 500,000 telephones over the 640 square miles of London will require

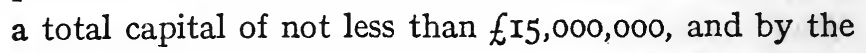
time that 500,000 telephones are in service, that number will only seem a moderate development for London.'2 How the Government, when it takes complete charge of the whole telephone system in I9II, will handle the problem is a question not easily answered. But it is certain that had the National Telephone Company been

1 The Times Engineering Supplement, April 25, 1906.

2 Ibid. 
left alone in the past, and had not the shadow of State expropriation hovering over it to-day, telephonic development in Great Britain would have proceeded very much along the lines followed in the United States. Even now, with a long leeway to make up, considerable progress could be effected if a longer life was assured to the company.

However, enough has been said, I think, to prove conclusively that State and municipal monopoly, and restrictions of telephonic progress in Europe, and especially in Great Britain, ought to be carefully noted by all wise citizens, and, further, that the unsatisfactory conditions should not be allowed to be perpetuated. So far from the public conduct of services in Europe affording an example to be followed, the march of progress in all directions should be recognized as being the result of individual effort. The European method of State or municipal acquisition of public services is to be studied only as an economic disease, the existence of which is of value as pointing the way to the necessity of taking preventive measures; otherwise the epidemic may develop, and by devitalizing the activities of the centres of industry, reduce individual effort to a farce, and citizenship to sheepish acquiescence. 


\section{CHAPTER XV}

\section{MUNICIPAL HOUSING}

$\mathrm{T}$ adding to their many onerous duties by becoming 1 house-builders and house-owners on a large scale, British municipalities cannot justify their action on the plea that they are supplying a 'long-felt want' of the working classes, as may conceivably be advanced by their providing baths, wash-houses, parks, open spaces, and the like. Private enterprise, either in the form of companies or individuals with defined commercial objects, or semi-philanthropic bodies content with a small return, were unostentatiously doing the same thing very well before municipal housing was thought of. The crying need of the poor for cheap and properly built houses or tenements particularly appealed to private benevolence. Directors of great housing trusts and companies in London, for example, have given their services gratuitously, and rents have been charged at so low a figure that the housing undertaking was little more than self-supporting. The Peabody Donation Trust, the Guinness Trust, and other industrial dwelling corporations in London, have kept pace with the demand for decent houses for the working classes; and in no 
degree have municipal experiments in the same direction succeeded in pointing to better results. A municipal model dwelling only differs from a private model dwelling because it is municipal. Municipal intervention in housing has removed no grievance, for none existed (clearing insanitary districts of slums is another question), and it has not provided better accommodation, for the competition between the housing companies was active enough to compel them to keep their cottages and model dwellings at a degree of comfort, cleanliness, and convenience which left no room for a municipality to attempt to improve upon. The charge made against private enterprise, that it has shown itself to be incompetent, or at least ineffective, in dealing with the housing problem is capable of easy disproof. $\mathrm{Mr}$ James Parsons ${ }^{1}$, who has made a study of the housing problem as it applies to London, has effectively disposed of the fallacy. In doing so he refers to the movement of the population of London within the decade I89II9or, as shown by the Census of the latter year, which pointed to an increase of population, within the Administrative County of London, of 308,000; whilst within the wider boundary of Greater London, which includes portions of the counties of Surrey, Kent, Essex, and Hertford, the increase was 639,000 , together an increase in population of 947,000 . In some of the central districts, however, there was a decline in populatiou amounting altogether to 67,000, which, in view of the increase for the whole of Greater London, pointed

1 Housing by Voluntary Enterprise. 
to a transference of population of that number from the central districts to the outskirts. Therefore, the total number of those for whom additional house-room was provided during the decade was I,0I4,000. $\mathrm{Mr}$ Parsons, for want of exact data, has had to conjecture the amount of capital sunk in providing this accommodation. But reckoning the family at 4.4 persons on an average, the number of families housed was 230,000 , and putting the capital expenditure at $£ 250$ per family, the sum expended exceeds $f_{557,000,000}$.

Let us glance at the operations of the London County Council in the same direction. According to published figures $^{1}$, the Housing Committee of that body, between I89o and March 3I, I906 (I6 years), have provided accommodation in the form of cubicles, cottages, or tenements in block dwellings for 33,847 persons, at a cost of $£ 2,305,43$ I. (No account is taken here of a large programme of housing schemes in course of development, which, including existing undertakings, brings the Council's housing estate to $£ 5,000,000$.) The actual capital expenditure works out at $£ 300$ per family, if all the dwellings were occupied to the number provided; but if the number of persons actually occupying municipal dwellings at the Census of I9or (which was then about a third less than the accommodation provided) be taken as a basis for arriving at the number of persons the London County Council at present house, the capital cost per family works out a third more-or $£ 400$ per family.

1 The Times, August 15, 1906. 
It is to be also noted that the estimated cost of sites is not the actual cost. Many sites built on by the Council have been written down from their commercial value to $n i l$, and subsidized besides—one site by $£$ I50,000, another nil, and subsidized by over $£ 3,600$, and a third by $€ \mathrm{r}, 000$. The Local Government Board has called attention to this deliberate manipulation of the Working-Class Dwellings Act, the object of which presumably is not to disclose the whole truth to the taxpayers. Another instance is the cost of a site (Brightlingsea Buildings) at Rotherhithe, which was $f^{12,000,}$ and for rehousing purposes the valuer put it down at $£ x, 000$. But the Housing Committee of the Council obtained the site for nothing. When the buildings were put up, the committee found that they would never yield a profit ; there would rather be a loss to the taxes of $£ 397$ a year. Instead of charging this loss against the buildings, they are subsidized year by year out of the capital account. Yet another case is that of the Beakesbourne Buildings at Rotherhithe. The Council gave the Housing Committee the site, valued at $£ 3,050$, for nothing, and in addition credited the housing account with a capital sum of $£ 6,335$ ' to preserve equilibrium!' A member of the Council, commenting on these instances ${ }^{1}$, said that if such a thing had been done by a limited company it would have been designated by another name. $\mathrm{He}$ also pointed out that the Council owns nearly 300 acres of vacant land, bought at building-land price, at an average of $£ 500$ an acre, which

1 Mr Edward Collins, the Times, August I5, 1906. 
entails interest (at $3 \frac{1}{2}$ per cent.) of about $£$ roo a week ; every five weeks the value of an acre of this land will be thus absorbed by interest.

Hence, if regard be given to the considerable underestimates of capital expenditure made on account of municipal housing for the working classes, the cost per family incurred by the Council must be double or treble $£ 400$. But apart from the cost, to provide housing for 33,847 persons in 16 years, if account be taken of the wage-earning population of London, is not a very striking performance. It becomes insignificant beside the enterprise of voluntary persons, who in ten years provided house-room for I, 0I4,000. Not a few of the Council's buildings, moreover, are in the central districts, the population of which either remains stationary or is declining-i.e., is migrating to the outer districts. Hence the houses which the Council have built in the central area contribute nothing to the solving of the housing problem, but only accentuate it by adding to the congestion. Here the question of overcrowding enters. The Royal Commission on London Traffic, in their report, made some observations which closely bear upon the Council's housing policy, and which, in a striking manner, show what a failure it has been. They pointed out that overcrowding and the average weekly rents of workmen's dwellings in the Metropolitan area were greatest in the central area, and tended to diminish towards the circumference, and that the price of land in the central districts made it impossible to rehouse the working classes there at rents which they could 
afford to pay without a heavy loss to those who undertake the rehousing. Then followed an illustration of the loss incurred by rehousing the working classes in the central portions of London as furnished by some recent experiences of the London County Council :

'In connexion with certain street improvements, especially the formation of the new street from Holborn to the Strand, the Council was required, under the authorizing Act, to build workmen's dwellings in place of those that were demolished. For this purpose they bought the Bourne Estate, close to the site of the improvement. The cost price was $£ 201,107$, being the commercial value. They were obliged to write this sum down to $£ 44,000$, its value earmarked for artisans' housing, and to debit the balance to the cost of street improvements. This was necessary in order to admit of charging rents within the means of the families to be provided for. Even after this writing down, they have had to charge rents from $9 s .6 d$. to IIs. a week for a three-roomed tenement, in order to reimburse themselves for this artificially reduced outlay. The buildings erected will accommodate 2,640 persons, and there is, therefore, a loss of very nearly $£ 60$ per head of the persons rehoused, and the whole of this loss falls upon the taxes. About the same time the London County Council purchased some land at Tooting, which is accessible by electric tramway, as well as by railway, in order to build workmen's dwellings. They acquired it at a price which required no writing down, and are now letting three-roomed cottages at Tooting at rents of 
from $7 s$. to $7 s .6 d$. per week. The Tooting scheme is self-supporting. The following figures will show how it is that the one scheme entails a very heavy loss, and the other entails no loss at all :

On the Bourne estate, actual cost of land for

a three-roomed tenement

Cost of building, etc. ..

Total
$€ \quad$ s. $\quad d$.

$\begin{array}{lll}454 & 4 & 0\end{array}$

$\begin{array}{lll}307 & 8 & 6\end{array}$

$\begin{array}{lll}76 \mathrm{I} & \mathrm{I} 2 & 6\end{array}$

On the Tooting estate, actual cost of land for

$\begin{array}{llllll}\text { a three-roomed cottage .. } & \ldots & \ldots & 28 & \text { I } 5 & 0\end{array}$

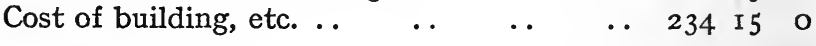

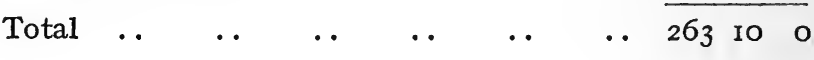

'The lesson to be learned from the two cases just cited', the Commissioners continue, 'is confirmed by every housing scheme, without exception, that the London County Council have undertaken: wherever they have had to provide workmen's dwellings in the central districts, there has been a heavy loss. In effect, the rents are largely paid out of the taxes. In the few cases where they have provided workmen's dwellings outside, the schemes have been self-supporting as far as houses have been built. A table appended to the report shows that, in the central districts, London taxpayers have sustained a loss of $£ 4 \mathrm{I} 2,683$ in rehousing 7,586 persons on $18 \cdot 55$ acres.'

But if the Council's housing schemes in the central districts were, at the time of the report, serious failures, events have subsequently shown that several of their 
suburban housing schemes are in like case. A writer in Municipal Notes ${ }^{1}$ points out that even the suburban housing scheme, and those at Tottenham and Norbury, are anything but successful. At Tottenham many houses will not let. The rents are too high for the overcrowded poor. There the Council have an estate which cost $£ 9 I, I 6 I$; on five acres of it were built I4I cottages at a cost of $£ 50,000$, the intention being to spend some two millions sterling in laying out the estate. The taxes, as usual, bear the burden (the cost is nearly equivalent to a rate of a penny in the pound on London) of what is a complete failure to make profitable a venture which there is no reason (except municipal methods) should not be a good one. One estate chosen for these cottages adjoins a cemetery, and railway stations are remote. At Tooting the rooms are too small, and not suitable for workmen. At Norbury little has been done so far as building is concerned. Certainly, the Norbury and Tottenham schemes are not for London workmen.

In view of what has been said of the London County Council's financial methods, it is not surprising that last year's accounts as published (to March 3I, I906) should be made to 'show' a profit. No one can take seriously the following figures contained in the report of the Housing of the Working Classes Committee of the Council $^{2}$ :

'The net result of the year's working', says the report, 'is a surplus of $£ 2,66 \mathrm{I}$ on all dwellings in occu-

1 November, 1905.

2 The Times, August 15, 1906. 
pation, to which must be added the sum of $£ 685$ in respect of interest on cash balances, making a total surplus of $£ 3,346$. The total financial results on all dwellings and estates owned by the Council from the opening of the first block in April, I894, up to March, I906, shows that a sum of $£ 56,882$ has been temporarily defrayed out of taxes, of which $f_{I} 7,798$ has already been repaid out of revenue from the dwellings, leaving a net contribution of $£ 39,084$ up to March last. Of this amount, the sum of $£ 30,823$ represents the sinking-fund charges and interest in respect of estates which have been acquired and are in course of development. Against the net amount contributed from the taxes, the following provisions have been made entirely out of revenues from the dwellings and estates: (I) $£ 29,295$ standing to the credit of the repairs and renewals fund after paying for all repairs and renewals required up to date, and (2) $£ 78,5$ II representing the amount set aside for sinking fund or repayment of capital with interest to date. This makes a total in hand of $£_{107}, 806$, and deducting from this the net contributions from taxes, $£ 39,084$, there is a balance in hand of $£ 67,722 . '$

As a diplomatic misrepresentation of the actual position of the Council's housing undertaking, this report is hard to beat. To pull it to shreds and tatters would be easy; but I shall spare myself the task by quoting what one distinguished advocate of municipalization (Mr Geroge Bernard Shaw) has to say about the method by which the Council is able to make an absolutely unproductive undertaking appear reproductive. Mr Shaw 
goes so far as to admit (and as a supporter of Municipal Trading of the advanced school, he is going very far indeed in doing so) that ' a municipality has to throw economics to the winds by buying land at its real market value, and charging it to its housing schemes at its value for working-class dwellings (a pure figment), the taxpayer making up the difference between this and the real market value. Having performed this conjuring trick, the municipality generally proceeds to pass a resolution that the dwellings shall be let at rents sufficient to prevent any loss coming upon the taxpayers, without mentioning that they have already borne a loss which does not appear in the housing accounts. Even then, the effect of the resolution, when it is strictly carried out, is to put the rents too high for the sake of enabling the borough treasurer to make a delusive demonstration that the dwellings are paying their way commercially. ' No more enlightening exposure of the figures in the report just quoted could be made than this. Indeed, one is rather startled to read the plain unvarnished truth written by an able spokesman for the municipalities, who, he would have us believe, can do no wrong. But his admissions do not stop short at an acknowledgment of deceptive accounting in municipal housing. 'Its opponents', he says, 'can always easily demonstrate that, in city centres at least, the schemes are commercially hopeless, and that, though the rents are too high for the tenants, they are yet so low relatively to the real site value that the tenants are virtually receiv-

1 The Common-Sense of Municipal Trading, chapter viii. 
ing a grant in aid of their wages at the expense of their fellow-citizens.' Here I find an unexpected endorsement of a view I have frequently expressed. Later on he runs foul of municipal block dwellings both from a utilitarian and an artistic aspect. What can be said of the following passage, save that, coming from a work entitled The Common-Sense of Municipal Trading, it is a direct impeachment of the 'common-sense' claimed for the policy, in that it points to the short life of municipal dwellings, with a consequent waste of money in building them on their present lines if social progress, as he prophesies, is likely to demand their demolition : 'These places seem at first so enormously superior to the filthy rookeries they replace that their revolting ugliness, their asphalted yards with the sunlight shut out by giant cliffs of brick and mortar, their flights upon flights of stony steps between the streets and the unfortunate women and children on the upper floors, their quaint plan of relieving a crowd on the floor by stacking the people on shelves, are overlooked for the moment, but long before they become uninhabitable from decay they will become as repugnant as the warrens they have supplanted. In short, the municipalities of the future will be almost as active in knocking our towns down as building them up.' They will, in other words, be consumed by a desire to eradicate these monuments of their early follies. Perhaps by that time they will also be brought to acknowledge their error in usurping a work in the carrying out of which voluntary enterprise has conclusively showed itself to be the superior. In fact, 
this doughty champion of the municipalities by implication admits that private enterprise is the proper agency for supplying houses, when he says ${ }^{1}$ that the municipality cannot compete with it; that private enterprise can supply everybody in a constituency, whilst a municipality in housing is restricted by law to insanitary areas and to workmen's dwellings; that a private builder can proceed much more cheaply than a municipality can; that a municipality is compelled to take the refuse of a trade, and to carry it on in the most expensive manner - that, in short, comparison between private and municipal housing is conclusively against municipal housing.

In several provincial cities where the local authority (not content to clear insanitary areas, and, that done, to lease the site to private persons at a good groundrent) build municipal houses thereon, no endeavour is made to 'show' that the undertaking has a 'balance in hand.' In Manchester, we are told ${ }^{2}$, the municipality has not attempted to carry out its rehousing schemes on a commercial basis at all, but has decided to treat them as part of a great work of 'sanitary amelioration', part of the cost of which should be met out of the local taxes. Here is a criticism of how they are carrying out the 'great work' by a member of the Manchester Municipal Council ${ }^{3}$ :

' One class of tenants has been scattered from the

1 The Common-Sense of Municipal Trading, chapter viii.

2 Municipal Year-Book, 1906, p. 494.

3 Mr T. R. Marr, Manchester Courier, January 16, I906. 
old slums, and another class has been catered for in the new tenements erected. Thus the 3 s. a week man has not found a new 3 s. a week house awaiting him when driven out of his condemned home. Houses have been put up at a rental that private enterprise would supply, and does supply, in sufficient number. Consequently, the Council not only fails in its first duty to the class which needs attention, but it creates a new evil by coming into competition with the builder and the landlord. A conspicuous example of this was found when a warren was destroyed where the rooms had been let at half a crown a week, and the tenants were told they could take themselves to certain municipal dwellings at a weekly rental of 5 s. $6 \mathrm{~d}$.- -now inhabited chiefly by municipal tramway employés.' As is the case in London, which I will presently show, the authorities drive out people from their slums without providing other accommodation within their means. The dishoused people only seek other slums. It is difficult to see how the pursuit of such a policy can promote sanitary. amelioration.

In Glasgow, the municipality acquired possession under statutory power of slum areas extending over 88 acres, occupied by a population of $5 \mathrm{I}, 000$ persons, the cost of the scheduled properties being about $£ 2,000,000$. A substantial portion of the land was disposed of to builders on chief rent or feu duty to a capital value of about $£ 300,000$. The remainder of the land was left on the hands of the municipality until I888, when they resolved to carry out a building scheme 
on their own account. They proceeded to put up a considerable number of shops and dwelling-houses, seven large lodging-houses, a laundry, and a family home the total value of the property thus erected by them being about $£ \mathrm{r}, 000,000$. To meet the cost of carrying out their improvement scheme the municipality had levied on the rental value of the city a rate which was fixed at sixpence in the $€$ for the first year, fourpence in the $£$ for the next four years, with subsequent reductions until one penny in the $€$ was reached, at which figure it stood until it was finally abandoned in I888. The charge on the taxes thus extended over a period of more than twenty years, and the total amount actually contributed by the taxpayers has been put at $£ 600,000^{1}$.

Birmingham, at first, having cleared its insanitary areas, was wiser. The municipality leased the greater portion of the land to private builders, and obtained annually therefrom in ground-rents the substantial sum of $£ 45,902$. This is a simple way of carrying out a housing scheme on a commercial basis, and also as a great work of sanitary amelioration, for private enterprise, subject to the sanitary laws, and also possessed of a civic conscience, can be depended upon to keep its properties in a fit condition-even without control. Birmingham, however, has been unable to withstand the temptation to build houses on its own account on other portions of land acquired, with the result that one scheme has involved a loss of $3 s$. per house per week, or $£ 7 \mathrm{r} 6 s$. annually per house, and another a loss

1 Municipal Socialism, reprinted from the Times. 
of Is. $3 d$. per house per week, or $£ 35$. annually per house. On an estate of Ioo houses, the loss stands out as a needless debit item against the large sum the municipalities receive from the lessees of their land. Of late, it is instructive to learn, the Housing Committee of the Birmingham Council have been seeking guidance from Germany, which country they visited. In their report, as published ${ }^{1}$, they expressed the opinion that a municipality cannot own too much land, provided that it is judiciously purchased. The municipality could then assist private individuals and public building societies, with whose bona fides they were satisfied, to erect at the lowest possible rate cheerful houses for people with small incomes. The policy of buying land and encouraging other people to build the houses, they declared, would enable the municipality to give a great stimulus to the supply of good and cheap houses on the outskirts of the city, and would thereby benefit a very large number of people. On such a pronouncement, there is apparently hope that Birmingham will return to its early policy, after clearing insanitary areas, of leasing the land to private enterprise.

Liverpool has experimented in housing schemes to a greater extent, perhaps, than any other city. The municipal Council's tenements now number 1,567 , including those now in course of construction as planned. The cost up to the middle of I905, together with the "valuation of sites for housing purposes,' has been published at $£ 332,000$ (the actual cost is not shown), and the charge

1 Birmingham Daily Post, June 2, 1906. 
on the taxes is $£ 3,600$ a year. Only lately attempts were made to force the Housing Committee of the Liverpool City Council to prepare a scheme for the erection of houses in the outlying districts of the city on land at present in the possession of the Estate Committee, or on other suitable sites. But the committee reported that during the last five years about 2,000 houses at rentals ranging from $£ I 2$ to $£ I 8$ per annum, and 4,500 houses at rentals ranging from $£$ I8 to $£^{25}$ per annum, had been erected by private enterprise in the outlying districts. This vividly impressed the committee with the fact that the city could not compete with private enterprise, and they seriously doubted whether the city could offer inducements in respect of rental if the undertaking proposed is to be conducted on a commercial basis. As, therefore, there was no lack of accommodation, sufficient houses being provided by private enterprise, the committee did not recommend the city to enter into competition with private enterprise in the outlying districts, and the Council, with tardy wisdom agreed not to do so.

This city's experience was brought before the Leeds County Council, when a proposal to erect workmen's dwellings in thit city was submitted, which drove the chairman of the Unhealthy Areas Committee (Alderman Lupton) to resign because of his disapproval of municipal houses. As reported in the Yorkshire Post of May 3, I906, he said, speaking of Liverpool, that 'two blocks of tenements, costing $£ 84,000$, produced net receipts for I903 of $£ 2,920$, which was about $2 \frac{1}{2}$ per cent., 
and showed a considerable loss when interest and sinking-fund charges were included. Another scheme costing $£ 65,277$ showed net receipts for I903 of $£$ I,I37, and that was all there was to meet interest and sinking-fund charges. Four years ago Liverpool had completed or had in course of erection 797 houses. The loss per annum on these was calculated at $£ 4,300$. They were then proposing to build 4,800 houses, and expected the loss on them to be $f_{\mathrm{I} 2,400}$ per annum. He advised the Leeds Council that they ought not without urgent necessity to build at a loss. He said tenement houses were in themselves an evil. Municipal building was not only costly in itself, but tended to discourage other building, and to restrict rather than to increase the supply of houses.'

This is really what is now happening, especially in London, where, since the County Council and the borough authorities went into the housing business, the great companies, which had housed thousands of the working classes, have been seriously handicapped in erecting further dwellings. But for municipal interference, these further undertakings would duly come into existence in relief of a pressing problem. It would seem at first sight that the relief which private enterprise has been prevented from effecting has been afforded by the municipalities, so that the same end is arrived at by a different agency. But the London municipalities are not solving the housing problem; they are only accentuating its complexity by their methods. As in Manchester, they clear away slum property, by which 
a large number of the extreme poor are dishoused, and on the vacant land they build tenements which are let at rents entirely beyond the means of the dishoused people. The rooms become occupied by an entirely different class of the population, who can afford to pay the higher rents charged, whilst the slum poor dishoused seek other slums, or, if they can, obtain accommodation in a private model dwelling, the rents of which come within their narrow means. But as the development of cheap private dwellings has been crippled by the municipal policy, the dishoused poor have less and less chance of finding a harbour open to them in that direction. From slums they go and to slums they return.

The London County Council and the local authorities have merely tinkered with a vast problem. The more poor which are dishoused, the more are made homeless. This is a phase of the question which affects the social well-being of the poorest section of the community, of which municipalities are supposed to be very regardful, with the help of the public coffers ; but the outcome of their exploits in this direction knocks the bottom out of the principle of benevolent service to the poor they claim to give, because the poor are left to shift for themselves, and the class above them become the municipal tenants.

The other class which suffer are the private houseowners and builders and contractors. Municipalities build huge tenements on a luxurious scale, which tempt all manner of tenants from the houses they were previously content to occupy, with the result that there is a 
marked depreciation in house property; while private builders, not having public money as their capital, are unable to run to the same extravagance in erecting dwellings in competition with the local authorities, and are discouraged in their operations.

The simple truth is that a municipal model dwelling, whether it pays or does not (and it mostly does not), is tangible evidence of the 'benevolence' of the city fathers toward the working-class voter. It impresses him even greater than the municipal street railway does, because he lives in it. The building is ' his', he is told, and it is his bounden duty to live on his own property. As an electioneering device, therefore, there is much to be said for municipal housing from the point of view of the dominant party in a local council whose policy it is.

Another object of building municipal houses is the onus forced on the municipalities of justifying the creation of the huge municipal 'works departments', equipped with enormous plant, and employing thousands of workmen. The existence of such establishments means finding employment for the men: something must be done; the works must be kept alive. A certain amount of municipal building is therefore carried on year by year, and the promotion of the municipal housing policy provided a convenient way of utilizing the works. In the domain of private enterprise, business activity will necessitate the promotion of new undertakings. The establishment of contractors' works, from which issue the necessary material, and 
where the equipment is prepared, follows as a matter of course; but such works are subsidiary to the particular undertaking in hand, from which they originate, and but for which they would not exist. The rule of contrary, as shown, governs the creation of municipal ' works departments.' They are built with the ostensible object of drawing workmen to them. As municipal employés, the men perform their part in building municipal houses, which they duly occupy, and become voters, ardently supporting a policy that insures them permanent employment at standard wages (the London County Council being at the bidding of the unions)-i.e., wages paid without reference to the individual capacity of the workman-whether good, bad, or indifferent, he is paid at the same rate. Here we come into touch with the problem of the unemployed. It is a fact that in times of distress, certain municipal bodies, bound as they are to Trade Union despotism, have been obliged to offer Trade Union wages even for such relief work as road-mending, and that men have left their steady work in neighbouring factories to join the road gang for the higher pay, only to find themselves within a few weeks enlisted in the ranks of the unemployed.

Three strong and insuperable objections to the whole principle of municipal house-building have been raised by Miss Octavia Hill, than whom no one is better qualified to speak of the question as it relates to London. Added force is lent to these objections in that they cannot be controverted. They are :

(I) The work will be done expensively : no body like 
the London County Council can be an economical one. The cost must be met in one form or another. Why should we prefer to pay in taxes rather than in rent? The mode of payment by taxes will press heavily, being inexorable, and not elastic.

(2) The London County Council, which ought to be the supervising authority, will itself be pecuniarily interested in the houses to be supervised.

(3) The electorate will be in a large measure composed of the tenants of the body to be elected.

The second point means that whilst the Council, as a statutory authority, supervises other slums, and enforces the provisions of the various building and sanitary Acts upon their proprietors, as a slum landlord it is free from supervision, unless it attempts to supervise itself. Municipalities have tried many things and failed, and that would be the greatest failure of all. On the third point, it may be commented that if the houses are let at commercial rents, at once a privileged class of tenants is created, as even Mr Bernard Shaw admits. In a previous chapter consideration has been given to the danger to which this may lead.

The first point, relating to the greater cost of municipal house-building as carried on in Great Britain, admits of more detailed illustration than has already been given to it. Here are some causes for the greater cost-some, it is true, inherent, but most of them arise from the volition of the municipalities ${ }^{1}$ :

(I) Under the slow procedure enjoined by the Artisans'

1 Summarized from 'Municipal Socialism' (The Times). 
Dwellings Acts of 1875 and 1879 , opportunity is afforded unscrupulous private persons to buy up insanitary areas condemned to demolition by a municipality, whereupon they raise the rents, and the houses are bought subsequently by the local authority on the basis of the enhanced income.

(2) Various costly administrative expenses are incurred before a brick is removed. So heavy, indeed, may the expenses be that in the carrying out of a municipal housing scheme under Part I. of the Act, the London County Council has before now been put to a cost of fIoo per head for every man, woman, and child who would inhabit the dwellings before even a single brick has been laid.

(3) The subterfuge of writing down the value of sites secured for housing purposes (of which some examples have been cited) in order that, on the rents charged, the undertaking may be made to appear to 'pay.' Witness the report of the London Council's Housing Committee which has been quoted. Another instance of the method is a site at Clerkenwell, bought by the Council for $£ 200,000$, the value of which, for 'housing purposes', was written down to $£ 45$, 000. The difference between these figures ( $£$ I55,000) represents the cost, in the case of this particular site, which has to be borne by the taxpayers. That the Council has to buy land at its commercial value is the penalty it pays for interfering with the housing company. Before they came on the scene in I899, private enterprise was doing the same work under advantages which sellers of land 


\section{THE DANGERS OF MUNICIPAL TRADING}

now deny them, and also deny the Council. The housing companies found that the poor man in London could not be decently housed at a rent he could afford to pay if, at the start, the land were bought at its market value, for in that case the ground-rent per room per week worked out at a prohibitive total rental. They therefore besought the generosity of the groundlandlords of London to let them have land at a price which would enable them to charge their poor tenants a land rent of no more than $3 d$. per room per week. The ground-landlords responded, and sold them a great deal of land on terms six and twelve times below its market value, one of them (the late Duke of Westminster) sacrificing several thousands of pounds sterling a year through making such generous concessions to the companies in order that their rentals could come within a poor man's means. But when the companies wanted to buy suitable sites from the County Council, no such consideration was shown them; the Council demanded the full market value of their land, and also imposed their various restrictions. At the Council's price, the land rent of one site per room per week, including taxes, worked out at as much as Is. $6 d$., whilst by imposing that the number of stories should be four instead of six, as the Council did, the company would be obliged to reduce the number of rooms, thus increasing the proportion of land rent each tenant would have to pay. The result has been, as far as the companies are concerned, that not a single site has been bought by them from the Council; they preferred, instead, to purchase 
their land from private owners. As for the latter, the municipal policy has reacted substantially in their favour, for when they found that the Council sought to sell their land for housing purposes at the full market value, they regarded themselves as released from the obligation to sell on the cheaper basis ; but the companies chose to buy land from them on the higher terms rather than buy from the Council. The consequence was that the Council had a great deal of land on its hands, that no one would buy on the prohibitive terms demanded. They built on it themselves on the pretext that private enterprise was a failure, because no purchaser would come forward, and in doing so they promptly hit upon the expedient of writing down the value, in order to give the housing undertaking the semblance of a payable proposition, thus according to themselves all the concessions which they denied to the private companies, and which the latter were able to obtain from the ground landlords before the Council interfered with the housing industry.

(4) A municipality being thus obliged to build, there arises an anxiety on the part of municipal officials, for their credit's sake, to make a 'good job' of the houses, which tempts them to add various ' extras', ornamental or otherwise, that a company working on commercial lines, and regarding every penny spent on the cost of production to be made up ont of the rents, would be disposed to do without.

(5) The lower speed at which municipal workmen perform their labour, combined with the overloaded 
officialism which marks municipal works departments, and consequently means higher cost of administration.

(6) The probability that even if the building were given to a contractor, he would charge more to a municipality than to a private person, because his men, knowing the work to be municipal, would be just as leisurely as municipal employés, and he would be subject to many restrictions and interferences, from all of which he would be exempt were the undertaking a private one.

(7) The statutory obligation of a municipality t , pay off its loans within a limited period, which involves a much heavier annual contribution to the sinking-fund paid out of receipts than private companies find necessary.

In view of all these disabilities, it is surprising that any sanely managed municipality should be desirous of embarking on such a hazardous undertaking; but the bottomless resources of the taxes enable them to slide smoothly over all these obstacles. The increased local taxation which follows the pursuit of municipal housing so circumscribed is felt as much by the housing companies as by anyone else, and joined to other hindrances to their development makes cheap housing accommodation more and more of an impossibility as time goes on. Indeed, 'such is the position in regard to the cost of building artisans' dwellings at the present time that, although housing companies and trusts managed on business lines secure profits ranging from $2 \frac{1}{2}$ to 4 or 5 per cent. (as compared with the losses too often sustained on municipal dwellings), it is morally certain 
that if any new company were to start operations within a reasonable distance of the city of London, it would not be able to earn more than about $2 \frac{1}{2}$ per cent. It is doubtful, moreover, if any such new company would now be started at all in London, for existing companies find that, owing to the policy adopted in regard to municipal dwellings, there is a growing reluctance on the part of the public to invest in private housing companies. The check given to trusts and companies has naturally been even keener in the case of individual builders with smaller resources to fall back on; but when one bears in mind what enormous collections of small house property have sprung into existence of late years in the neighbourhood of Edmonton, Walthamstow, and other districts, converting hamlets into populous towns, there is still further reason for suggesting that private enterprise has done much more than the advocates of municipal house-building are willing to give it credit for ${ }^{1}$ ' In fact, notwithstanding the unfavourable conditions created by the municipalities, between I883 and up to March, I905, private builders in London succeeded in providing, exclusive of small houses, working-class dwellings with an aggregate number of II3,I47 rooms, at an average weekly rental of $2 s$. $4 d$. per room. On the other hand, the whole of the London municipalities have only provided housing in the same period to the number of 21,065 rooms; whilst the average weekly rent per room charged by the London County Council is 2s. IId.

1 From 'Municipal Socialism' (The Times). 


\section{THE DANGERS OF MUNICIPAL TRADING}

In conclusion, the social and economic conditions which do not favour the intrusion of the State or municipality into the industrial field are particularly manifest in the case of housing. The more houses a State builds, the more houses will other people be prevented from building. That means stagnation of voluntary enterprise, which can be beneficial to no nation. Then the influences behind State action differ widely from those which move private persons (namely, monetary profit and personal well-being) to initiate and develop housing undertakings. Competition keeps the latter up to the mark; but the vigour of State enterprise wholly depends upon the pressure with which the general public and the taxpayer actuate the government machinery. Such pressure is strong only intermittently. Usually impulsive, it is merely expressive of a temporary frame of mind, and is generally followed by long periods of apathy, which encourages State and municipal officials to a lax and sluggish performance of their duties. Not having the same spur to action which urges voluntary enterprise to do its best, an increase of knowledge and of skill on the part of governmental officials is not to be expected. With the best will in the world, any zeal which they may accidentally show is likely to be choked by the usual rigid system of red tape, regulations, and precedents. Incentives to enterprise in government departments, therefore, do not exist, and it is idle to argue that efficiency of management is possible under such conditions. 


\section{CHAPTER XVI}

NATIONALIZATION OF RAILWAYS

$\mathrm{T}$ the United Kingdom the sentiment in favour of 1 Government working of railways does not appear to be very strong It has certainly not assumed the importance it has in the United States, where the question is being discussed and the policy advocated by $\mathrm{Mr}$ Bryan, a prominent candidate for the Presidency. I have added this chapter to the English edition of the work because I believe it is a phase of the public ownership danger which cannot well be ignored. $\mathrm{Mr}$ Dixon H. Davies generously gave me permission to use, with slight alterations, a paper he read on January I6, I907, at Nottingham. In this paper the question is so clearly and concisely brought before the reader that it has seemed to me it deserved a more permanent form of publication than that of the Great Central Railway Journal in which it made its appearance.

There is not, according to $\mathrm{Mr}$ Davies, ${ }^{1}$ in the principles

1 Mr Dixon Davies desires to express his acknowledgments in the preparation of this paper to the invaluable works of Professor Meyer, of Chicago ; and to his friend and pupil Mr Alfred Hacking, who, with much industry 
of English institutions anything to account for the fact that in this country, in contradistinction to the rest of Europe, the whole of the railways are in private ownership. On the contrary, the customs of the AngloSaxons, those stern restricters of the functions of government, contain the most definite sanction for making the provision of communications a public charge. The maintenance of the highways was ranked with the repulsion of invasion, and the ransoming of the Sovereign as the trinoda necessitas of public burden. It is true that at a very early date that saving vice of AngloSaxon collectivism-inefficiency-supervened, and the excellent network of military roads traced by the Romans became so overgrown and founderous that it was hardly possible to discover the track even of the trunk lines, and in the early Plantagenet days posts were ordered to be set up at convenient intervals along the main roads, to each of which a horse was tethered, so that the King's messengers might ride from post to post, changing horses as they proceeded. Thus was established the system of Governmental communications which all other nations not only copied, but by their adoption of its English name paid unconscious homage to the British as the pioneers of the transport industry. ${ }^{1}$

and resource, has compiled the statistics; also to his friend $\mathrm{Mr}$ W. H. Edge, whose able and informing paper on this subject appeared in the Great Central Railway Journal of May, 1906.

1 It is, perhaps, needless to remark that there are foreign authorities who do not accept this derivation. 
But beyond establishing a few horse-posts, Government did little or nothing for the communications of the country, and by the time wheeled traffic came into general vogue, the roads had sunk to mere bridle-paths, and protests rose loud and frequent from all parts of the kingdom; amongst these was a petition to Parliament from Nottinghamshire that one of the main roads was so narrow in places that two pack-horses could not pass each other. Pack-horses continued to be the principal mode of transport down, at all events, to the middle of the eighteenth century, their convenience being that where the road was founderous they could take advantage of the common-law right, and deviate from the highway on to the adjoining lands. In Smollett's novel of Roderick Random his hero leaves Glasgow for London in 1739 between the panniers of a pack-horse, there being no other regular means of communication between Scotland and England at that time.

The cost of transport was naturally prohibitive. What was called a fast van from Manchester to London charged $£ 20$ a ton. The incredible condition of poverty and backwardness of the interior of the country which prevailed at this time demonstrates the degree to which civilization is dependent on transport. In Southey's Doctor it is stated that in hundreds of English villages at the end of the eighteenth century cotton and sugar were unknown commodities, and even the potato had not yet penetrated. In I790 Robert Owen pulled half a sovereign from his purse to pay a toll on the main road 
between Glasgow and Lanarkshire. The pikeman refused to take it, having never seen gold money before!

The scandal of this state of things was pressed upon Parliament, but when they proposed to lay out public money on the roads they were met with strong opposition by those who profited by the absence of competition that resulted. There is, for instance, on the rolls of Parliament a petition by the market-gardeners of Hammersmith, protesting that the proposed improvement of the western road would deprive them of their natural advantage in the London market, which they claimed to enjoy as a right-a petition which, to those accustomed to the arguments railway-men have to face nowadays, has a ring of familiarity.

Thus early did the difficulty of adjusting public enterprise with the conflicting interests of different localities make itself felt, and thus early was the solution of the difficulty found by a resort to private initiative. The highways were handed over to the private control of the turnpike trusts, who quickly reduced the chaos to something like order. It was not perfect, but, compared with the state of things which preceded it, the improvement seemed a marvellous revolution. State ownership, represented by the Post Office, was immediately left hopelessly behind, and the post was reputed the slowest as well as the most precarious means of communication. It was little used. In I740 there were only three posts a week between London and Edinburgh, and on one occasion it is recorded that the post carried only one letter. It was not till I734 
that the Post Office could be persuaded to send the mails by coach.

As the Post Office is frequently referred to as a model of what State enterprise can do, it may be pointed out what a fortunate thing it is that national communications have not been trusted entirely to that department; for, notwithstanding the admirable opportunity which they had enjoyed for centuries as monopolists of through communication, they have not been the initiators of any striking improvement, but have only adopted the inventions of private people with the utmost reluctance. Their opposition to telephones and boy messengers in these days is all of a piece with their neglect of carriage roads and of mail coaches in earlier times.

This attitude of State resistance to improvement should not surprise us. It is only what is to be expected of Governmental institutions-at all events, in a democratic country, for all the Government of a democracy can do, at its best, is to reflect the views of the majority. Industrial advance has never proceeded from the majority; its source is always the brain of one man or a few men, who manage to persuade one or two others to believe in their invention, which they proceed to carry out amidst the scorn of the rest of the world. This was the history of the introduction of railways. Pease and Stephenson were almost alone until they demonstrated the practical success of railways, made money for themselves and afterwards for their friends, who had thought they were mad, but were glad enough to come in and share when they saw prosperity. Parlia- 
ment abused and oppressed the railways, exposed them to the pillage of greedy landowners, and subjected them to the necessity of bridging so as to maintain the existing imperfect public and farm roads without interruption, thus forcing them to an artificial level above or below the surface. This obligation, by the way, more than anything else, accounts for the huge capital expenditure on British railways-some three times the average cost abroad. But notwithstanding unfair exactions, and not a little ill-natured opposition, the railwaymakers grew and prospered. Not content with providing lines at home, their equipment and resources became so developed that, as the demand arose in other countries for the new system, they were the people who got the business to make them, and so they built up, as contractors, as engineers, as locomotive and carriage builders, or manufacturers of plant of all kinds, as financiers, or as mere investors, that vast aggregate of small fortunes from which have mainly been drawn the unfailing supplies of wealth for the prodigious and apparently insatiable requirements of the railway system.

Let us turn for a moment to the history of foreign road-making. In this respect there can be no question that countries on the Continent were greatly in advance of Great Britain. Numerous causes, partly dynastic, partly religious, partly territorial-perhaps more than anything else racial-had moulded the social institutions of the Continent upon a system of centralizationa system which, taking no account of local objections, 
and having for its ideal national completeness, certainly had the advantage of furnishing the country with a network of splendid roads. The system was no more capable of invention than was democracy, but it had the further disadvantage that it did not give the same opportunity of progress to its citizens. The whole of the national life was restricted in its development by a rigid system of regimentation, which spread the net of bureaucratic routine over the social life, and restrained the energies of the people in the arena of industry as effectively as the movements of their feudal ancestors were hampered by their plate armour on the field of battle. To the powers that were, in such a state of society, the railway, levelling in its democratic advance strongholds of privilege and prejudice, was not altogether a welcome change; but economic reforms cannot long be resisted-railways had to come. The question was, Where was the money for such industrial improvements to be found? Napoleon had inquired of financiers, who had humbly told him that he could not manipulate millions with the ease with which he was accustomed to manœuvre battalions. Abroad there were no small fortunes in the hands of a large commercial class ; the people had not had the opportunity of developing industrial enterprise that the British had. While the French were engaged in cutting off the head of their despot, the English, having achieved that curative operation some century and a half earlier, were beginning the Great Central Railway. Perhaps it is not generally known that the earliest part of the company's system- 
viz., the Peak Forest Railway-was commenced in the year I789, the year in which the Bastille fell. By this and similar enterprises the people had long been trained to take their courage in their hands, and face large commercial adventures by voluntary co-operation, and without dreaming of State assistance; and at the dawn of the railway there was already in Great Britain an army of small capitalists from whom the railway-makers could recruit their pioneer ranks. But the small capitalist did not exist to anything like the same extent in foreign countries at the time when railways began, and his absence is the real reason why so many of the Continental railways started under national auspices. The State had to make them, because there was no one else who could, or who would find the means.

It should be borne in mind with pride that England is the only country in the world that has not in one form or another given State aid to railways. It would be a mistake to suppose that relief from public indebtedness is the only benefit that has resulted from this unique circumstance. Perhaps a greater advantage is the automatic proportioning of effort to demand which results naturally from commercial control. If there is the public purse to draw upon, how are the projectors to fix the limit? They may either overdo the provision, as was certainly the case in the United States, where, in order to earn the public grants of land or money, the railways were pushed out in advance of the population, and led to widespread overtrading and ruin; or they may lag behind the demand which would appeal 
to commercial people, with a result such as is seen in Australia, where the great agricultural territories remain uncatered for, and the population is unnaturally and mischievously concentred in the three or four great towns.

Commercial control, on the other hand, operates like the governor of an engine. If it has developed a pace beyond the necessities of the load, the steam - that is to say, the capital resource-is cut off by the resulting discontent of the shareholders; if it falls short of the occasion, the unserved demand offers attractions which quickly draw capital and proportionately induce expansion. Thus the machine neither races nor lags. Overtrading is checked, insensibly and naturally, and undertrading is overtaken.

There are, however, certain advantages which are commonly claimed for State railways. It is said they serve military purposes better, but whether they do so or not must depend upon whether the State is capable of providing a system sufficiently well spread and well equipped. In Great Britain, for instance, it is difficult to conceive how, on the top of other demands for public expenditure, it would have been possible for the Government to have furnished the sum of thirteen hundred millions which commercial people have laid out upon our railways. This vast sum, as above explained, is itself the creation of free industry, and to a very large extent the creation of the railways which have thus themselves provided for their own growth and subsistence. As to the management of the railways for military purposes, 
those who studied the history of the South African campaign formed the opinion that the transport operation achieved by the privately owned railways and privately owned ships was the most creditably performed part of the whole business.

Another advantage of national railways which is thought a great deal of in foreign countries, where it is the ambition of every citizen to become an official, is that the system lends itself to enormous bureaucratic aggrandizement. This is a characteristic, however, on which English people are not disposed to place a very high valuation.

Still another merit claimed by some is that national railways contribute to the revenue of the State. It is exceedingly doubtful whether they could be made to do so in England, for the reason that the profit of a public undertaking, whether it be a State railway or a municipal gasworks, is not really a profit, but a tax. As it is a principle of both England and the United States that people should be equally taxed according to their means, it is not likely that the men of business, who furnish the principal traffic to the railways, would consent to have conveyance charges maintained against them for the sake of relieving the burden of the taxpayer at large. Again, revenue derived indirectly in this manner relieves the Government from the check of the purse-strings, which it is the function of the House of Commons to exert upon them. If our Ministers had, like those of Prussia, a source of revenue equivalent to half the national expenditure which did not require 
to be voted in Committee of Ways and Means, the power of the House of Commons would be a very different thing from what it is to-day.

Yet another claim is made for State railways-it is that they rest on a system of uniformity and simplicity of rates. It is true that this is the tendency and, in theory, at least, the primary basis on which State ownership proceeds. Herr von Miquel, the Minister of Finance, stated in the Prussian Diet of 1894 ' that it would prove impossible to retain the State ownership of the railways in Prussia unless it should be practicable to make rates in accordance with hard-and-fast rules, such as those based upon cost of service. It would be impossible', he said, 'to make rates for particular occasions to meet the needs of those occasions; for rates made in that manner were arbitrary, and exposed the Government to the suspicion and to the open charge of favouring one district or trade and handicapping another.' This talk of equable rates is mere fiction reserved for Minister's speeches. The practice of railway management is very different from the politicians' theories, as I shall shortly show.

The Railway Ministers of all countries-republican France, military Germany, autocratic Russia, democratic Switzerland, constitutional Italy, monarchic Austria-profess that if railways are to be national rates must be stereotyped, rigid, incapable of adjustment, and removed by their mathematical simplicity beyond the range of discussion. It is well to observe, however, that the theory of uniform rates was not the 
cause of State railways abroad, but the political result of nationalization.

The economic error which underlies such views is very clearly set forth in the following extracts from the Report of the Interstate Commerce Commission of the United States (vol. i., I888, p. 303) :

It was very early in the history of railroads perceived that if these agencies of commerce were to accomplish the greatest practicable good, the charges for the transportation of different articles of freight could not be apportioned among such articles by reference to the cost of transporting them severally ; for this, if the apportionment of cost were possible, would restrict within very narrow limits the commerce in articles whose bulk or weight was large as compared with their value.

On the system of apportioning the charges strictly to the cost, some kinds of commerce which have been very useful to the country, and have tended greatly to bring its different sections into more intimate business and social relations, could never have grown to any considerable magnitude, and in some cases could not have existed at all, for the simple reason that the value at the place of delivery would not be equal to the purchase price with the transportation added. The traffic would thus be precluded, because the charge for carriage would be greater than it could bear. On the other hand, the rates for the carriage of articles which within small bulk or weight concentrate great value would on that system be absurdly low-low when compared to the value of the articles, and perhaps not less so when the comparison was with the value of the services in transporting them.

It was, therefore, seen not to be unjust to apportion the whole cost of service among all the articles transported, upon a basis that should consider the relative value of the service more than the relative cost of carriage. Such method of apportionment would be best for the country, because it would enlarge commerce and extend communication; it would be best for the railroads, because it would 
build up a large business; and it would not be unjust to property owners, who would thus be made to pay in some proportion to benefit received. Such a system of ratemaking would in principle approximate taxation, the value of the article carried being the most important element in determining what shall be paid upon it. . . . Of the duties devolved upon the Commission by the Act to regulate commerce, none is more perplexing and difficult than that of passing judgment upon complaints made of rates as being unreasonable. The question of the reasonableness of rates involves so many considerations, and is affected by so many circumstances and conditions which may at first blush seem foreign, that it is quite impossible to deal with it on purely mathematical principles, or on any principles whatever, without a consciousness that no conclusion which may be reached can by demonstration be shown to be absolutely correct. Some of the difficulties in the way have been indicated in what has been said on classification; and it has been shown that to take each class of freight by itself and measure the reasonableness of charges by reference to the cost of transporting that particular class, though it might seem abstractly just, would neither be practicable for the carriers nor consistent with the public interest. The public interest is best served when the rates are so apportioned as to encourage the largest practicable exchange of products between different sections of our country and with foreign countries; and this can only be done by making value an important consideration, and by placing upon higher classes of freight some share of the burden that on a relatively equal apportionment, if service alone were considered, would fall upon those of less value. With this method of arranging tariffs little fault is found, and perhaps none at all by persons who consider the subject from the standpoint of public interest. Indeed, in the complaints thus far made to the Commission little fault has been found with the principles on which tariffs for the transportation of freights are professedly arranged, while applications of those principles in particular cases have been complained of frequently and very earnestly. 
In a recent speech by Mr Lloyd George, that Minister expressed surprise at the continual stream of complaint about railway rates which reached his department. That is hardly a fact to excite surprise. Delicate as is the operation of correctly adjusting a railway rate, it is one which its most practised professors would not claim to be a matter of exact science. The process is at best a compromise, in which the trader is always trying to cheapen the bargain he is making. Did anyone ever hear of a trader expressing satisfaction with the price he was paying for anything? Certainly not in the hearing of the other party to the bargain. "It is naught, it is naught, saith the buyer; when he goeth away he boasteth.'

It seems to be overlooked by public men when they make speeches sympathizing with these aggrieved traders that the class of complaint most frequently received by the Board of Trade is an appeal for particular rates to special traders and places, which, if granted-and that is why they are asked-would place the petitioning trader or locality at an unfair advantage with other persons and places with which competition under normal circumstances is not economically possible. It is for this reason that so few of these complaints ever see the light of day in the Railway Commissioners Court. They would not stand scrutiny for a moment. The last volume of the railway and canal cases, which covers three years, only contains eighteen cases. No doubt there were others which the reporters did not consider of sufficient importance to record, but having regard to 
the magnitude and ubiquity of the daily railway transactions, it may be doubted whether any branch of commerce has ever been conducted with so much ease and so little litigation.

The cry which reaches the politician is that the companies are using their power as monopolists to oppress the trader. This generally involves a double pretence. First, the party complaining is not the public, but an unsuccessful trader masquerading in the clothes of the public; secondly, what is complained of is not the action of the company as a monopolist, but the reversethat is to say, its competitive activity. Take the case of the complaint that the South-Western Company were carrying American meat from Southampton to London at lower rates than home-fed beef. When the case reached the Commissioners' Court, that tribunal found that the complainants, though nominally an association of traders, were, in fact, one of the London dock companies, who were suffering because the land carriage of the railway company was proving itself more efficient than the sea carriage up the Channel, and thus, by its competitive superiority, diverting the traffic from the longer sea route, to the disadvantage of no human being except the dock proprietors.

But Mr Lloyd George goes on to suggest, as do equally prominent politicians in America, that there is no similar complaining about the German railways. It would be interesting to know from what source the President of the Board of Trade has derived his information. It may be confidently asserted that he is under 
an entire misapprehension. The following instances show that there is a constant undercurrent of agitation amongst the traders and manufacturers in Germany, which now and then breaks out, in spite of the most stringent efforts of the autocratic administration to confine complaints within the official bureau.

A few years ago persistent requests were addressed to the Prussian Railway Department to lower the railway charges affecting the iron trade. It was pointed out that these were so high that the proportion of the costs of pig-iron production due to transport amounted to 25 per cent. of the total in Germany, as compared with ro per cent. in England. Notwithstanding these appeals, the charges in question were not lowered for sixteen years-namely, from I88I to I897. And they are still maintained at an excessive figure compared with the transport charges on English pig. For years the manufacturers of the Ruhr district asked for lower rates from the Alsatian iron-beds. They could not get them, for it was said ' the Government could not make reductions which would render it liable even to the suspicion of preferring one district.' In consequence, they are using Swedish and Spanish ores, and one of the finest iron-beds of the world remains comparatively undeveloped.

The agriculturalists of Eastern Prussia petitioned for a reduction of the rates on their grain to the Rhine district, which had remained the same for eleven years, and were so high as to be prohibitive, so that the corn had to be sent by water to the Baltic, whence it was transferred 
to ships that took it all round Denmark to Rotterdam, and thence up the Rhine. After at first refusing to depart from the uniform system of rates, extended crop failures induced the Government to yield a lower rate, so that the mining and factory population might get grain and flour. Thereupon the farmers and millers of Saxony and other parts protested, like the marketgardeners of Hammersmith above referred to, and they threatened that if they were not restored to their natural advantages their representatives would not support in the Reichstag the Government policy with regard to a treaty with Russia. Under this pressure the Government gave way, and in I894 restored again the prohibitive rates of 1877 against East Prussia.

The mills at Dresden draw their corn from Roumania, but though there is a direct railway, such are the rate obstacles that every ounce of that corn is sent round by the Danube, the Black Sea, the Mediterranean, the Bay of Biscay, the German Ocean, and up the Elbe, through Hamburg.

The story of the rates upon the nationalized railways of Germany is shortly this :

The Government started out in I87 I with the same excellent intentions that are evidently influencing the mind of our own President of the Board of Trade to-day. That is to say, to provide a remedy for commercial inequalities by establishing 'natural rates.' Every ton of goods, of whatever character, was to pay a rate made up of two parts : (I) A fixed charge for terminals, and (2) an equal charge per mile. The effect was disastrous. The cheaper commodities could not stand the rates. There was a universal outcry; so in 1877 , to save industrial disaster, as 
well as to pacify the public, the German Government threw over their 'natural rates', and adopted a 'reform tariff', being a retrogression to the system of classification with varying rates per mile. But still short-distance traffic was strangled, and the traders cried out. Then followed the cutting of a bit off the terminal, and the sticking of it on to the mileage charge. This injured those interested in the through traffic, and again there was a public agitation, whereupon the Government was driven into establishing an elaborate series of special export and other rates, called a 'preferential tariff.' Even this failed to satisfy the public, and various traders continued to clamour for consideration for their particular industry. Once again the Government were driven into originating special rates, much the same as the special rates of the English railways, and it appears from official records that to-day only 20 per cent. of the total traffic is handled on the 'reform tariff', 63 per cent. on the 'preferential tariff', and I 7 per cent. under the 'special rates.'

The German Government started with the intention of providing a simple and equable tariff. It has had to abandon that lofty aspiration, just as English railways are forced to depart from uniformity in conceding special rates, without which certain traffic could not be brought into existence, so that the German Government has, in fact, followed in the steps of British and American practice. The difference is that in Germany a concession cannot be secured except by the exertion of public agitation, and in some cases unpatriotic pressure, on the Ministry, whereas in England rates are arrived at by amicable negotiations in the General Manager's office, subject to revision by the rare resort of proceedings before the Railway and Canal Commission.

It need not surprise one that, as a result of this 
political interference, the railways in Germany show nothing like the progressiveness nor the efficiency that one would expect of a nation whose thoroughness and science are the admiration of the commercial world-a result which is sufficiently proved by the following figures :

(I) The locomotive equipment-surely a test of the adequacy of a railway as a moving machine-shows the following remarkable comparison : In Great Britian in 1895 there were 100 locos per IOO miles of railway ; in Germany only 59. The German equipment rose to 60 only in I900, while the British rose to rog engines for the roo miles.

(2) An examination of the movement of the capital expenditure on the railways in the two countries shown in the following table confirms the same conclusion :

British Railway Capital. German Railway Capital.

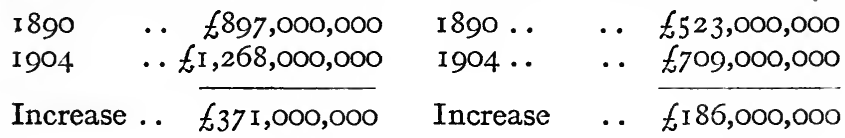

(3) Since 1875 the traffic per mile in Germany has increased from 4 IO, 000 tons to 740,000 tons only on the railways, while the corresponding increase on the waterways has been from 290,000 tons per mile to I, I 50,000 tons.

The case of the German railways has been selected to illustrate the inherent evils of State administration, not because Germany is a particularly bad exponent of bureaucratic organization. On the contrary, its officials are famous for their thoroughness, and it is for that reason, presumably, that Mr Lloyd George has held them up as ensamples; but other countries tell the same tale. The United States learnt her lesson in this matter in the 
hard school of experience fifty years ago. The following letter is quoted from the Philadelphia Evening Bulletin of the year I857, when that journal was urging the transfer to commercial management of the Pennsylvania Railroad, which was then owned and managed by the State :

'A well-managed Commonwealth never corrupts her children. Yet on Pennsylvania's public improvements thousands of employés have wrecked their characters, and hundreds of her most promising sons have had sad and real reason to curse the day they ever learned that Pennsylvania had a line of railroad or canal on which to seduce to crime. Under the necessarily loose and irresponsible mode of transacting business upon these works, this evil has been, and is being, done. While the works remain in her hands, they will be the home of partisans and swindlers, who will ruin themselves, disgrace the State, and spread a moral desolation among the people. Change of administration does not secure the evil. It is inherent in the thing, and will be manifested while human nature remains as prone to evil as at present.'

Severe as is this condemnation, it was fully adopted by the public opinion of America, and changes were introduced into the State constitutions which forbad any return to the fatal evil of public ownership.

A similar disfavour is overtaking the system in Belgium at the present day. The Revue Politique et Parlementaire concludes a detailed and able examination into the State railways of Belgium with the following words : 1

1 These admirable articles have been excellently translated, and are about to be issued as a pamphlet, by Mr. E. A. Pratt. 
' Incapable of assuring to travellers and traders the advantages promised at the time of the purchase; assailed by complaints touching alike the technical and the commercial operation of the State lines; incapable, also, of giving to the personnel of the railway a position equal to that which the companies' lines assure to their workers, the Belgian State has not been able even to draw from its railway system the financial results which the wealth of the country, the density of the traffic, and the possible economies in administration, should enable it to secure. ... The various defects which have here been narrated eventually reveal themselves: a centralization, and an amount of red tape altogether excessive; the want alike of initiative, of commercial instinct, and of a sense of responsibility to the different classes in the community; and an exaggerated intrusion of political and Parliamentary influences. The mediocre results, dissimulated under a system of inexact, if not fictitious, accounts, have long remained unperceived. The more recent Parliamentary discussions and documents have thrown a little light on the obscurity in which the railway administration loved to dwell, and the real position of the enterprise now appears much less favourable than one had so long supposed.

'Whenever, then, we are told-as we so often are-of the merits of State exploitation of railways, we ought not to accept those praises until we have gone into details. Belgium is a country where the system should have operated with the greatest chances of success; yet the results have been far from brilliant. One can hardly propose, in good faith, to hold up the management of the Belgian railways as an example to follow, when the persons affected by their operation raise against them such very vigorous criticisms. We commend to the partisans of State control in all things the following declaration by the President of the Brussels Chamber of Commerce: "Our Chamber does not regard with favour the way in which the railways are administered in this country; for if we compare what passes at home with what passes in surrounding countries, we see that we have much to learn in regard alike to our railways and to everything that is here administered by the State." ' 
Can anyone doubt that, if this is the result in other countries, to introduce railway affairs into the domain of politics in England would be not only to cripple the railways, but also to compel Members of Parliament to become more and more the bargaining tools of their constituents, and so (as Burke foretold) 'infallibly to degrade the national representation into a confused and scuffling bustle of local agency'? The recent interference of the Nationalist Members of Parliament to compel the employment of Roman Catholics on the staffs of the Irish railways is a sufficient indication of the kind of thing which might be expected.

Anything that should clip the wings of the railways would inevitably injure trade at large. The condition of the country before it had good internal communication shows-what, indeed, has long been known-that there does not exist any force so potent for good or evil in commercial economy as transport. In Great Britain the bulk of the trade is carried under special rates arrived at by special bargaining between the trader and the company. The Midland General Manager recently stated he had upwards of thirty millions of such rates. As we have seen, special rates are most difficult to obtain with national railways. What would their deprival mean to the course of trade here? Simply. that the free energies of the railway-man, co-operating with the trader in hundreds of millions of transactions every year, would cease to operate. What is the aim of the railway-men in exerting themselves in this way? It is to promote movement ; to find out a price at which 
business can be done; to fix terms as to credit, and so on, which can wisely be made, and so to generate traffic and to make commerce flow. How could State officials undertake such duties? They involve sagacity, initiative, zeal, commercial motive, spirit of adventure, traits notoriously absent from the official mind, and yet of vital importance to the promotion and maintenance of business. Commercial railways mean the continual removal of natural obstacles, until all districts of the country are brought into competition with each other as nearly as possible on equal terms, thus continually cheapening commodities and improving production. National railways mean the perpetuation of such obstacles in order to preserve what are called the geographical advantages of each district-in fact, commercial railways mean progress, national railways stagnation. Who can measure the difference?

But it is said the employés will be better off. Let us see. The labour market, like other markets, depends on demand. 'When two masters are running after one man it is good for labour.' Cobden said : 'When two men are running after one master it is bad for labour ', and all the laws in the world cannot alter that. What occasions the demand for labour ? Clearly the demand for commodities. That is increased by cheapness and reduced by dearness. The cost of transport enters into the price of everything. National railways mean fixed rates, dear transport, and therefore dear commodities. The labour market would be the first to feel the consequent reduction in demand. Another force which 
workmen rely on to keep up wages is the ultimate resort of a strike. But for a public servant to strike

- means rebellion. Even in democratic Australia the laws against strikes by railway-men are drastic. In fact, under national railways railway-men take a lower standing. They cease to be independent citizens (even losing the franchise in several democratic countries), and they exchange voluntary for compulsory labour.

There is yet another class to be considered - the owners of railway property. These might easily be better off than they are now. They have never had a reward at all commensurate with their splendid sacrifices, with the magnificent success of their adventure, and the immeasurable benefits which it has conferred on all classes of their fellow-countrymen. They have not even received the meed of public gratitude. On the contrary, their undertakings are exposed to the illnatured vilification of every ignorant busybody, and made the cockshy of every advertising politician, who, prevented by law from bribing his constituents out of his own pocket, now seeks to do so out of those of the railway shareholders. It would not be wonderful if a feeling should arise amongst railway proprietors that they have stood the sort of thing long enough, and that if the country did not know when it was well off, why should they teach it and suffer in the process? 'Let the nation pay us off ', they might say, 'and then we can invest the capital in some other country where it will be free from the danger of vote-catching politicians, whose pillaging hand knows no restraint either of justice 
or patriotism.' Railway-men are called upon by the chivalrous duty which they owe to these proprietors, the bulk of whom are holders of only small sums, often the investment of hard-earned savings, and the sole stay of the widow and the orphan, to make a firm stand against this unsound and discreditable tendency of the public mind to oppress railway property. We should do our part to form an honest public opinion, and to awaken the conscience of the country to realize that justice, after all, is the greatest interest of a nation.

The more you examine these projects of State industry, the more do their conditions appear to offend against the genius of Anglo-Saxon institutions. Whatever may be the prizes of such schemes, depend upon it, they are not for America and England. Other nations, trained through the practice of many generations to a system of centralized control, so that each man takes his rank subordinated in its due place to his superior, may through that system manage their general domestic affairs well enough; but place them in a situation where they have not the accustomed formation to support them, and where are they? The repeated failure of their colonizing schemes is a sufficient answer. It is because our Anglo-Saxon race has steadily resisted such artificial aids, and has looked on the State as a mother to honour and to work for, and not a cow to suck at, has brought up its children in habits of self-reliance, independence, and individual strength of character, that it has been given to us as to none other of the sons of Adam to lay hold upon that high inheritance of man, 'to possess the earth and subdue it.' 


\section{CHAPTER XVII}

\section{CONCLUSIONS}

T $\mathrm{T}$ is a custom honoured amongst the legislators of 1 Great Britain, in circumstances affecting the safety of the Empire and its fighting forces, to set aside party differences, and to discuss the various aspects of the matter in hand free from all political bias. I have endeavoured to show that municipal trading, like a worm in the bud, is endangering the fairest evidence of Great Britain's greatness-the justice and happiness of its citizenship. It seems appropriate, therefore, to plead that the testimony here brought together may be examined in a judicial attitude, and with the determination that there shall be an end to the misfortune which to-day has to be recorded in British history-that municipal elections are fought on political party lines. Manifestly, until that evil is stamped out, corruption will breed corruption; for, although the present injury is, for the moment, most conspicuous in regard to local councils, it will inevitably react upon the constitution of Parliament itself, culminating in collusion between those who judge and those who are judged. If Parlia- 
ment is to maintain its position as the ultimate tribunal, it must stand aloof from parochialism; and if citizens are to retain their place in the development of townships and of country districts, each man working out his individuality, this product of modern hustling - the political municipal election-must disappear. There are indications that the seriousness of the issue which I have presented, or, at all events, the inconveniences that arise from neglect of it, are now more widely recognized. Moreover, protests against fighting municipal elections on party lines have been uttered by representatives of both extremes of political life. It is to those who share in this view that the arguments contained in this book will, it is hoped, be most useful.

Any endeavour to treat the matter judicially would have to begin by defining, if possible, in how far it is, or is not, desirable to introduce State or municipal control of public services. The time has obviously gone by for the navy, the army, and the police to be managed by private enterprise. Their organization has become, as it were, part of the British Constitution. Again, the postal service must clearly be admitted to be past discussion in this regard ; and it is probable, in spite of the large financial losses-partly due to the political popularity of the 'sixpenny telegram '- that the inland telegraphs may be included in the same category. Watersupply may be considered as being on the border-line in Great Britain, but in America it has long been a settled public policy that water-supply should be con- 


\section{I2 THE DANGERS OF MUNICIPAL TRADING}

trolled by municipal bodies or by commissions appointed by the different States.

The parting of the ways clearly comes when the advocates of municipal or State socialism begin to regard the railways as next on the list towards communism. For example, it is urged by some that moderate control of railways in India might be accepted as part of a military system. Here we are on dangerous ground, for the acceptance of this might ultimately lead to the absorption of the entire railway system by the Government, which could not fail to end disastrously. In case of war, the fact that the railways are in private hands is of little consequence, for the Government can use them, defend them, or destroy them, if necessary. State control of railways is wise, and in Great Britain railway companies have been from the beginning under wholesome and reasonable control. In America the early control was neglected, because States, counties, and municipalities were all striving to secure railways, and were willing to offer private capital extraordinary inducements to build them. The American railway system from its birth was subject to little or no control from any authorities. Many of the subsequent defects and much of the present trouble may be traced to this. Taken, however, as a whole, the railway systems of Great Britain and the United States are splendid examples of individual initiative. The exercise of reasonable governmental cortrol, President Roosevelt recently said, will 'not do away with the freedom of individual initiative or dwarf individual effort.' I 
believe with him that it would be a veritable calamity to fail to put ' a premium upon individual initiative, individual capacity or effort; upon the energy, character, and foresight which it is so important to encourage in the individual.'

There is a vast difference between the conduct of the business of the nation by the Government and the exercise of such control or supervision by the Government as will ensure that affairs are being conducted in the interest of the nation. The failure to note this distinction has seriously injured Mr Bryan's chances in the next Presidential campaign. The declaration of this statesman on his return home last August that he favoured State ownership of railways for the United States created something akin to a panic in the political party to which he belongs. His subsequent explanations and modifications of the original speech have not allayed the alarm occasioned by the declaration. Only a few days ago Mr Culberson, United States Senator from Texas, though an admirer of Mr Bryan, and of the same political faith, said in an address before the State Legislature of Texas: ' I cannot conceive that his (Mr Bryan's) views on this question will ever receive the approval of the democrats of the country. No ; the doctrine of Government ownership and operation of railroads is, in my judgment, paternalistic, impractical, and undemocratic. It will create millions of additional offices. It will put billions of property, which will increase each year, under political management. It increases every character of railway expense. It 


\section{I4 THE DANGERS OF MUNICIPAL TRADING}

will make every question of railroad construction or extension political and partisan, in which the South, mark you - the South-undeveloped and in the minority, will especially suffer.'

The Governmental ownership of railways, both in the United Kingdom and in the United States, would be very undesirable. There are many abuses, some of them, in the United States, grave abuses, that will be remedied ; but this can all be accomplished with adequate and reasonable control. This volume has not attempted to deal exhaustively with these larger questions of Governmental ownership, but, with the exception of Chapter XVI., on the 'Nationalization of Railways', has in great measure been confined to municipal affairs. I have shown that municipal bodies have extended their prerogatives towards a multiplicity of interests and commodities, ranging from milk-supply to steamboat proprietorship, and from road locomotives to music-hall surveillance. The question that has first to be answered is, Where should the line be drawn?

It is hoped that the foregoing review of the present meaning of municipal trading may afford the means of demarking simply and clearly the proper distinction between what might with advantage be subjected to municipal control and what ought to be left free for private traders. The main criterion in any particular case should be, Can the commodity or service be worked efficiently on competitive trading principles? If this can be done, there should be no hesitation about handing it over for private contract; for competition is the 
life of commercial progress, and monopoly-above all, municipal monopoly-its most dangerous enemy. Those industries which cannot so well be operated on competitive lines, such as tramways, gas, electric light and power supply, should be controlled, but not, in my opinion, operated, by the municipal authorities. This procedure, if wisely enforced, will give to the community its just share of all the benefits, both in revenue, in relief of taxation, and in reasonable and efficient service. It leaves the individual free to assume the financial responsibility and to reap equitable reward for management and operation.

In an ideal world, where each man's good was each man's rule, municipal trading would probably be largely extended. These conditions do not exist in either British or American municipalities, and therein lies the danger of these experiments. In the United States it would make conditions infinitely worse than they are; in Great Britain, if persisted in, it will lower the standard of municipal government. Socialism and political partisanship cast their shadow on the whole problem, so that, blinded by self-interest and transient benefit, the voter allows himself to be led into a system which in the end means the subversion of individuality, the ruin of the community, and the degeneration of all concerned. 



\section{N DEX}

Accoontancy, N.S.W., 7I

Act, Electric Lighting, 5, 2I I, 216

Electric Power, 219

Light Railways, 199

Public Authorities Protection, 208

Public Health, 128

Telephone, 233, 234, 337

Tramway, I37, I92, I93, 204

Working Class Dwellings, 26I

Acts, Early Closing, Ioo

Administration, Local, British, 2 ; American, 3

Alverstone, Lord, rog

Association of Municipal Corporations and Town Clerks, Io, 109

Avebury, Lord, 94

BALFOUR, Mr A., 85, 88; $\mathrm{Mr}$ G., 97

Beaulieu, M. Leroy, I30

Bemis, Mr, 25

Bethell, Mr U. N , 247, 250

Birmingham Daily Post, 272

Board, Metropolitan Water, 132 of Trade, the, 298, 301

Book, origin of the, $v$

Booth, Mr Charles, I55

British Electric Traction Company, r8I

Broodbank, Mr J. G., 149

Bryan, Mr, 36, 285, 313

Burns, Mr John, 12, 83, 136, 236
Chamberlain, Mr. Arthur, I7I

Chaplain, Mr, 206

Cities, solvency of, 153

Collins, Mr Edward, 26I

Conclusions, 3 II

Constitution, Australian, 59

Contemporary Review, I07

Cornwall, Sir E., r 35

Council, London County, 8, ro, $49,82,95,99$, Ior, I3I, I4I, I43, 145 , I55, I57, I74, I77, $209,225,228,260$, 275; and Borough Councils, I43, I46

Willesden Urban District, 222

Credit, definition of, 153

Culberson, Mr., 313

Daily Chronicle, The, 230

News, The, 95

Telegraph, The, 162

Dalrymple, Mr (Glasgow Municipal Tramways), I5

Darwin, Major L., I50

Davies, Mr Dixon H., x, 7, 22, $32,94,125,133,235$

Debt, Municipal (see Municipal),

National : Russia's, 53 ; Australia's, 57, 64, 65, $66,67,70,74$; New Zealand, 64

Debts, comparative statement of

National, 64, 65, 66

Doctor, 287 
Eastern Morning News, The, 242

Edge, W. H., 286

Electric Light Company, Newcastle-on-Tyne, 221, 227

Electric lighting, 27, I45, 182, 2 I2

Supply, 34, III, I4I, I56, I8I, I89, 2II, 226

Electrical industry, strangling of the, 2 II

Electrical Review, The, 240, 242

Electrical undertakings, cost of, $104,145,218$

Engineering, 140, I79

Fabianism and the Empire, 48

Fortnightly Review, The, I22, 172, I 85

GARCKE, Mr E., 197, 205, 220

Gas Lighting Association, 42

Giffen, Sir Robert, I07

Gorky, 50

Gray, Mr Albert, 206

Great Central Railway Journal, 285

HARDIE, Mr Keir, 93

Hill, Miss Octavia, 277

Hodgson, Mr William, 224

Housing by Voluntary Enterprise, 259

Howe, Dr F. C., I8

Imperial INDUSTRIES Club, 83 Industrial Freedom League, Io Interstate Commerce Commission, 296

Labour Party, Australian, 59 Lancashive Post, The, II 8

Lawrence, Hon. Charles N., 83

Lefevre, Mr Shaw, I93

Lloyd George, Mr, 298, 303

Local Authorities, extravagance of, $x_{57}$ personnel of,
London Argus, The, 153, 154

London Municipal Society, I6

Traffic, Royal Commission on, $11,206,262$

Long, Mr R. E. C., 92

MARRIOTt, Mr J. A. R., I72

Martin, Rudolf, $5^{I}$

Mill, John Stuart, 8r, 84, 88

Morning Post, The, I75

Municipal and private enterprise, III, 157, I66, 184, 188, 198, 258, $270,276,315$

Debt: British, II2, II8, I28; London, I3I, I46; United States, II3

Employé, the, 89

Expenditure, British, II8, I23, I3I ; London, 156

Gas Works, 34, 188, 212

Housing, 258 ; Birmingham, 27x, 272 ; Glasgow, 270 ; Leeds, 273 ; Liverpool, 272 ; London, I 4 I, 259, 260, 274, 283; Manchester, 269

Socialism, 6, 9, 45, $5 \mathrm{I}$, 57, 6I, 77, 79, 89, 9I, I08, I43, I70, $225,228,271,278$, 283,315

Trade, 150

Trading Committee, 8

Trading, common sense of, vi, 143, I69, 170, 204, 267, 268, 269; general case against, $2 \mathrm{I}$; in Australia, 37, 44, $56,69,79$, 100 ; in Birmingham, 5, 95; in Chicago, 15, 19, 49 ; in Glasgow, 15 , 19, 92 ; in Russia, 
$37,44,56,79,8$ o, $89,100,103$

Tramways, 33, 126, 136, 173, 178, 188, I9I, 198

Waterworks, 33, 116 , I33, I 88

Year Book, II3, II8, I 88,269

Municipalities and accounts, 167 , 178, 183, 249; and employment, 96, 277 ; and finance, I 58, I 67, I 84,231 ; and profits, 167 , 178, I89, 214, 222, 242,246

and their neighbours, 262,250

Municipality as an employer, the, 85

Murphy, Mr William, 3I

National Civic Federation, i 8 National questions, Australian, 76

New York Governorship (Mr

Hearst), I9

Officers, Municipal, 103

Omnibuses, motor, 208, 2 IO

O'Sullivan, $\mathrm{Mr}, 68$

Ownership obligations, burden of, II 2

Parsons, Mr James, 259

Pensions, Australian State, 6I ; English, 66, 99

People of London, Life and Labour of the, I55

Philadelphia Evening Bulletin, 304 Political Economy, Principles of, 81 Poplar Board of Guardians, 107 Post Office as a model, the, 289

Private traders, the duty of, 42

Progressives $v$. Moderates, $15 \mathrm{I}$

Public Works, Australia, 56 ; N.S.W., 69
RaIlway, Great Central, 29r

London and South. Western, 299

Midland, I24

North-Eastern, 208

Railway labour, condition of, 307

strikes, 308

Railways, American, 292, 312

Australian, 293

Foreign, 294, 299

Nationalization of, 285,3 I 2, 3I 4

Taxation of British, 126, 149

Reeves, Mr W. Pember, 68

Reflections of other minds, 78

Revue Politique et Parlementaire, 304

Road-making, Foreign, 290

Roderick Random, 287

Rollit, Sir Albert, 9o

Russia and Japan, future of, 5 I

Schooling, MR J. Holt, 122, $184,185,186,187$

Shaw, Dr Albert, I3

Mr G. Bernard, v, 29, $48,55,80,8 \mathrm{I}, 83, \mathrm{I} 42$, I57, I69, I70, 203, 266, 278

Sims, Mr G. R., I57

Socialism (see Municipal Socialism)

Socialistic Party, Anti-, Australian, 60

Spencer, Herbert, 80, 88

Spendthrift, the world's greatest, I3I

Standard, The, ro8

State Convention, Massachusetts, 22 ; Michigan, 23

Statesman's Year-Book, The, 249

Statist, The, $16_{4}$

Steamboats, Thames, 49, ro4, I 35

Sydney Bulletin, 71, 72, 74

Sydney Morning Herald, 75 
TAxation, growth of, I2r, I29, I47, I5O, I54; in Battersea, 147 ; in Poplar, 148 ; in West Ham, I49, 154

Telegraph Systems, American, 247; British, 27, 244; Continental, 248

Telephone Company, National, 233, 237, 246, 256

Telephones, 35: American, 253 , 255 ; Continental, 250 ; Glasgow, 238; Hull, 24I; London, 233, 24I, 246, 256; Municipal, 232; Tunbridge Wells, 237; various cities, 254

Temps, Le, 53

Thatcher, Mr John Boyd, 78

Thompson, Professor Silvanus, 226

Times, The, 7, 9, 17, 96, 97, 99, 107, I36, I41, I50, I 52, 218 , $236,260,265,271,278,283$; Engineering Supplement, 197, $205,220,256$

Tolstoy, 50

Town clerks, position of, 40, IO4

Traction and Transmission, 9

Trade activity, Australian, 63
Tramway Tangle, the, rgr

Tramways and street widening, I74

Glasgow, I79

Hyde, 199

London County Council, I40, I45, I74, I77

London United, I74, 180

North Metropoli$\tan , 137,177$

Transport, early, 286

Tribune, The, 29, I49, 157

UNEMPLOYed, Australian, 67; English, 97, 277

Von Miguel, Herr, 295

Webb, Herbert Laws, 236, 256

Welby, Lord, 134

Witte, Count, $45,47,48,54,80$, $8 \mathrm{I}, 100$

Wolcott, Governor, I4

Yorkshire Post, 273

THE END 



UNIVERSITY OF CALIFORNIA LIBRARY

THIS BOOK IS DUE ON THE IAST DATE STAMPED BELOW

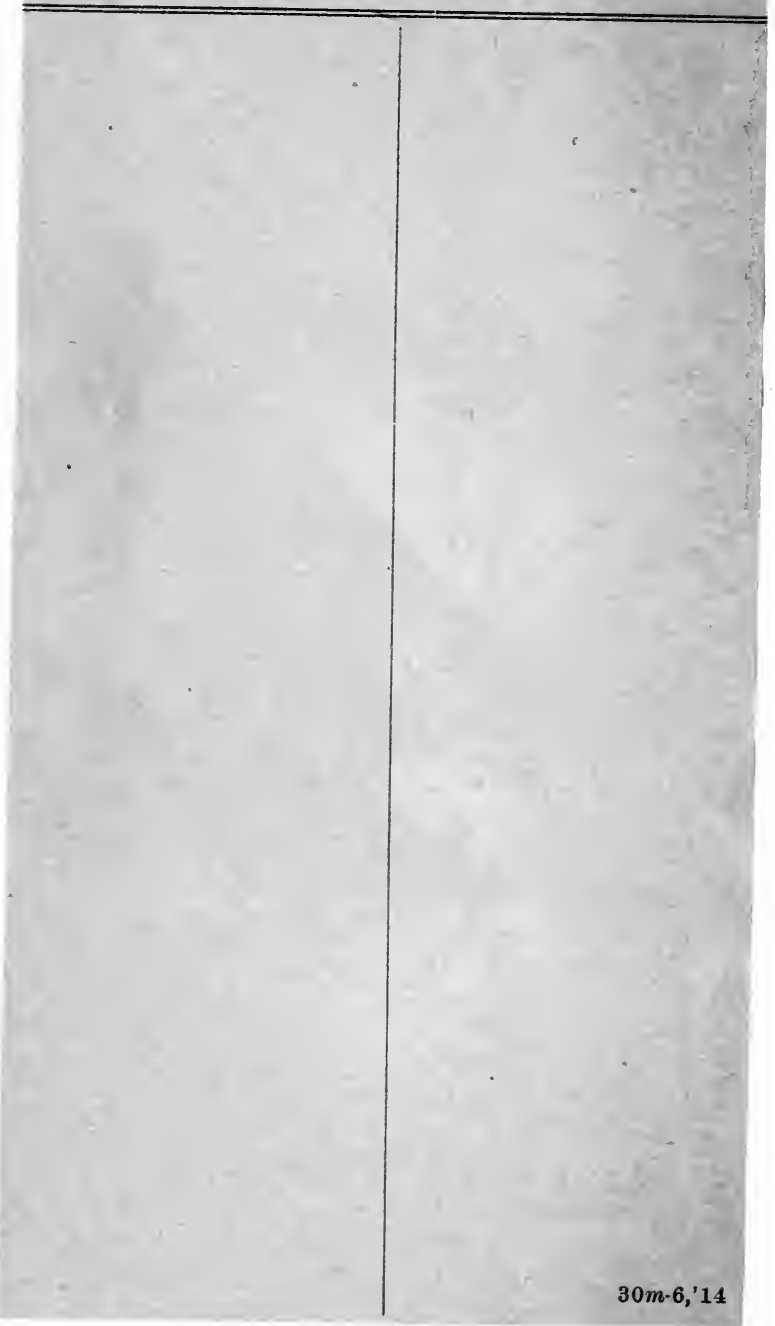


YB 19280

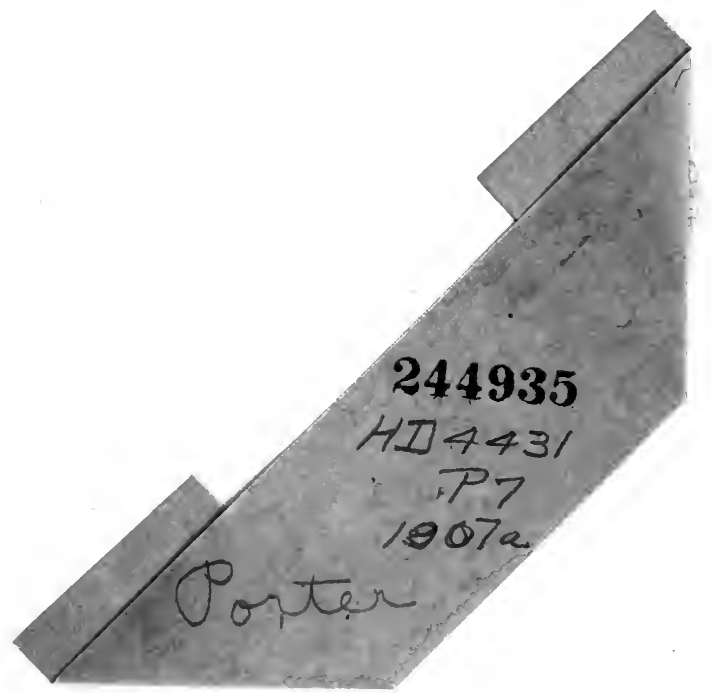


